
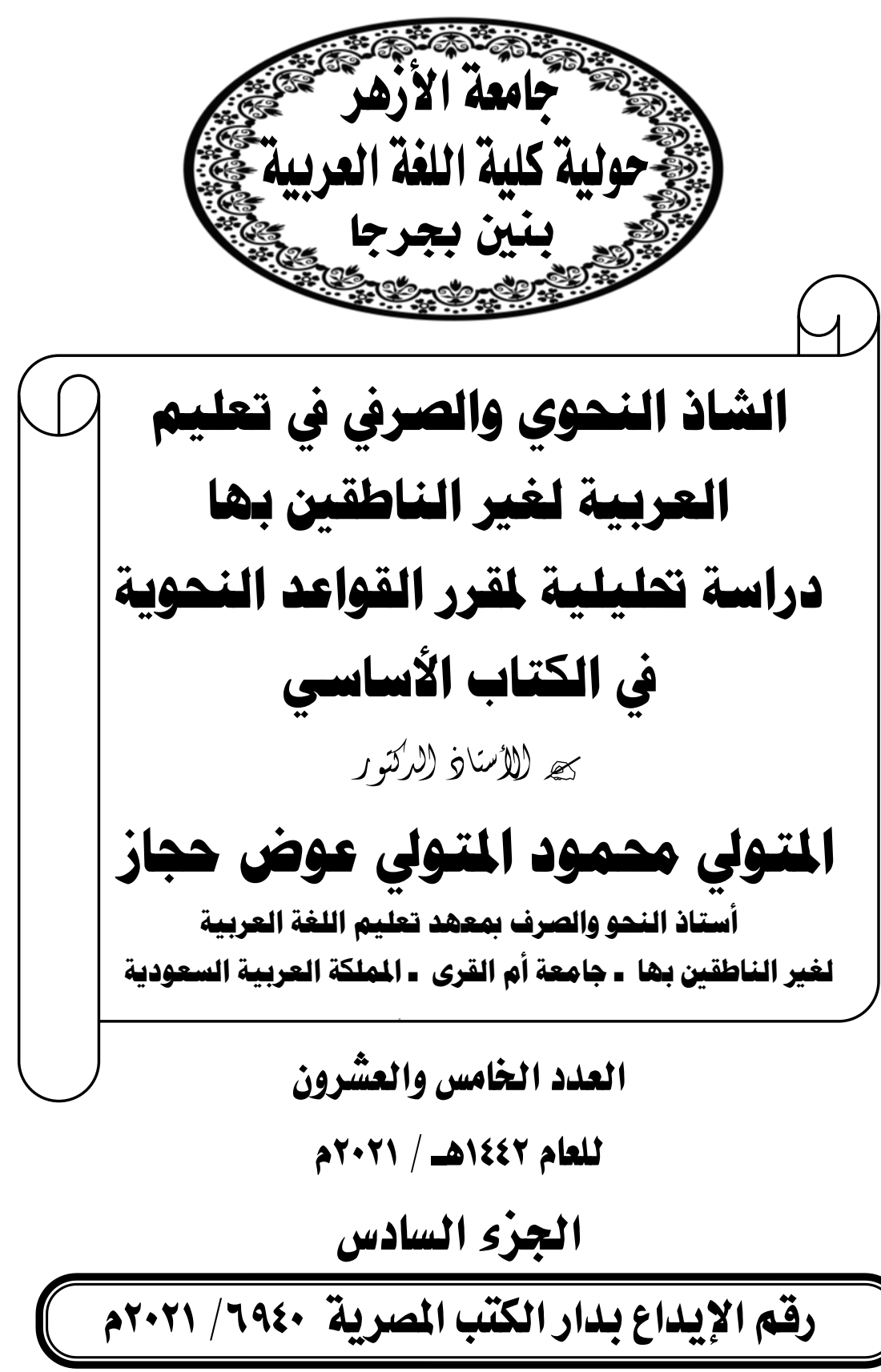

0

ISSN 2356-9050 الترقير الصولال

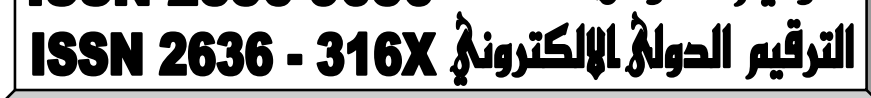



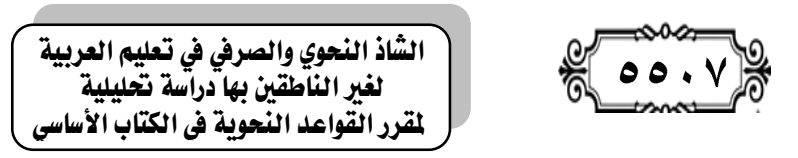

العدد الخامس والعشرون للعام الجزمبام السادس

هִنـ

الشاذ النموي والصرفي في تعليم العربية لغير الناطقين بها

دراسة تهليلية القرر القواعد النحوية في الكتاب الأساسي

الإتولي همثمود الإتولي عوض دوف هماز

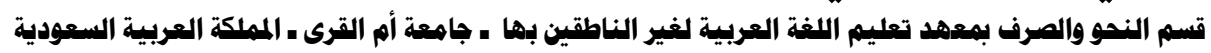
me-1965@hotmail.com : البريد الإلكتروني

\section{: صناll|}

اهتمت الدراسة بالتأصيل الصحيح للارس النحوي والصرفي للطلاب غير الناطقين بالعربية، وتصويب مقولة: أن النحو مشكلة ومعضلة في ذاته، وتدعم القول

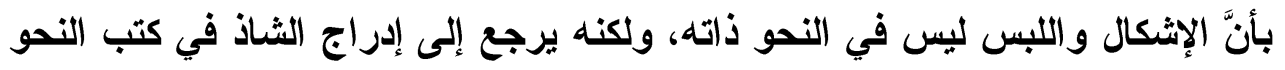

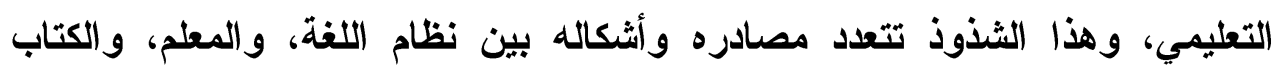

$$
\text { التعليمي، والاختبار ات، و التدريبات... إلخ. }
$$

وقد آثرتُ دراسة الثاذ النحوي والصراتوفي في كتاب رائد في مجال تعليم العربية

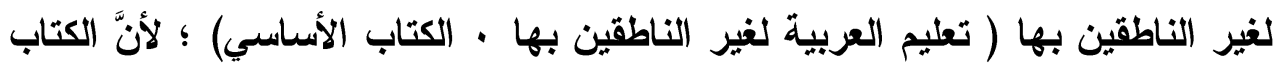

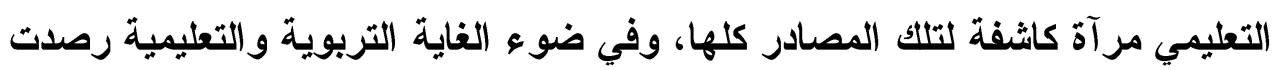

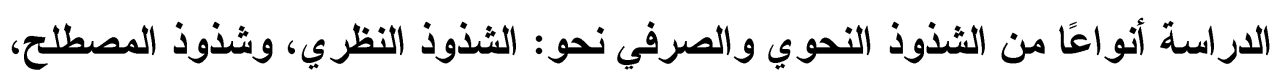

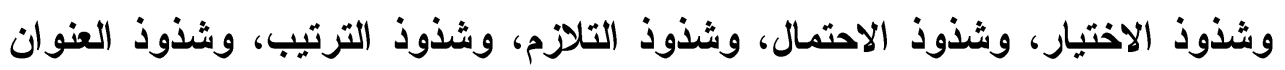

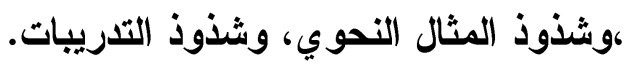

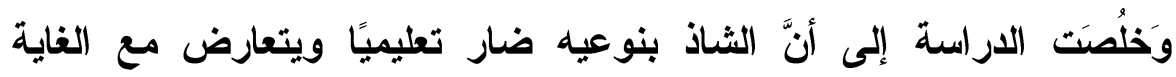

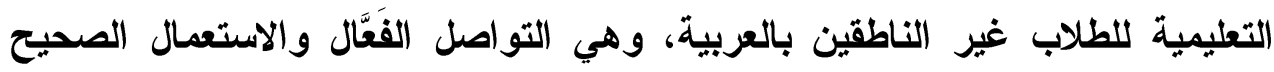

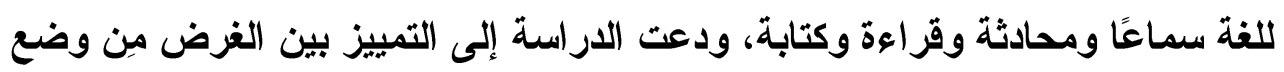

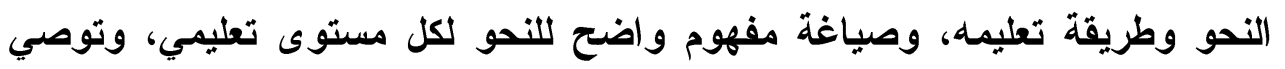

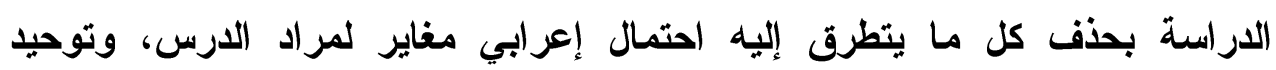

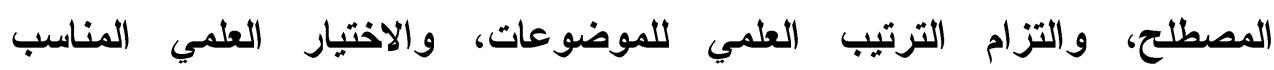
لموضوعات كل مستوى تعليمي، والتزام نمط علمي واحد في العناوين، وتناسب

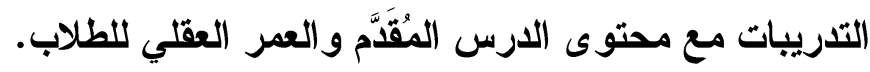

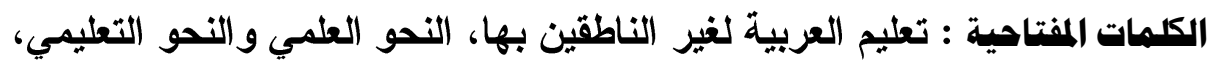
الثاذ النحوي والصرفي تعليميًا.

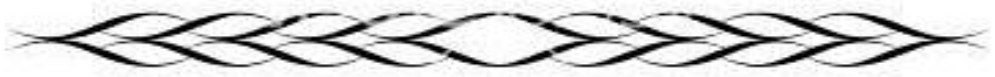


الترقير الدولخ 2356-9050 235

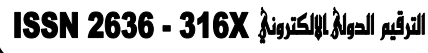

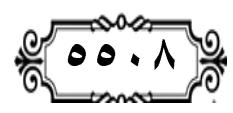

حولية كلية اللغة العربية بجرجا

مجلة علمية مجكمة

Abnormal Grammar and Morphology in Teaching Arabic for NonNative Speakers Analytical Study of The Course of Grammar Rules in The Basic Book

Al-Mitwali Mohamoud AL- Mitwali Awad Hejaz

Department Grammar and Morphology at the Institute of Arabic Language for Non-Native Speakers - Umm Al Qura University

Email: me-1965@hotmail.com

Abstract

The study focused on the correct rooting of the grammar and morphological education for non-native speaking students, and correcting the saying: Grammar is a problem and a dilemma in itself. The study also proved that the problematic and confusion isn't in the Grammar itself, but due to insertion the abnormal in educational grammar books. And this abnormality has multiple sources and forms between language system, teacher, book, tests, and exercises Etc.

I preferred to study the abnormal grammar and morphology in a major book in the field of Educating Arabic for Non-Native Speakers; as the educating book considered as a revealing source for all these sources. In view of educational and learning goal, the study detected types of grammar and morphology abnormality as: theoretical abnormality, term abnormality, choice abnormality, possibility abnormality, correlation abnormality, ranking abnormality, title abnormality Example abnormality and exercises abnormality.

The study concluded that the abnormal with its two types is educationally harmful and contradicts the educational goal for nonnative speaking students of active communication and correct using of language in listening, speaking, reading and writing aspects. The study called for distinguishing between the purpose of developing grammar and its teaching method, and formulating a clear concept of grammar for each educational level. The study recommends deleting everything that deals with the possibility of expressing a different synonym for the purpose of the lesson, standardization of the term, commitment to the scientific arrangement of subjects, the appropriate scientific choice of topics for each educational level, and the commitment of a single scientific pattern in the titles, and the exercises must fit with the content of the presented lesson and the mental age of students.

Keywords : Teaching Arabic for non-native speakers - Scientific grammar, - Educational grammar - Abnormal Grammar and Morphology Educationally 


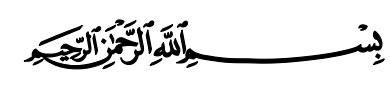

\section{مقدمبة}

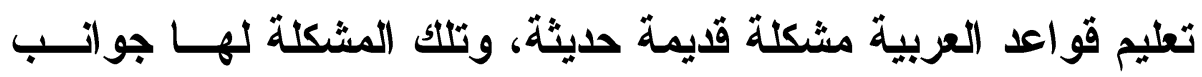

شتى، منها ما يتصل بالكتاب التعليمي، ومنها ما يتصل بالمعلم، ومنهـــا مـــا يتصل بالطالب، ومنها ما يتصل بالظروف والملابسات المصــاحبة للعمليـة التعليمية، وأحسب أن أكثر هذه الجوانب خطورة ما يتصل بمـنـهج الكتــاب التعليمي المقدَّم للطلاب عامة وللطلاب غير الناطقين بالعربية خاصة. ومن خلال تجربتي الأكاديمية في تلريس النحــو والصــرف للطــلاب العرب في كلية اللغة العربية، وتدريس كتاب (تعليم العربية للناطقين بغيرها. (الكتاب الأساسي) في معهد اللغة العربية لغير الناطقين بها لأكثر من خمسة

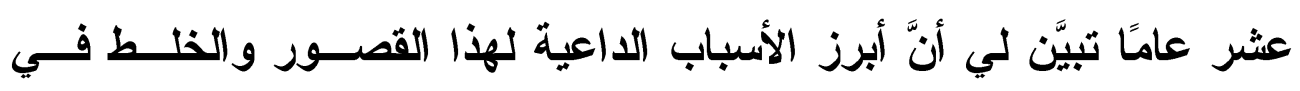
تصنيف الكتاب التعليمي لغير الناطقين بالعربية ثلاثة: أولها: عدم التحديد الاقيق للمستوى التعليمي المــراد تلدريســه لغيـر

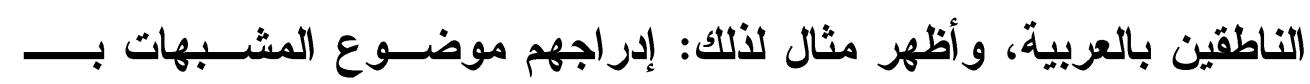
(ليس)، وموضوع (الاثتغال)، وموضوع (الصفة المشبهة باســم الفاعـلـ) ونظائر ها في كتب تعليم العربية لغير الناطقين بها. وأمـا الثاني: فقضية الخلط في تحديا ماهية النحــو المُقــَّم لهــؤلاء الطلاب ووظيفته.

وأما الثالث: فيتمثل في الخلط بين النحو العلمي والنحو التعليمي. ولهذا شرعت في هذا البحث الموسوم بـ (الثشاذ النحويـوالصــرفي في تعليم العربية لغير الناطقين بـها. دراسة تحليلية لمقرد القو اعد النحويــة في (الكتاب الأساسي). 


\section{أهميية الدراسة:}

تسهم هذه الدراسة في تقديم نقد بناء لموضوعات المقررات النحويــة

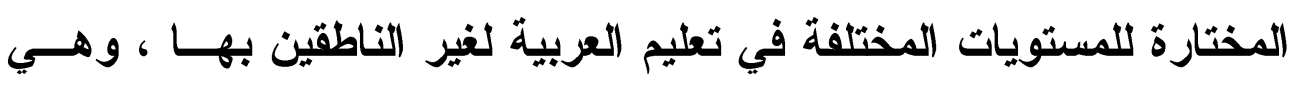

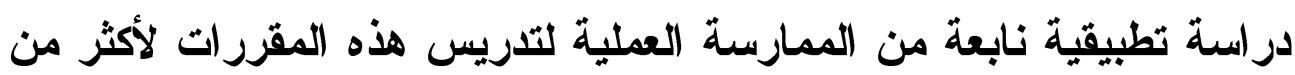

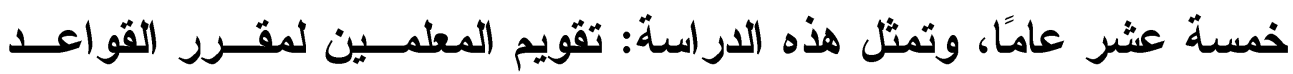

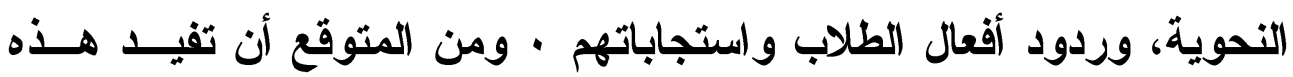
الار اسة المؤلفين ومعلمي العربية لغير الناطقين بها. هشكلة الدراستة:

تنبع مشكلة هذه الدراسة من الفجوة بين التنظير والتطبيق في مجـال التأليف لتعليم العربية لغير الناطقين بها، فعلى حين تكثر الدراسات التنظيرية

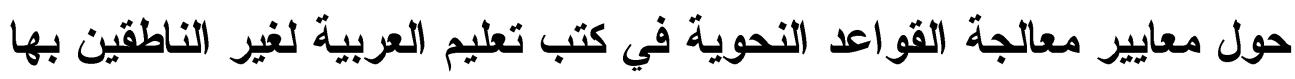

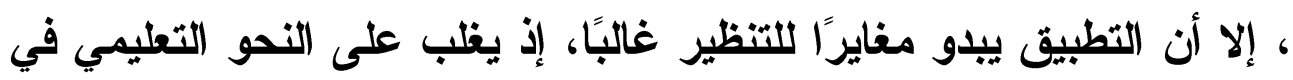

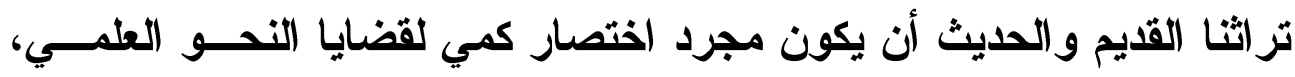

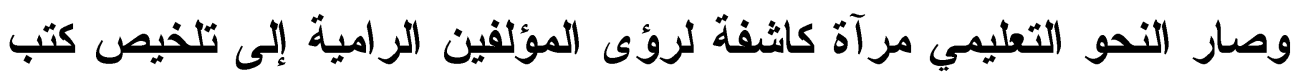

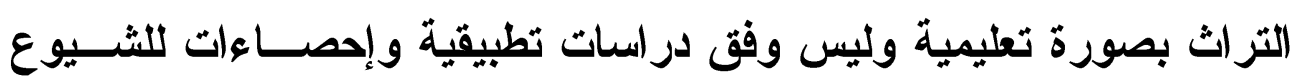
و البساطة ....إلخ ، وتلك المشكلة تم تناولها من خلا وله الأسئلة التالية: 1 - ما ماهية النحو المُقدَّم لغير الناطقين بالعربية ؟ وما وظيفته؟ r- ما النحو العلمي؟ وما النحو التعليمي ؟ وما معايير التزاكيب النحوية في كتب تعليم العربية لغير الناطقين بها؟ وما؟ r- ما الثناذ النحوي و الصرفي تعليميًا؟ ع - ما أنواع الثذوذ النحوي والصرفي في الكتاب الأساسي؟ 
1- التعريف بماهية النحو المُقدَّم لغير الناطقين بها ووظيفته . r بيان أن قواعد الإعراب علم بكيفية كلام العرب وليس هو اللغة والكلام نفسه .

r- الإقرار بأن النحو العربي مرجع لما يجوز ولا يجوز من كــلام العـرب وليس طريقة تعليمية.

ع - الكثف عن الحقيقة الثابتة في الأذهان الغائبة في التطبيق العملي، وهي

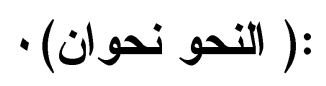

ه- بيان أن الثذوذ في النحو والصرف التعليمي مجانب ومجــافٍ لطبيعـة

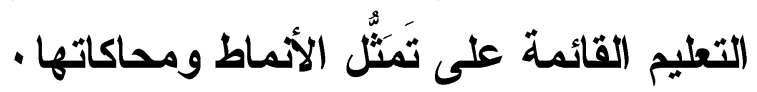

צ- الوقوف على أنماط وأنواع الثذوذ النحوي والصــرفي والــــوة إلـى تجنبها في كتب تعليم العربية لغير الناطقين بها.

\section{حدود الدراسة :}

تقتصر هذه الدارسة على كتاب ( تعليم العربية لغير الناطقين بهــا -

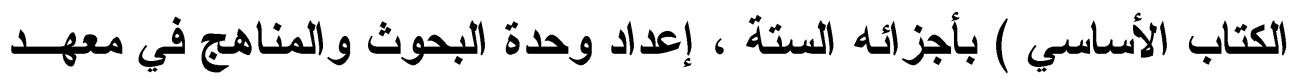

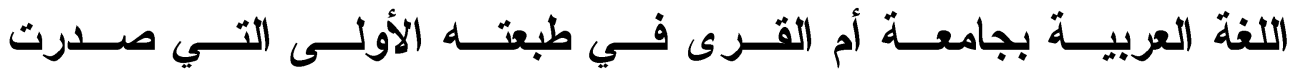

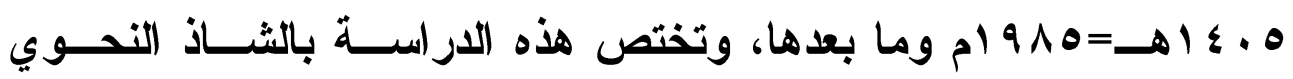
والصرفي في مقرر القواعد النحوية في الكتاب الأساسي دون غيــره مسن فـن الكتب المساندة في هذه السلسلة . 


\section{هنهج الدراسة : من}

هذه دراسة وصفية تحليلية تقويمية لمقرر القواعد النحويـــة بالكتــاب

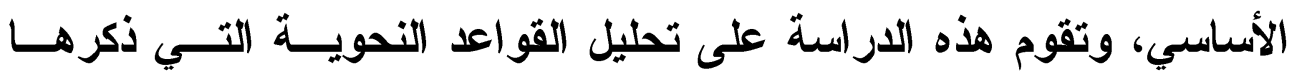

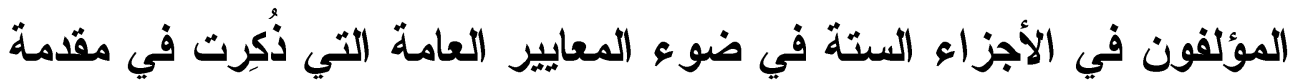

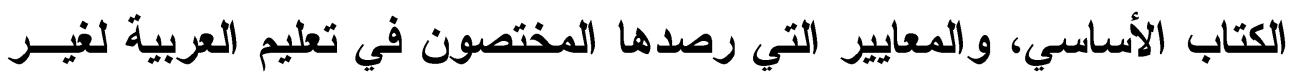
الناطقين بها ؛ لمعالجة القواعد النحوية في كتب تعليم العربية لغير الناطقين

بها

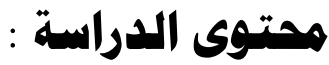

تحتوي هذه الاراسة على جانبين أولهما: المقدمة ورواقدها ، وفيـهـ

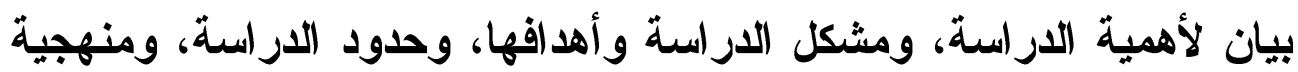

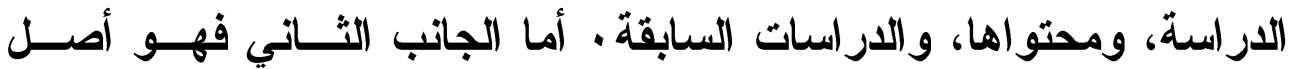

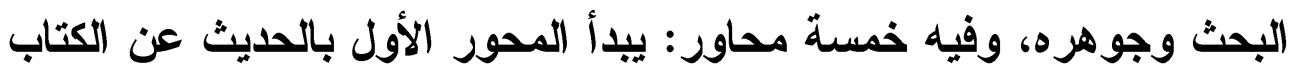

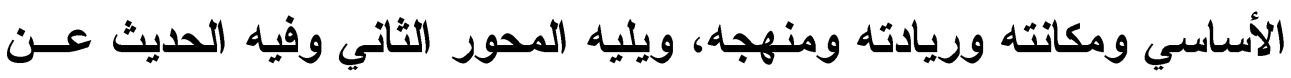

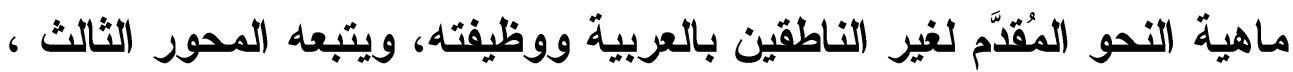
وفيه بيان للفرق بين النحو العلمي والنحو التعليمي، أما المحور الرابع ففيه

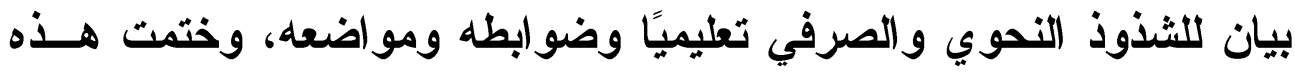

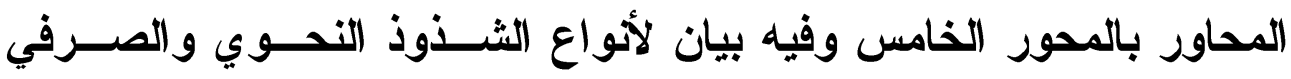
التسعة التي رصدتها الارسة، ثم خاتمة الدراسة وفيها رصد لأهم النتائج .

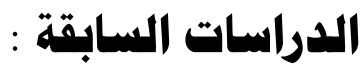

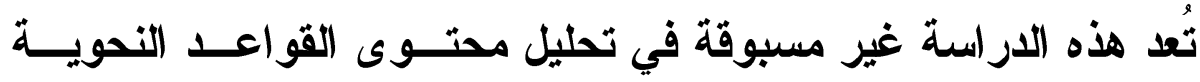

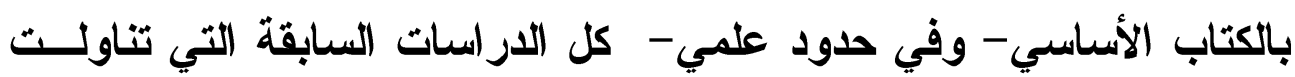


الكتاب الأساسي أو القواعد النحوية فيه دراسات عامة للمعاييز ، ولم أجـــ أي دراسة للثاذ النحوي والصرفي تعليميًا في كتب تعلـيم العربيــة لغيـر الناطقين بها عامة، وفي الكتاب الأساسي خاصة ، وفي هذا السياق أثــير إلى نماذج من الار اسات السابقة ، وهي:

ا - ( تقييم الكتاب الأساسي لتعليم اللغة العربية لغير النـاطقين بهــام) د

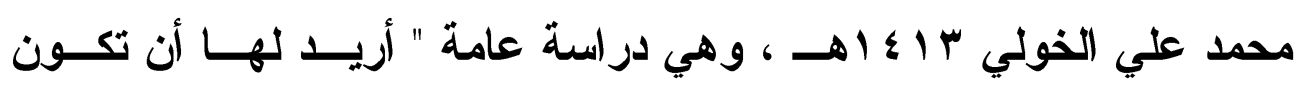

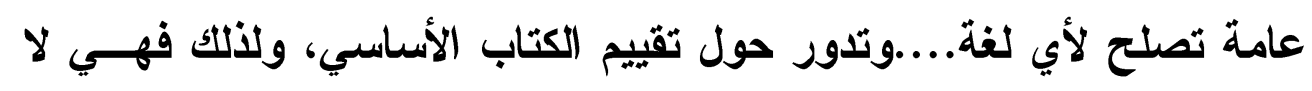
تركز حول تقييم مهارة بعينها ....وتهاف....إلى اختيار أهم المعـايير دون الاخول في تفاصيل"(1) r - ( معالجة القواعد في كتب تعليم العربية لغير الناطقين بها) د فيشر ، وهي در اسة جادة في طريقة معالجة القواعد في كثب تعليم العربيـــة لغيـر الناطقين بها ،إلا أنها اهتمت بذكر بعض المعايير العامة دون تطبيقها علــى دهى كتاب بعينه - ne

r- ( الكتاب الأسـاسي لتعليم اللغة العربية للناطقين بغيرها . مواصــفاته

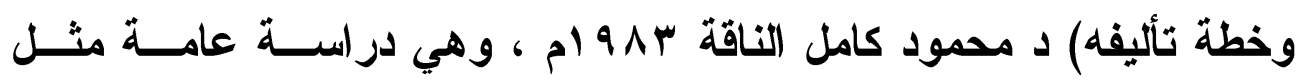
الار استين السابقتين وتخلو من التطبيق ع - ( معايير اختيار التزراكيب النحوية في كتـب تعلـيم اللغـــة العربيــة للناطقين بغيرها ،در اسة تطبيقية على كتاب الطالب من سلسلة العربية بين يديك ) د محمد عبد النور محمد الماحي 10 ـ بام ، وهي دراســة لمعـاييز اختيار التراكيب النحوية في كتاب آخر هو: ( العربية بين يديك) ، ومع أنها در اسة تطبيقية ، إلا أنها خلت من أي ذكر للشذوذ النحوي والصرفي. 


\section{أولاً : كتاب (تعليم العربية لغير الناطقين بهاد). الكتاب الأساسي):}

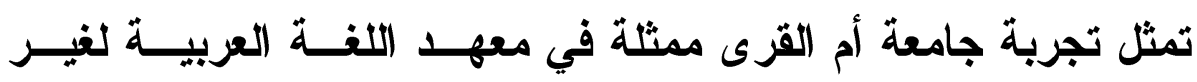

الناطقين بها في تأليف الكتاب الأساسي لتعليم العربية لغير النــاطقين بهـــا تجربة رائدة في مجالها على الرغم من مرور أكثر من ثلاثين عامتَـا علــى

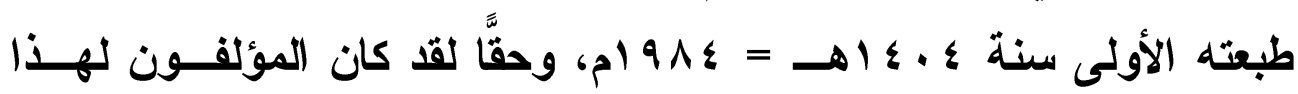

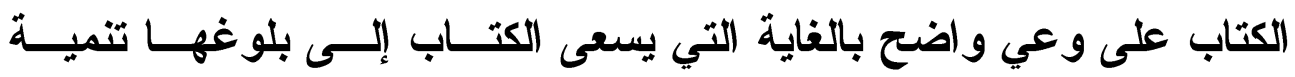
للمهار ات اللغوية المختلفة من الكلام والاستماع والقراعة والكتابة، وكانــــ

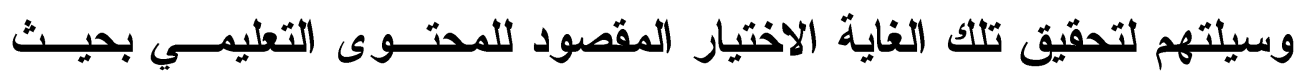

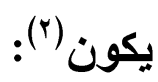

(1) مصطلح (تعليم العربية لغير الناطقين بها · الكتاب الأساسي) اختاره المؤلفون عنوانًا لهذا

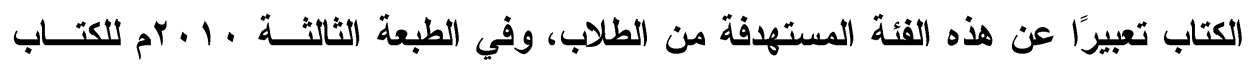

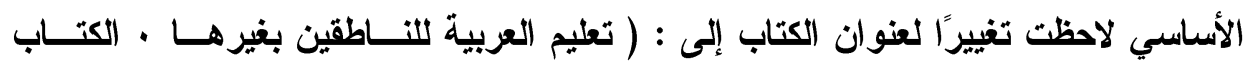

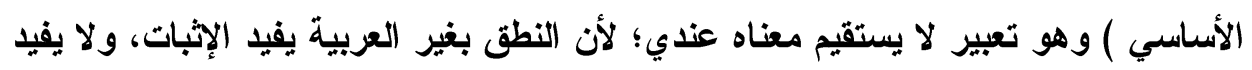

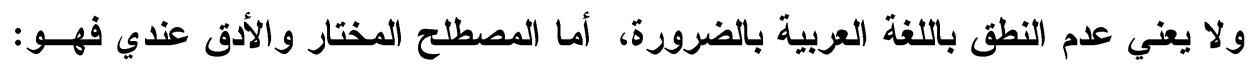

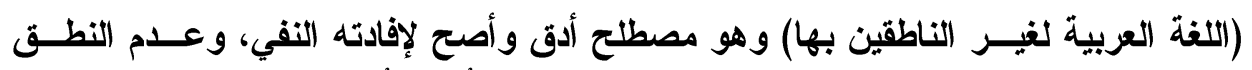

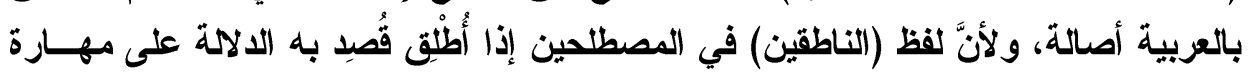

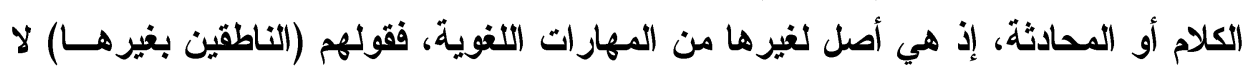

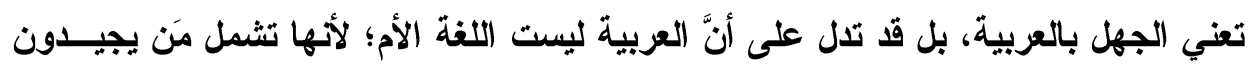

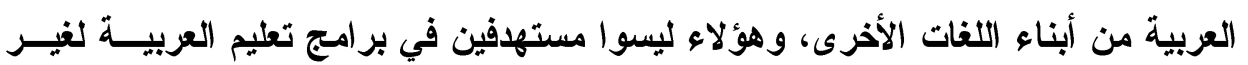

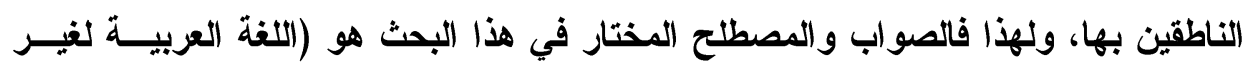

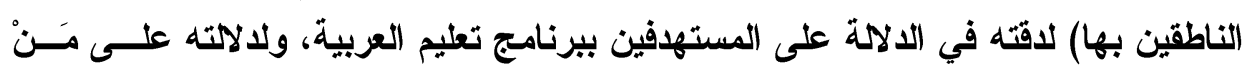

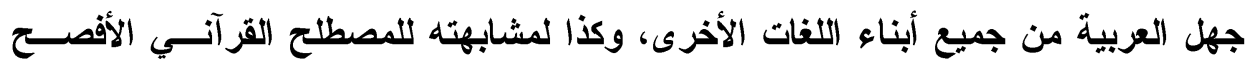

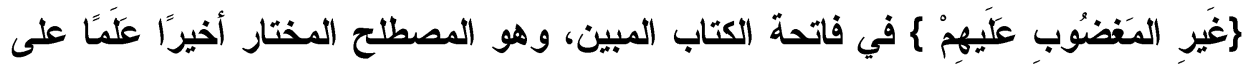

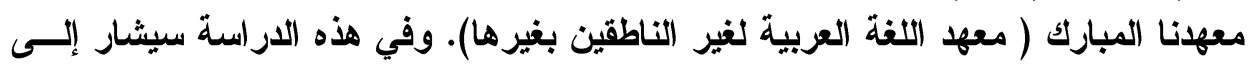
هذا الكتاب اختصارًا بـ (الكتاب الأساسي).

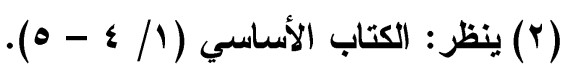


1 - منْسَجًَا مع العربية الفصحى الحديثة المستعملة في الأدب المعاصر ووسائل الإعلام.

r - مرتبطًا بالمو اقف الاجتماعية الحاضرة والعناصر التاريخيـة التـي يشتمل عليها الثراث.

r - كاثفًا عن القيم التبيلة والمبادئ الرفيعة التي تشتثل عليها الثقافــة العربية و الإسلامية.

ع - مختارًا للشائع من المفردات بحيث تُعدّ قائمة مكة التي تم إعــدادها قبل ذلك رفيقًا أمينًا له.

ه - مبرزًا للخصائص المميزة لتراكيب الجملة العربية وارتبــاط معنسى التركيب ثباتًا أو تغيرًا بهذه الخصائص... إلخ.

أما المؤلقون لهذا الكتاب الرائد فهم أعلام في علــم اللغــة العربيــة التطبيقي والنحو والصرف والتربية وتعليم العربية لغير الناطقين بها ، وهم:

د. عبد الله سليمان الجريوع • د. عبد الله عبد الكريم العبادي.

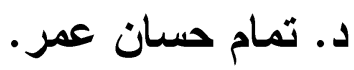
د. ـلي محمد الفقي.

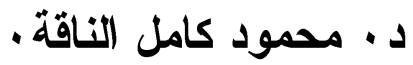
د · · رشدي أحمد طعيمة .

و أضيف إليهم في الجزء الرابع: د. عبد الواحد عبد الحافظ سليم، وفي 
الجزء السادس أضيف إليهه: د. محمد إبراهيم شـيبة، د. محمــد حسـين صبرة، د. السعيد عامر، د. المهاي إبراهيم عبد العال وآخـرون. فمعظـم هؤلاء أعلام على المستوى العربي ، وعطاؤهم منشور لا ينكره إلا جاحد. والكتاب الأساسي كتاب رائد في مجاله وفي وقته، لكنَّ التعليم تجارب متغايرة متطورة وما يصلح لتعليم جيل قد لا يصلح لأجيال متعاقبــة تتبــاين متطلباته التعليمية والبيئية المصاحبة له، والعلم رَحم بين أهله، ولا تكاد تجد رجلاً جمع العلم كله، وأحاط بجميع كلام العرب، فهذا وهمٌ ولا أصل له؛ لأنَّ

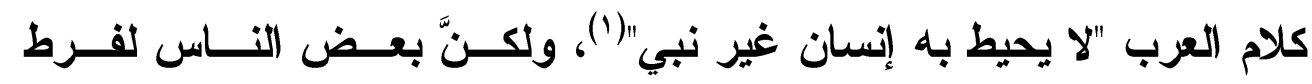
جمودهم على ما ألفوا يظنون أنَّ ما قاله بعض العلماء هو الحق الســاطع،

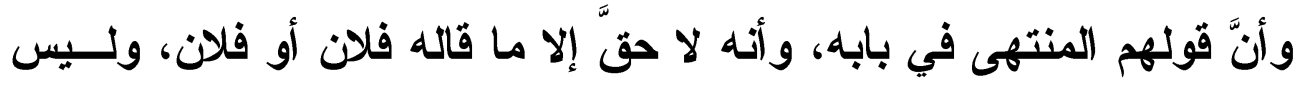
الأمر كذلك، فما من أحد إلا ويُقبل قوله ويُرد عليه إلا المعصوم - صلى الله عليه وسلم - نعم تلك حقيقة غائبة عن أذهان كثير من الباحثين مما يجعلهم يركنون إلى الكسل وحكاية أقوال العلماء السابقين وتكرارهـــا دون إعمــال الفكر والتدبر في أعمالهم، نعم لهؤلاء العلماء فضل السبق والريادة، ولنا أن نتدبر ما قالوا، وأن نتمِّم اللبنة الناقصة وفق رؤى لغوية وتربوية وتعليمية متطورة وخبرات تطبيقية في مبدان تعليم اللغة العربية لغير الناطقين بها. 


\section{ثانياً : هاهية النحو القُقَّم لغير الناطقين بالعربية ووظيفته:}

لم يتفق النُحاة قديمًا وحديثًا على ماهية النحو ووظيفته، ممــا أحسـث

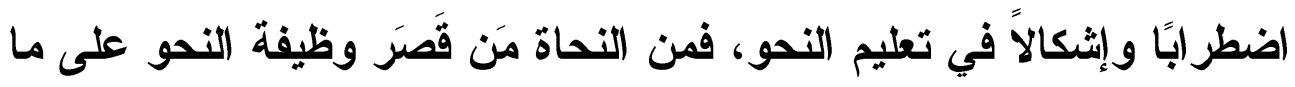

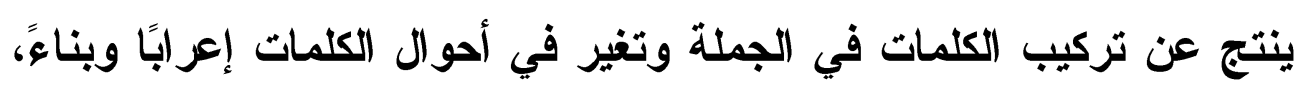

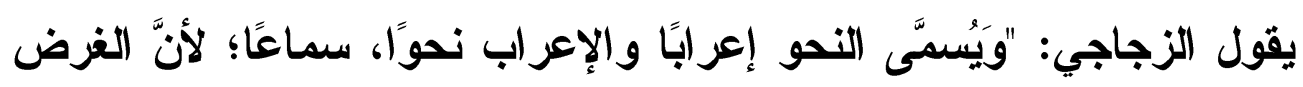

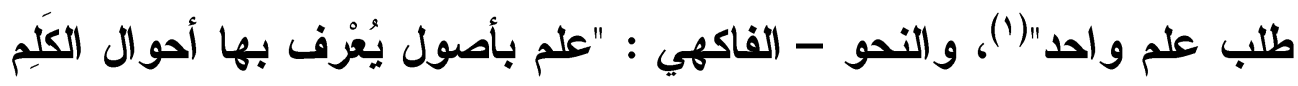

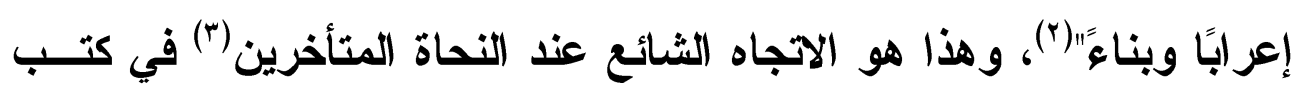

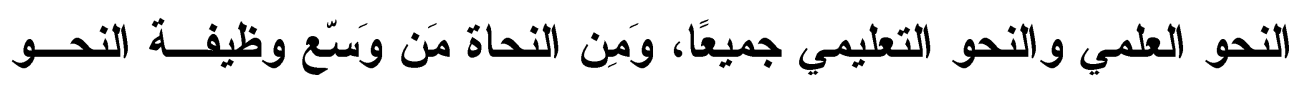

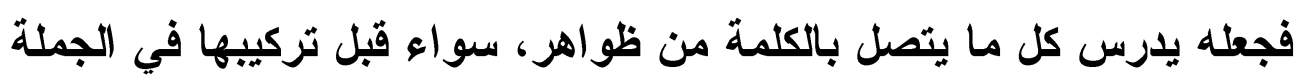

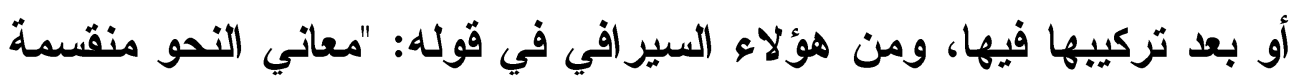
بين حركات اللفظ وسكناته، وبين وضع الحروف في مواضــعها المقتضـية هولية

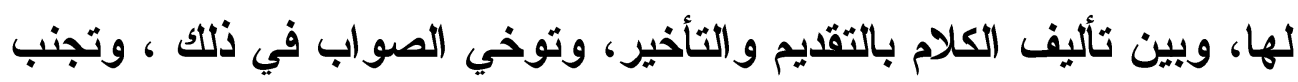

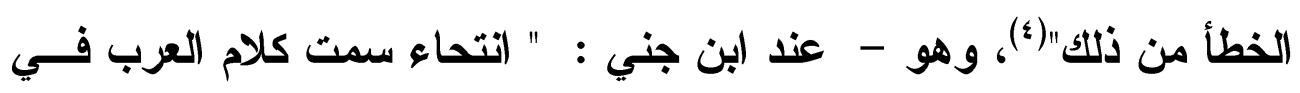

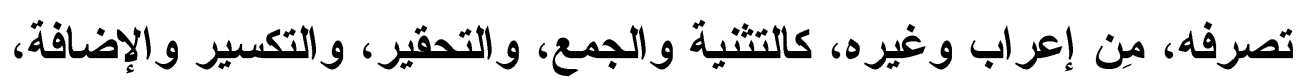

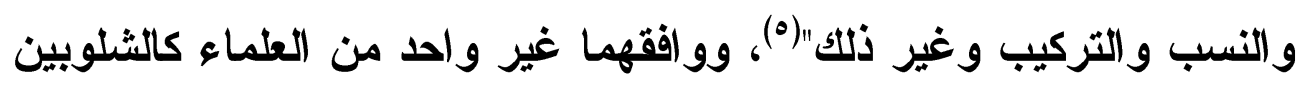

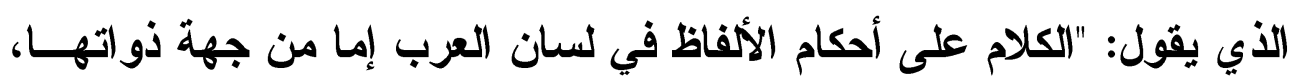

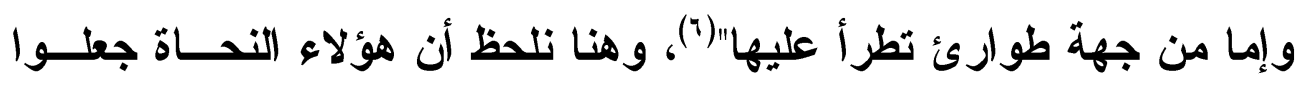

$$
\begin{aligned}
& \text { (1) الإيضاح في علل النحو (19). }
\end{aligned}
$$

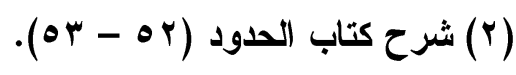

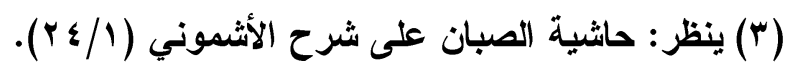

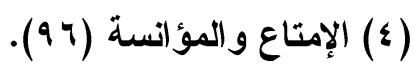

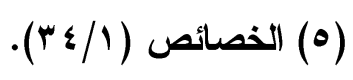

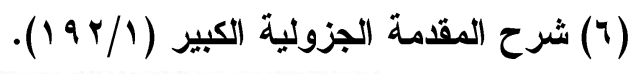


الصرف قِسمًا من النحو وليس قسيمًا له نحو ما صَرَّح به الرضي في شرحه

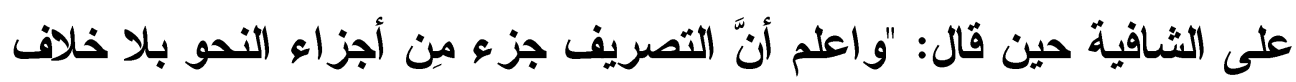

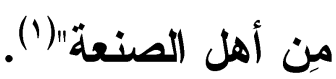

حقًا لم يكن النحاة الأو ائل يفصلون بين النحو وغيره من فنون العربية

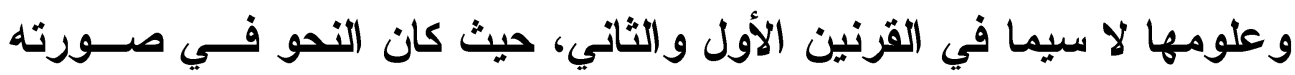

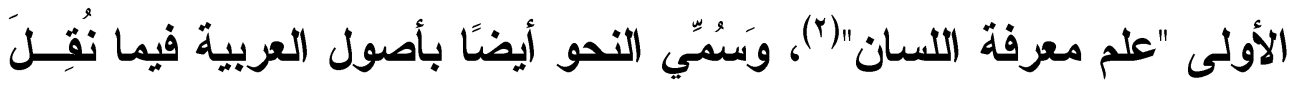

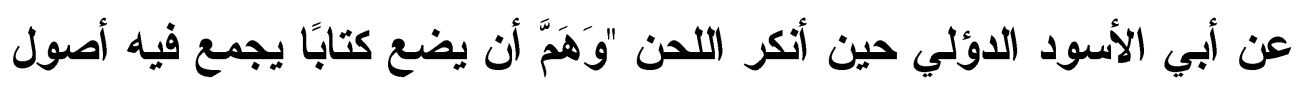
العربية"(")، لكنَّ أصل الإثكال والإلباس راجع إلى أفهام النحسـاة المتــأخرين وغيرهم حين خلطو ا بين وضع النحو و الغاية منه وطريقة تعليمه .

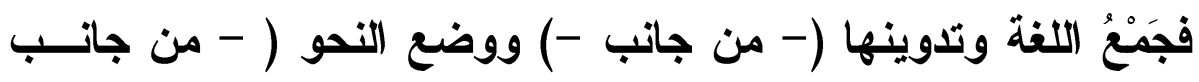

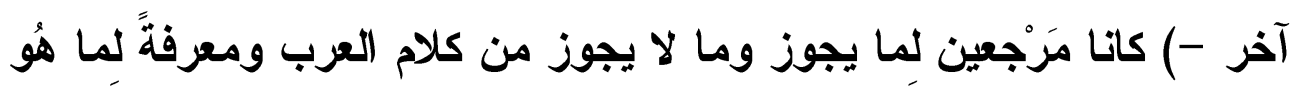

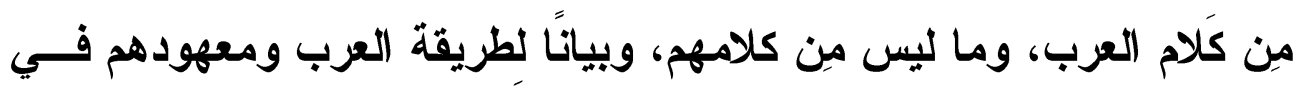

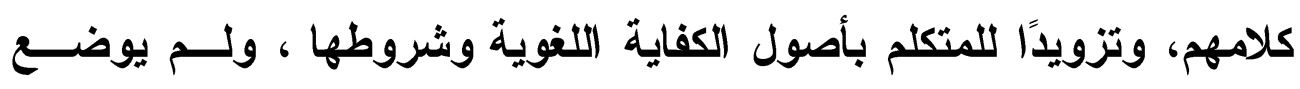

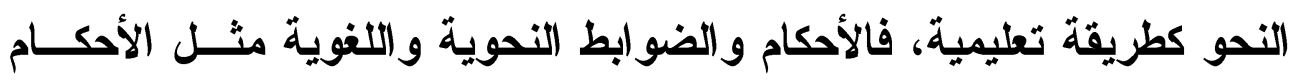
الفقهية تعتبر مرجعًا ودستورًا لمعرفة ما يجوز وما لا يجوز وليست طريقة ولئة

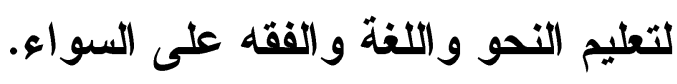

إنَّ الغرض الرئيس لوضع النحو أن يلحق غير المتقتين للعربية مسن

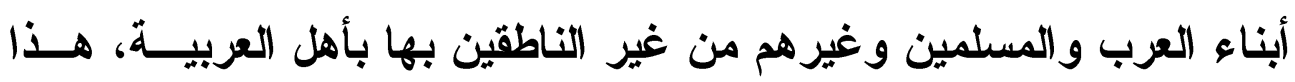

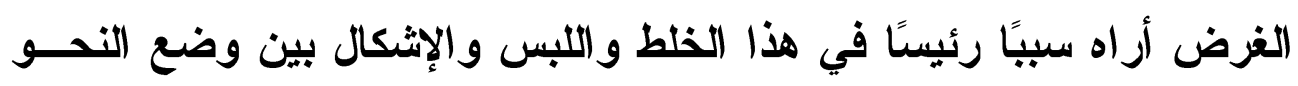

(1) (1) شرح الثافية للرضي (1/ ( ) ).

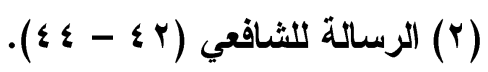

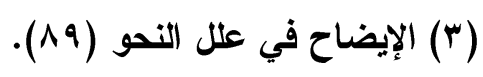


وطريقة تعليمه، وَمَردُّ هذا اللبس أقوال النحاة التي فُهمِت على غير مرادهم نحو قول ابن السر اج: "النحو إنما أُريد به أن ينحو المتكلم إذا تعلمــهـ كــلام العرب"(1)، ومثثله قول الزجاجي: "(لفائدة فيه - أي: النحو - الوصول إلــى التَّكَمْ بكلام العرب على الحقيقة صوابًا غير مُبَّلَّل ولا مُغَيَّ وتقويم كتاب الله

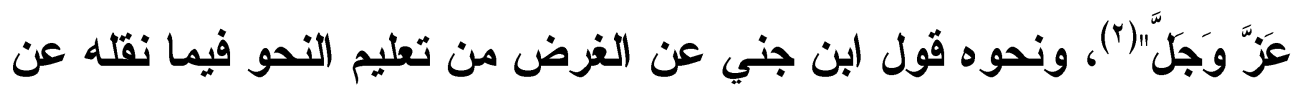

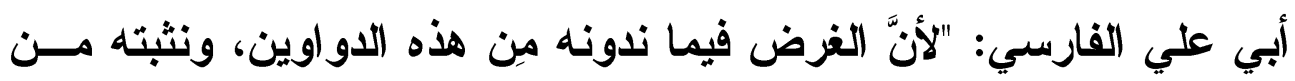

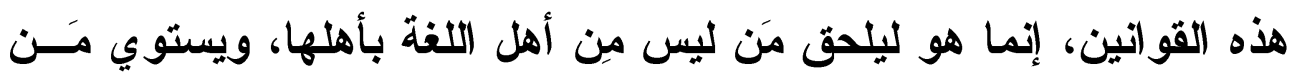

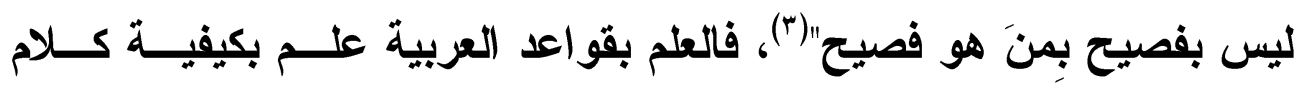
العرب وليس هو اللغة والكلام نفسه، يقول ابن خلاون في هذا الثــأن: "إنَّ العلم بقوانين الإعراب إنما هو علم بكيفية العمل وليس هو نفـس العمـلـ، وكذلك نجد كثيرًا من جهابذة النحاة والمهرة في صناعة العربية، المحيطـين علمًا بتثلك القواتين، إذا سُئل في كتابة سطرين إلى أخيه أو لـــي مـــودة أو شكوى ظلامة أو قصدٍ مِن قصوده أخطأ فيها عن الصواب وأكثر مِن اللحــن ولم يُجِد تأليف الكلام للألك، والعبارة عن المقصود علــى أســاليب اللســان العربي وكذا نجد كثيرًا ممن يُحسِن هذه الملكة (أي: اللغة) ويجيد القنين من المنظوم والمنثور، وهو لا يُحسِن إعراب الفاعل من المفعول، ولا المرفـوع

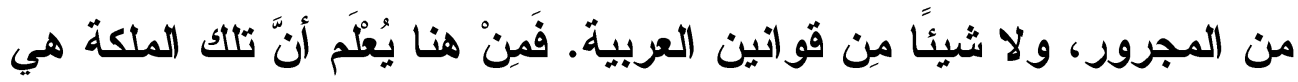
غير صناعة العربية، وأنها مستغنية عنها بالجملة"(؛).

$$
\begin{aligned}
& \text { (1) الأصول في النحو (1)/ (1) } \\
& \text { (r) الإيضاح في علل النحو (r) (r) (r). }
\end{aligned}
$$

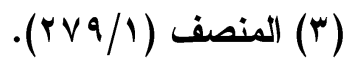

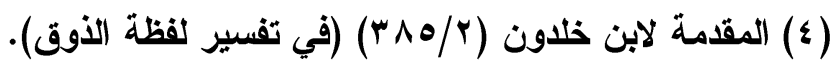


وهكذا فليس تعلم القواعد التحوية والصرفية هدفًا في حد ذاته، ولكنه

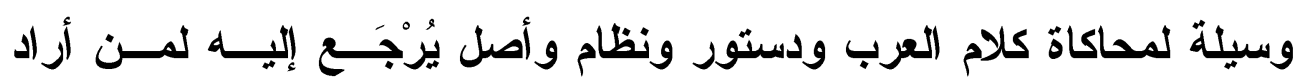
محاكاة سنن العرب في كلامهم.

ثالثا : النهو الملمي والنمو التمايسمي ومهاييز التزاكيبب النموية في تمليم العربية لغير الناطقين بها:

(النحو نحوان) حقيقة ثابتة قارة في أذهــان كثيـر مــن المختصـين بالعربية لكنها بلات غير واضحة تطبيقًا وممارسة في تآليفهم التعليمية قديمًا

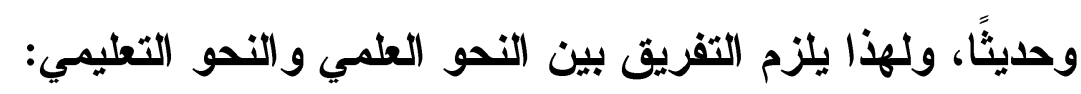
أما النحو الأول فالنحو العلمي: وهو يدرس النحــو لأتـــه، وغايتــهـ الإحاطة بالمعرفة النحوية كلها، والإدر الك الكامل لعناصر النظريــة النحويـــة

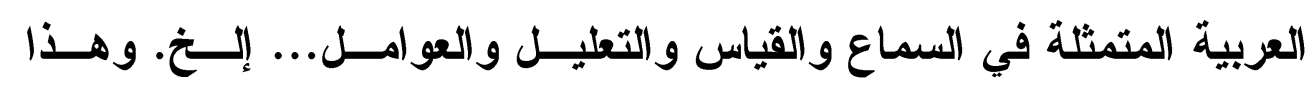
الإدراك لا يجب أن يكون كليًّا وشاملاً لكل جوانب النظرية النحوية والمعرفة ولية النحوية بكل تنوعاتها، وقا يستعين الباحث النحوي ببعض معطيات العلــوم الأخرى والار اسات اللغوية المقارنة رغبة في استيعاب كل تنوعات الظواهر

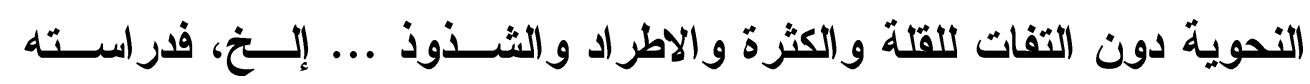

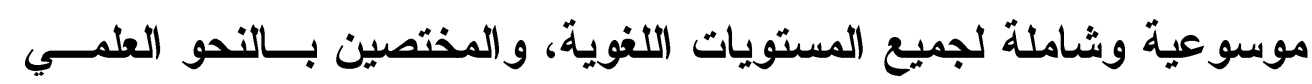
علماء المستقبل وحلقة الوصل بين تراثنا التليد وحاضرنا المجيد.

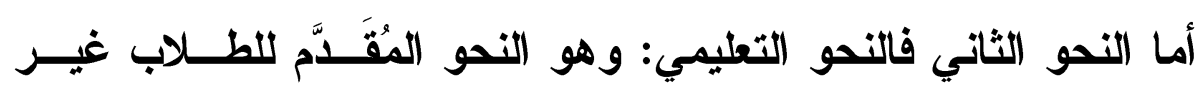
العارفين بالعربية من الناطقين بها وغير الناطقين بها، والنحو التعليمسي لا يتسم بالاستيعاب للظواهر كلها، وإنما هو مستوى معرفي يـهف إلى توظيف

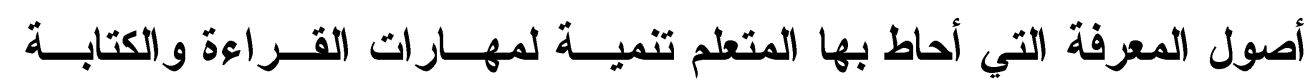


و المحادثة والاستماع، ولا تنحصر وظيفة النحو التعليمي في تلخيص الأبواب و المسائل النحوية في كتب النحو العلمي، بل يجب أن يكون بناءً كليًا كالنحو

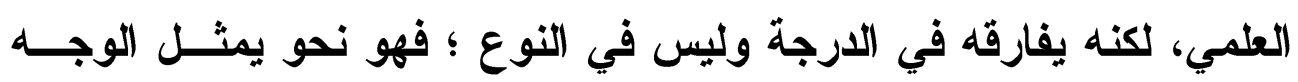

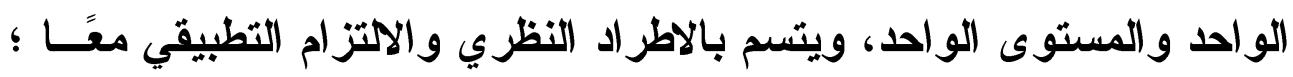

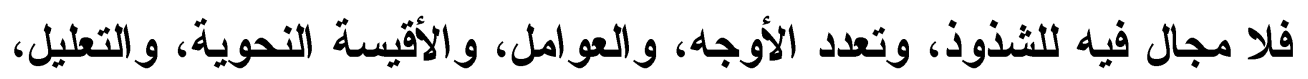

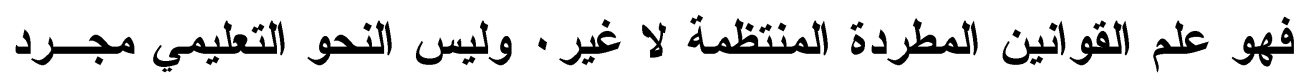

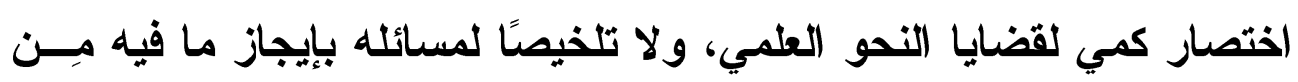

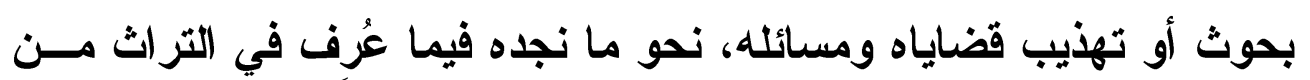

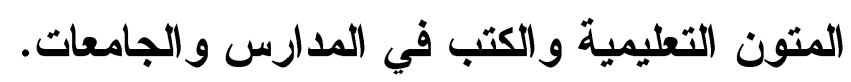

إن النحو التعليمي نحو استعمال وتواصل، وتلكت القواعــــ النحويــة لا

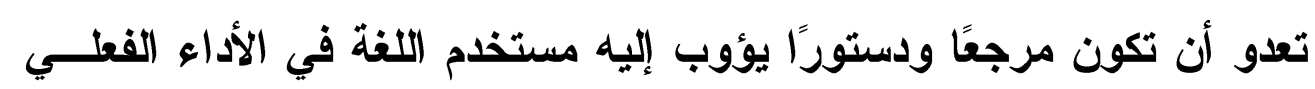

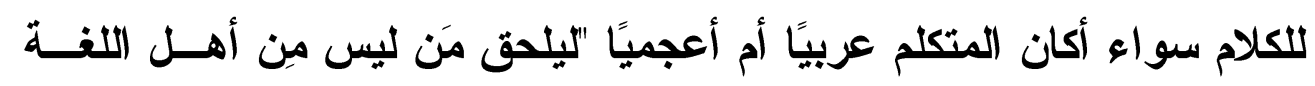

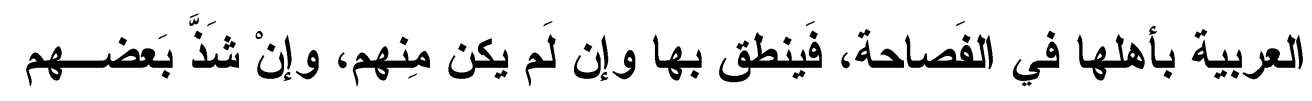

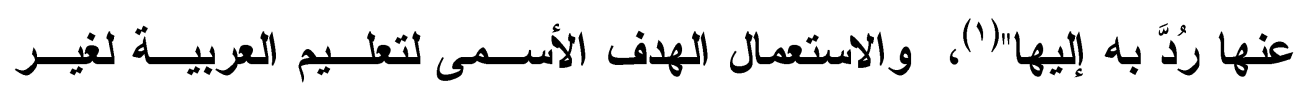

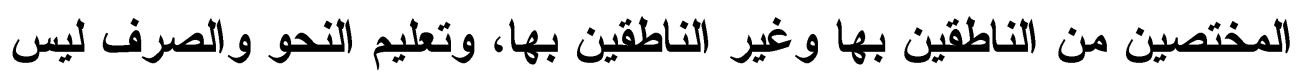

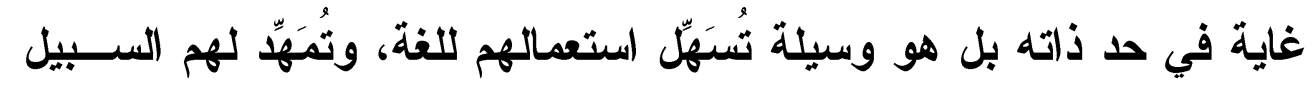

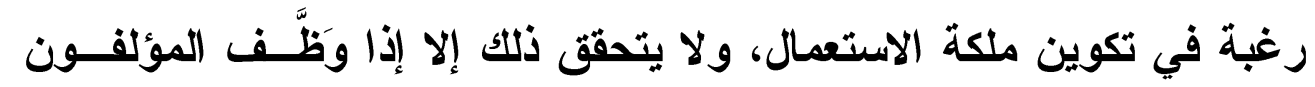

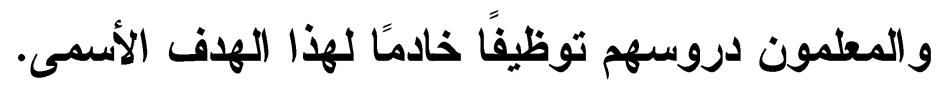

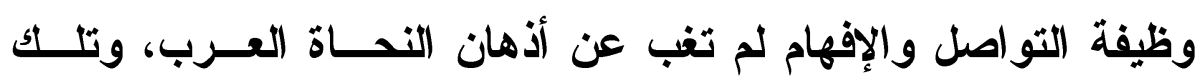

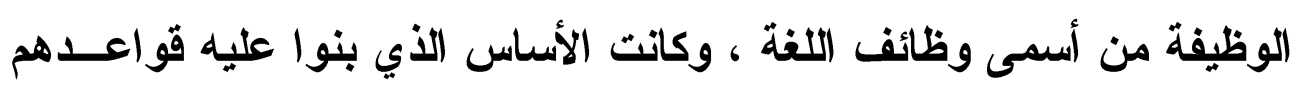

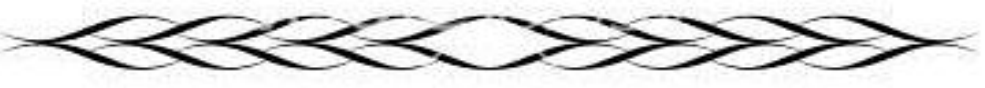


وتحليلاتهم ؛ فيجب على المؤسسات التعليمية إعادة تشكيل محتوى النحــو التعليمي المُقََّم للطلاب الناطقين بالعربية وغير الناطقين بها وفق المعساني الوظيفية للأبواب النحوية ؛ رغبة في تمكين الطلاب مِـن مهــارة الكتابــة الصحيحة والقول الفصيح، ويجب عَرض الأبواب النحوية وفق المعنى فـي إطار المركبات والأسباليب والجمل بعد مقدمة مــوجزة عـن أنــواع الكــلام وخصائص كل نوع وعلاماته من غير إهـــال للمــوروث النحــوي، ودون الالتزام بترتيب الأبواب وفق العامل، وألا يكون الإعراب الأساس في تصنيف المسائل والقضايا موضوع الار اسة؛ فموضوع (النداء) نموذجًا يجب إعــادة عرضه في إطار الأسـاليب النحوية، ولا يتم التركيز فيه على أنواع المنــادى وإعر ابه، بل يكفي معرفة الطلاب لأنماط النداء في العربية مع الإثارة إلـى الضبط الصحيح لها إجمالاً دون الخوض في تفاصيل إعراب وبناء المنادى، فالإعر اب فلسفة النحو وقمة التحليل، ومجاله النحو العلمي أصــالة، وفـي إطار المركبات يمكن عرض التوابع وغيرها تحث عنوان: المركب النعتـي، والمركب العطفي، والمركب البدلي، والمركب التمبيزي، والمركب العـددي، ويضاف إليها المركب الإضافي، والمركب الموصولي... إلـــخ ، والحــث أن ولن

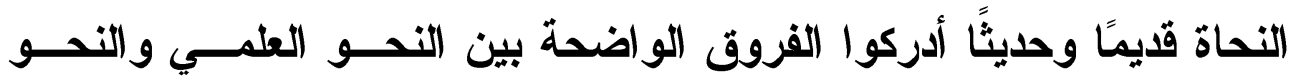
التعليمي، لكنَّ تلك الفروق لم تعدُ النظر والعقل غالبًا، وكثيرًا ما غابت عنهم في مؤلفاتهم التعليمية، وصارث متفاوتة وفق الرؤى الشخصية لأصــحابها، ولم تكن قوانين صارمة يُتحاكم إليها حينئذ.

وأما أبرز معايير التر اكيب النحوية وفق ما رصده المختصون ومنهم :

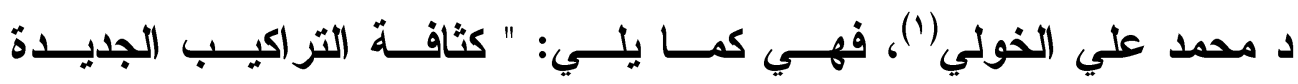
(1) تقييم الكتاب الأساسي لتعليم اللغة العربية لغير الناطقين بها ، ص اY ، ب r (بتصرف) . 
....ومناسبتها لعمر المتعلمين ، والسيطرة علــى المصــطلحات القواعديــة و...أولوية التر اكيب القياسية واستبعاد الثراكيب الثاذة، على أساس البداء بالأسهل ....وأولوية التراكيب الثائعة....وسياقية التر اكيـب ....أي: فـي سياق طبيعي عادي"، ويقول فيشر في هذا الصدد :" إن معالجة قواعد اللغة في إطار تعليم العربية كلغة ثانية تنطوي على عدد من المسائل الخاصــة . مسألة اختيار المنهج - مسألة الأسلوب - مسألة التــدرج.... ويجـب (1) التدرج من المهم والكثير الاستعمال إلى ما دونه في الأهمية والثيوع · (r)

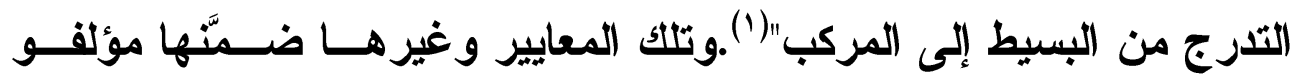
سلسلة ( العربية بين يديك) في مقدمة كتاب الطالب(1) ، إذ صدروا السلسلة

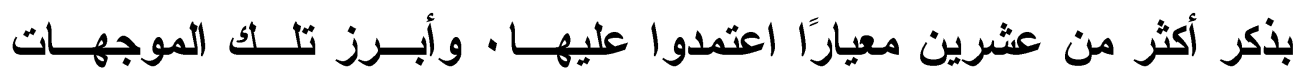

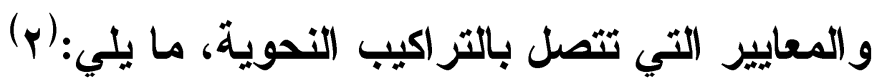
ا - مراعاة التدرج في عرض المادة .

r- الاهتمام بالجانب الوظيفي عند عرض تر اكيب اللغة وشرحها، وكذا

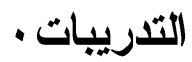

ب- استخدام تدريبات متعددة، ومتنوعة؛ فجاعت ذات طابع اتصــالي ، قائم على المشاركة والتفاعل . ع - ضبط التر اكيب في كل وحدة. ه- الإفادة من قوائم التزراكيب النحوية الشائعة .

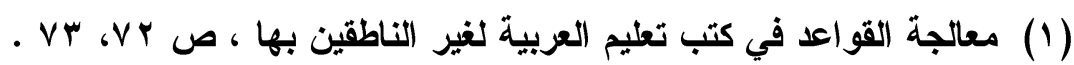

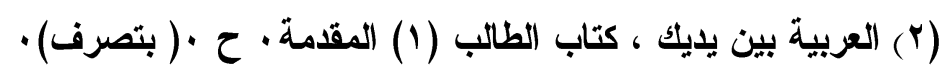




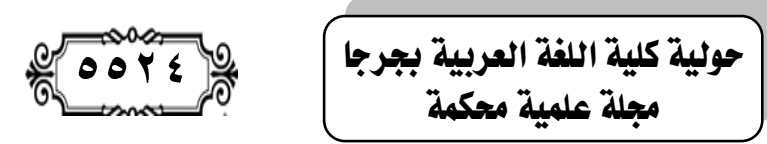

\section{رابعاً : الشاذ النحوي والصرفي تعليسياً:}

إنَّ ثنائَيَة الاطر اد و الثذوذذ هي ثنائية جَرَّدها الارس اللغــوي العربــي

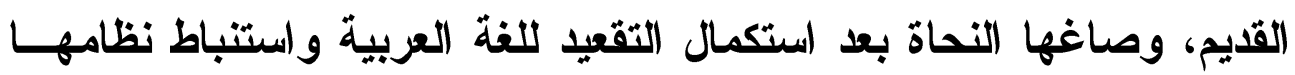

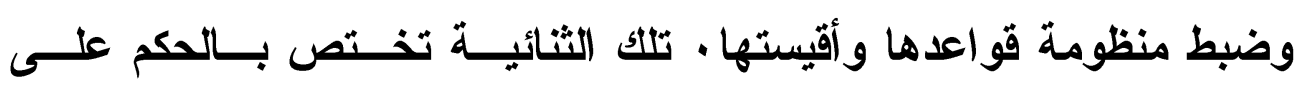

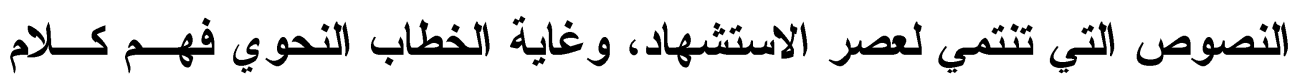

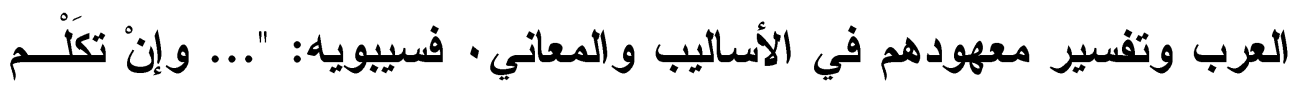

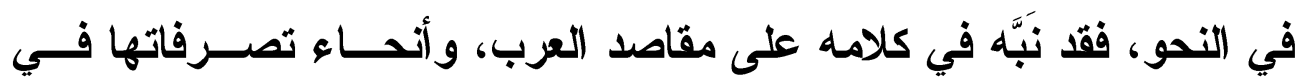
ألفاظها ومعانيها، ولم يقتصر فيه على بيان أن الفاعل مرفوع و المفعول به وله

$$
\text { منصوب، ونحو ذلك..." (1). }
$$

فوظيفة اللغة هي: تحقيق التواصل والفهر والإفهام، تلكك هي الوظيفـــة

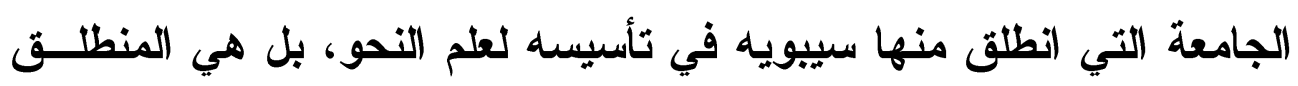

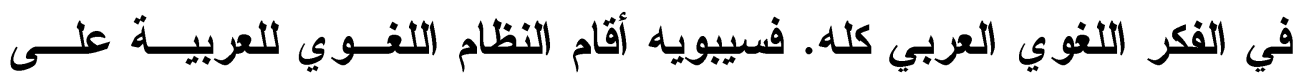

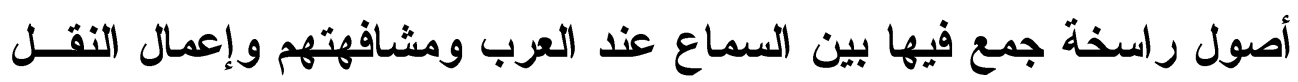

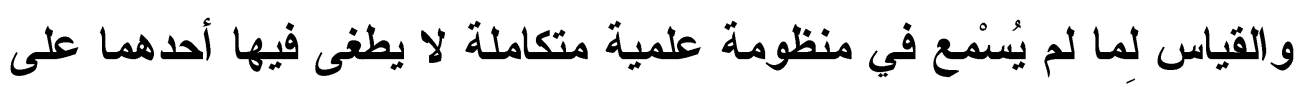
الآخر

فالثاذ في النظرية النحوية قسيم المطرد في الصحة أصالة، إلا أنه لم

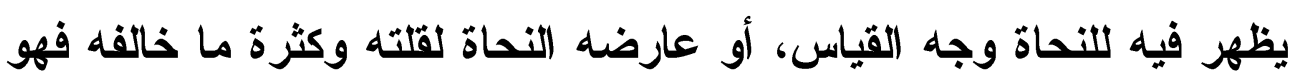

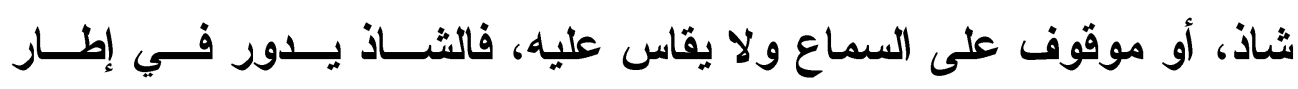

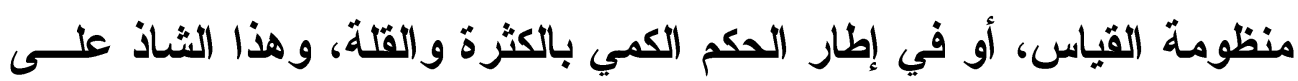



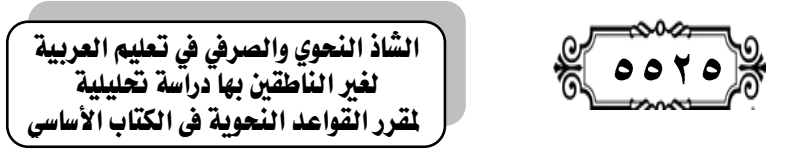

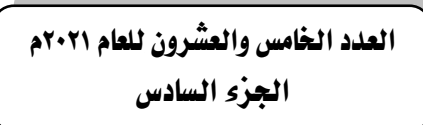

ثلاثة أقسام هي (1):

الأول: وهو (الشاذ في القياس المطــرد فـي الاســتعمال) كةـــهم:

(استحوذ) و(استنوق) إذ القياس قلب الواو فيهما - كما في نظائر البـاب -

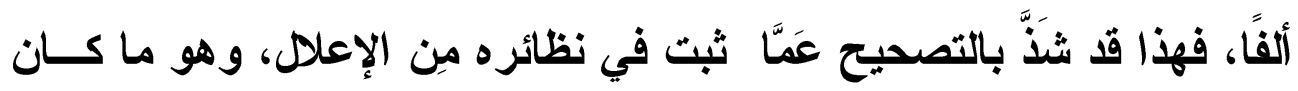
على (استفعل) معتل العين، نحو: (استقام) و(استطال) ونحوهما.

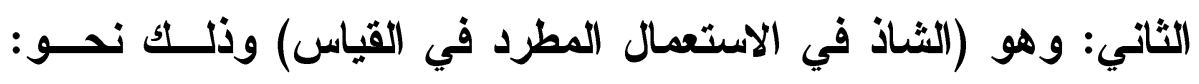

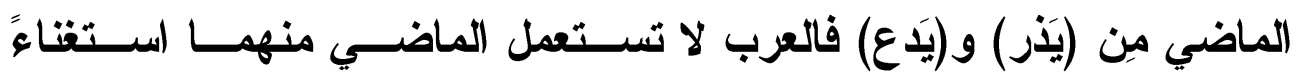
بغيرهما، مع أنَّ القياس يقبل ورود الماضي منهما (وذَرَ) و(وَََعَ) إذ الأصل

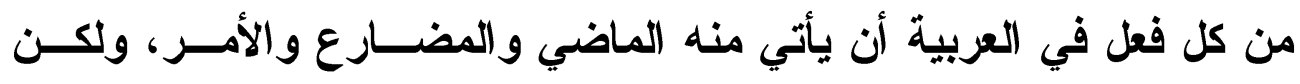
الماضي من هذين الفعلين مهمل غير مستعمل، وحينئذٍ لا نقول إلا ما قالتــهـ العرب.

الثالث: وهو (الثاذ في القياس والاستعمال معًا) ومنه: تصحيح عـين

مفعول ما عينه واو، نحو: (ثوب مصوون) و(فرس مقوود) فهذا شاذ عمـــا ثبت في القياس فيه نفسه، ومقتضى هذا الشذوذ التزام موضع السماع؛ لأنه خارج عن القياس في نفسه، وفي نظائره، فلا يقال: (عرْْض مصوون) قياسًا

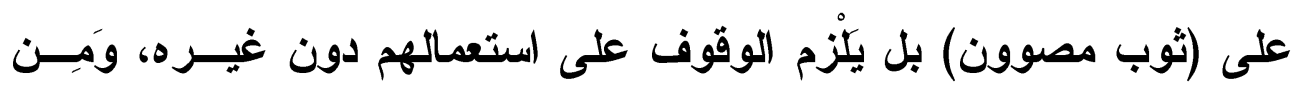

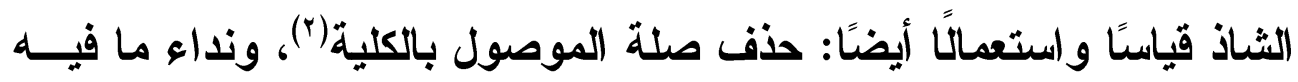

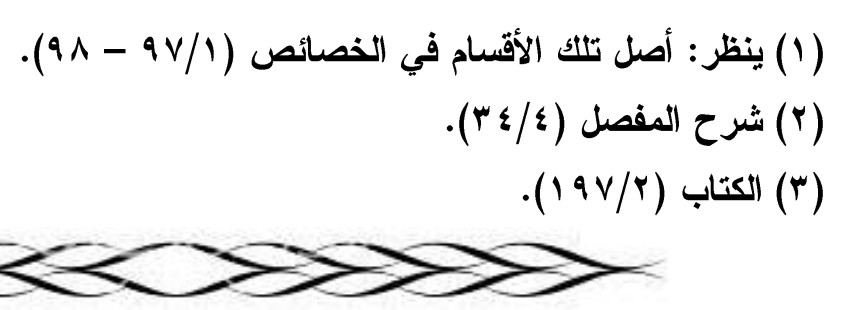


وحاصل القول أن مصطلح (الثذوذ) لا ينافي الفصاحة، فالثشاذ صحيح

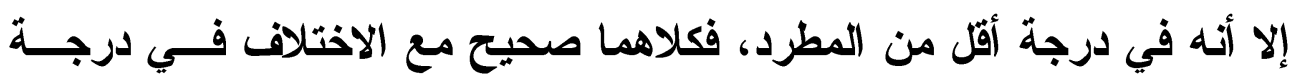

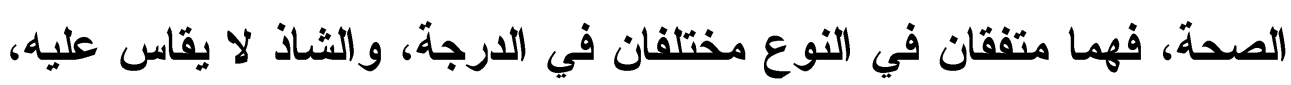

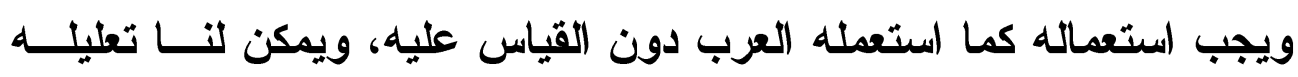

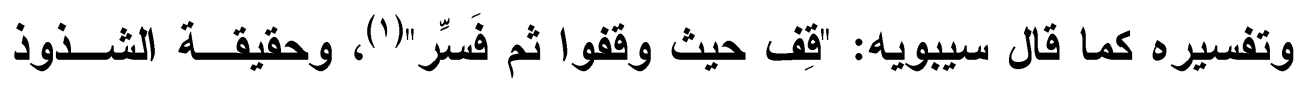
تنحصر في مخالفته للقواعد التي استظهرها النحاة بعد استقصائهم لأوضاع

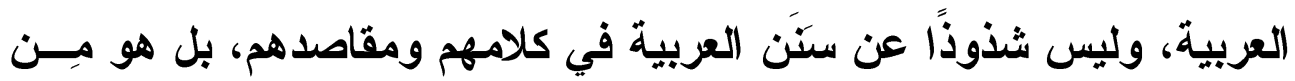

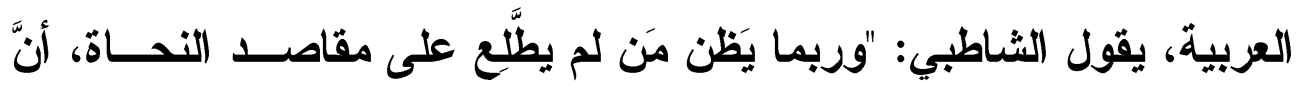

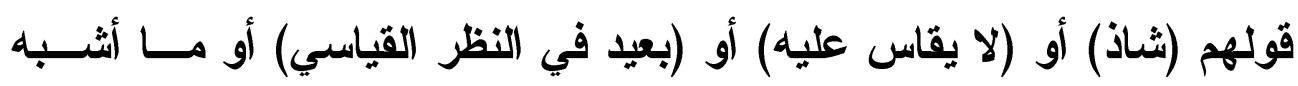

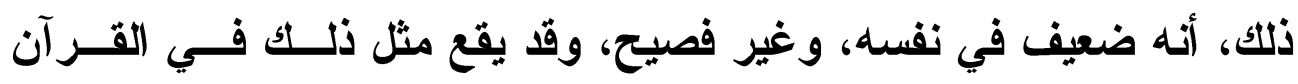

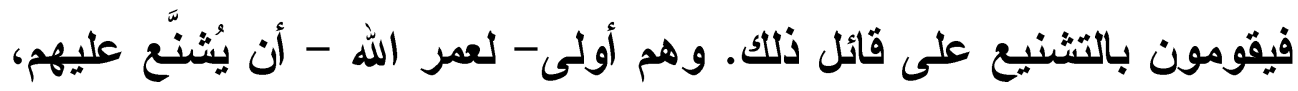

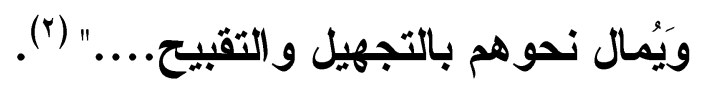

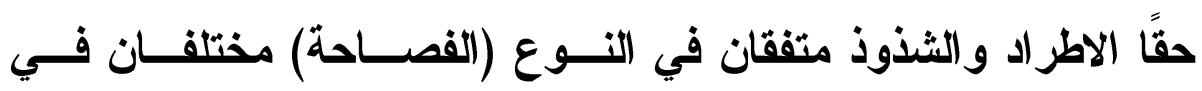

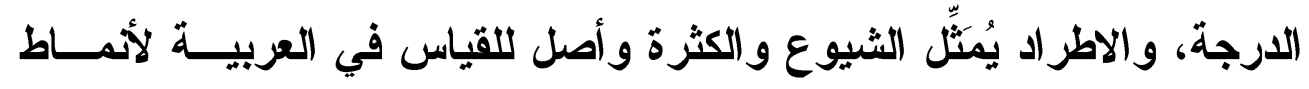

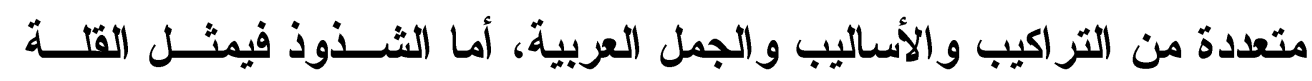

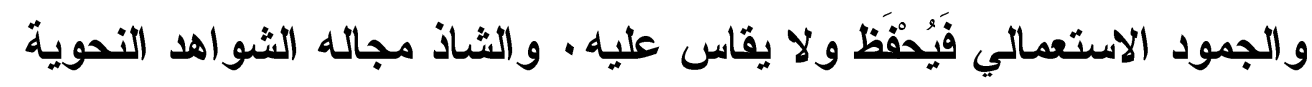

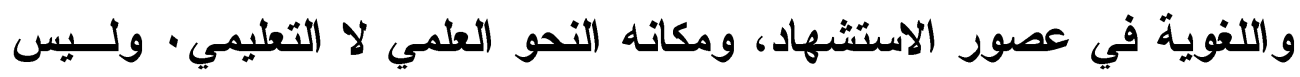

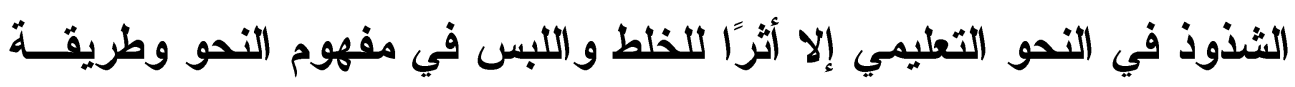

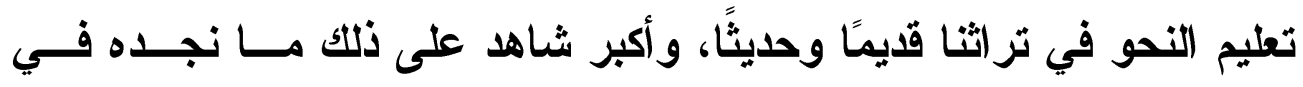
المتون التعليمية قديمًا و الكتب المدرسية و الجامعية حديثًا.

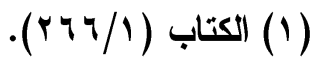

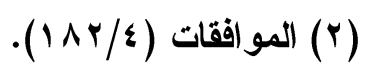


و هذا الثذوذ في النحو التعليمي مجاتب ومجافٍ لطبيعة التعليم القائمة

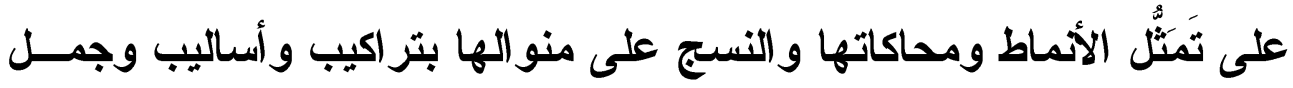

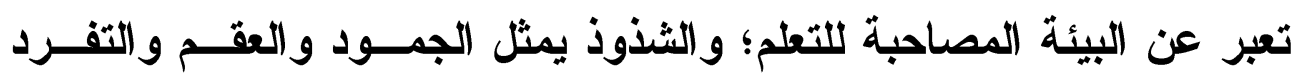

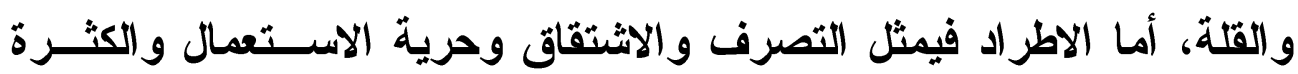

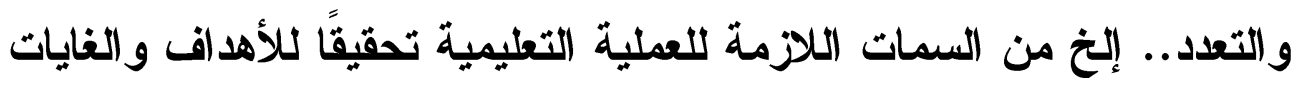

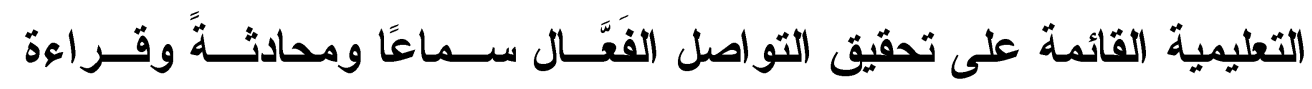
وكتابة.

و النحو ليس مشكلة ومعضلة في ذاته، ولكنَّ الإثكال و اللبس يأتيــان

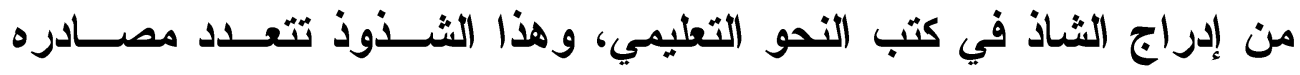

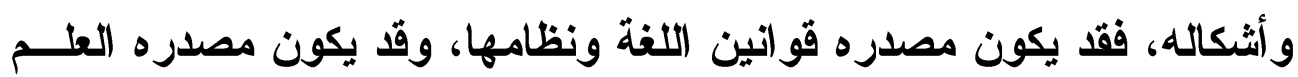

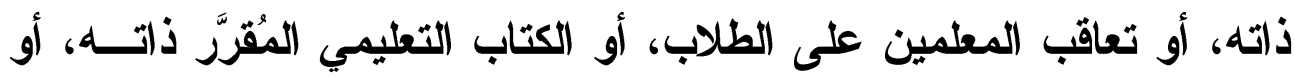

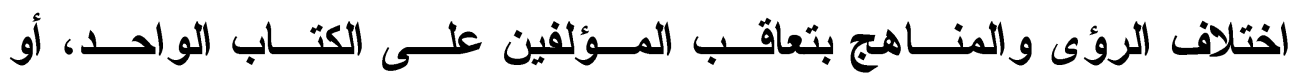
الاختبار ات، والتدريبات ... إلخ. وقد آثرت دراسة الثثاذ النحوي و الصرفي في كتــاب نتليـــي لغيـر

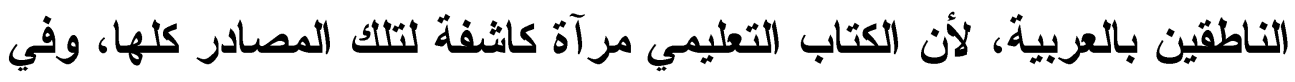

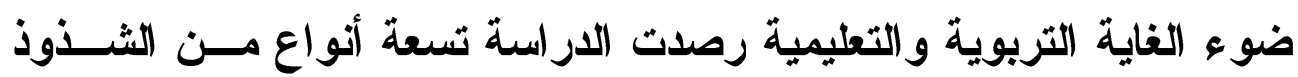

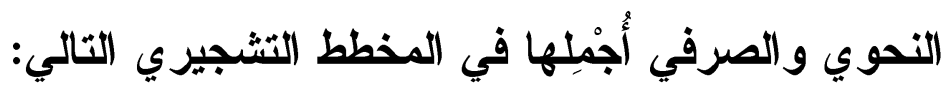




\section{الترقيير الدولي 2356-9050 25SN ISSN 2636 - 316X X

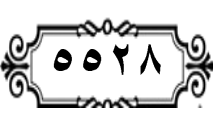

\section{هُطط الشاذ النحوي والصرفي في الكتاب الأساسي}

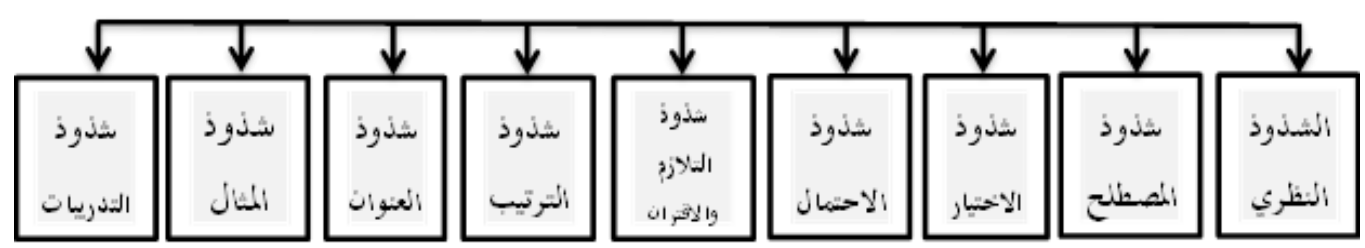

وتفصيل تلك الأنواع والأثنكال كما يلي:

\section{| - الشذوذ النظري (الصناعي):}

حرص المؤلفون للكتاب الأساسي على أن تكون مفردات مقرر القواعد

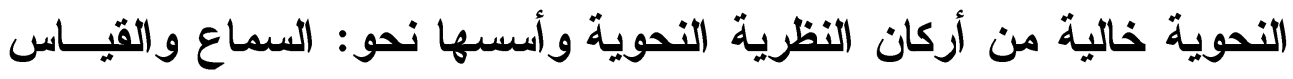
و العامل والعلل وخلافات النحاة... إلخ رغبة في أن يكون النحو المعَقَّمَ لغير

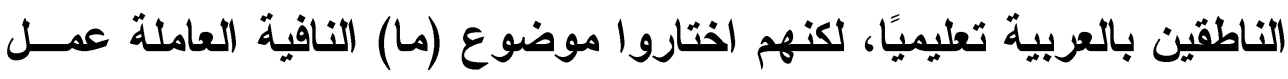

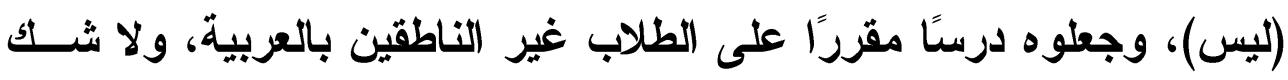
أن اختيارهم هذا الموضوع شاذ في أصول النظرية النحوية لوجهين:

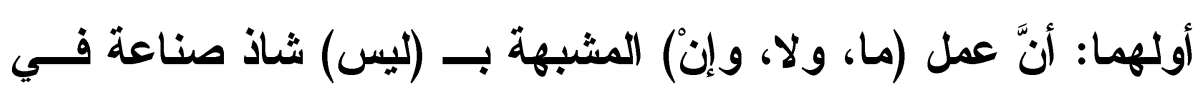

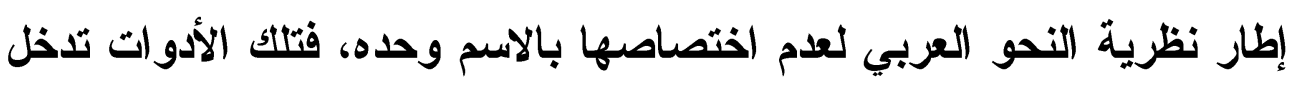

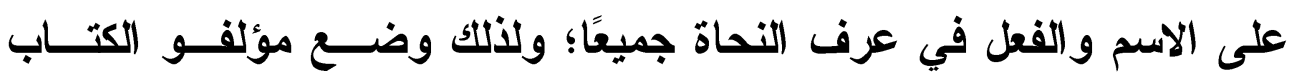

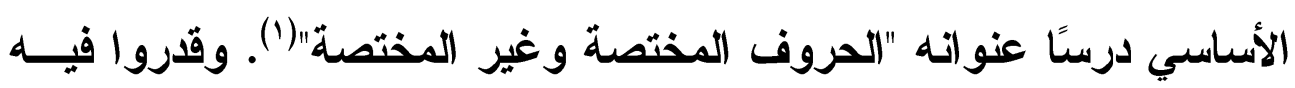

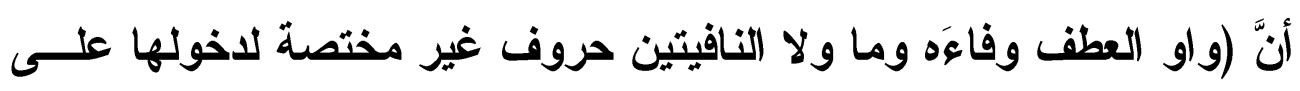

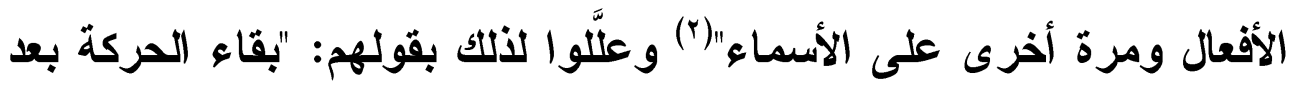

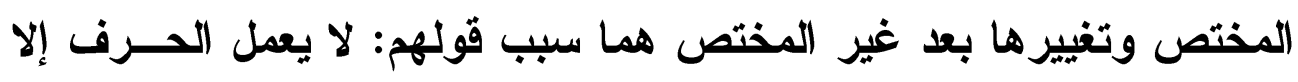

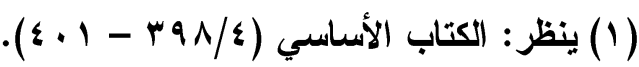

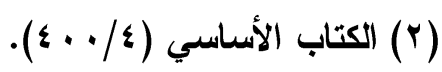




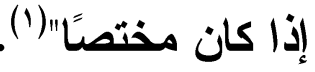

والوجه الثاني لشذوذ (ما): قلة استعمالها وعدم استخد(مها في غيـر النص القرآني فــ(ما) الحجازية العاملة عمل (ليس) في كتب النحــاة فـي مقابل (ما) التميمية المهملة، أثنار إلى ذلك أبو حيان في سياق حديثه عـن (لا) النافية نظيرة (ما) النافية العاملة عمل ليس ومخبرًا أنَّ عملها "في غاية

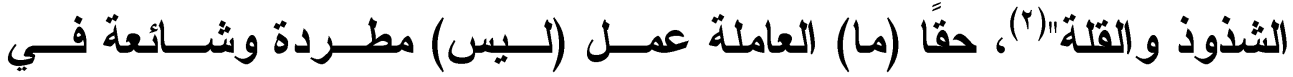
الاستعمال القرآني إلا أنّ هذا الاستعمال استعمال مخصوص، ولكنــه شــاذ وقليل الاستعمال في غير النص القرآني، فهنا شذوذان: شــذوذ فـي أصـلـ النظرية النحوية؛ لأنَّ (ما) أداة غير مختصة بالاسم وحده، فلا تعمل أصــالة في النظرية النحوية، وشذوذ آخر في الاستخدام اللغوي خلا النص القرآني،

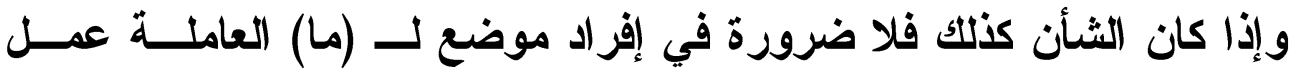
(ليس) في نحو تعليمي مُقََّّم لطلاب غير ناطقين بالعربية؛؛ لأنَّ (ما) الحجازية العاملة عمل (ليس) الأصل عدم إعمالها لعدم اختصاصها ولكثرة اســتعمالها مهملة، وإنما إعمال (ما) في العربية جاء على غير قياس مخالقًا للأصل في إهمالها وعدم إعمالها، ومما زاد الشذذوذ شذوذًا آخر سرد شروط عمل (ما) الحجازية()، ومنها قولهم: "أن لا يتقدم خبرها على اسمها ما لم يكن الخبر شبه جملة، فإذا تقدم الخبر، ولم يكن شبه جملة بطل عملها مثل: ما كـريم

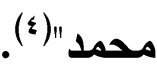

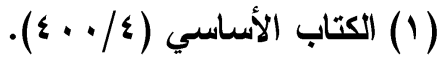

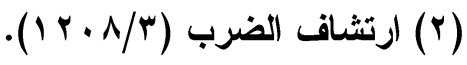

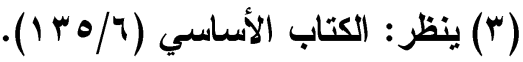

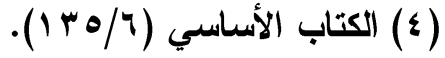


وَمِن مظاهر الثذأوذ في النظر النحوي لمؤلفي الكتاب الأساسي ذِكرهم

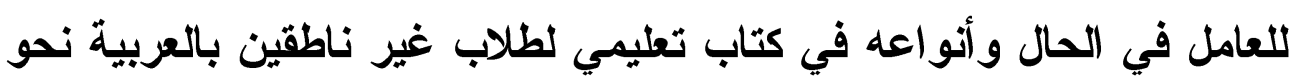

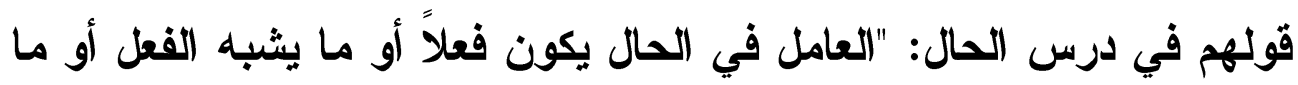

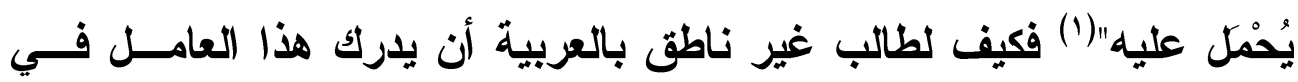

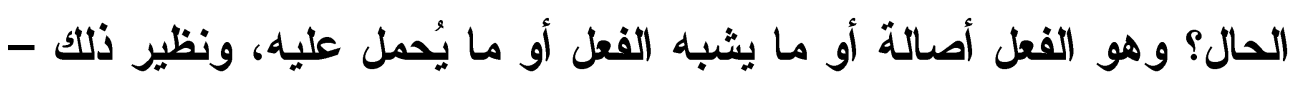

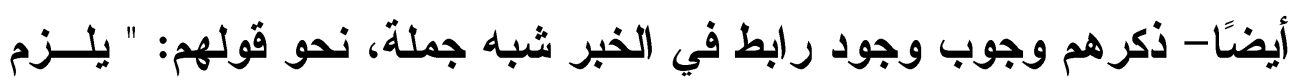

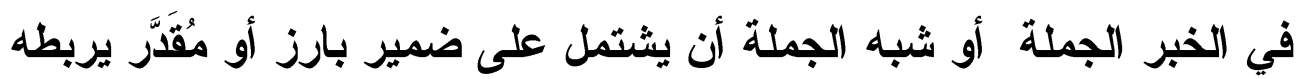

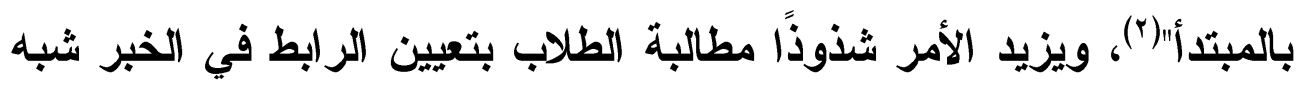

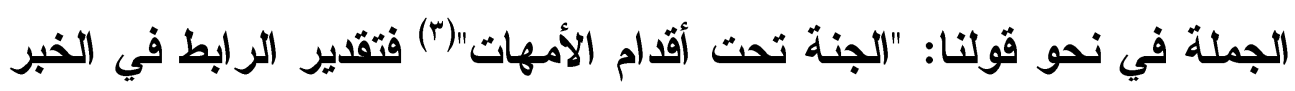
شبه الجملة يمثل غاية الثذوذ في كتاب نحو تعليمي لطلاب غيــر نـاطقين

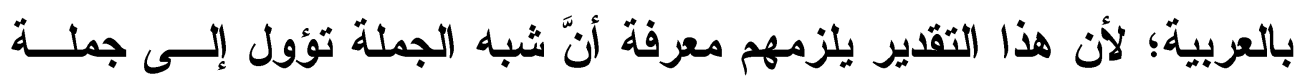

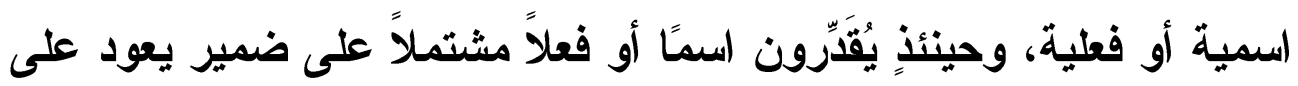

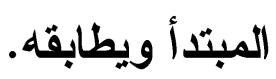

ومن ذلك أيضًا عرضهم لخلاف النحاة في جمود (لــيس) و(دام) فـي

قولهم: "هذه الأفعال منها ما لا يتصرف مطلقًا وهو (ليس) باتفــاق، و و(دام)

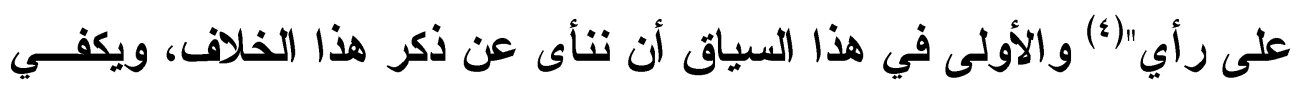
القول أنَّ (ليس) و(دام) جامدان.

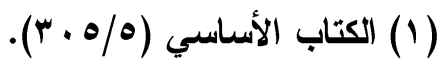

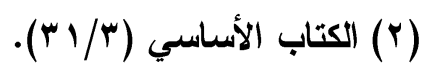

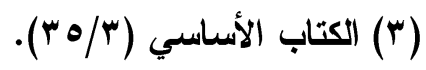

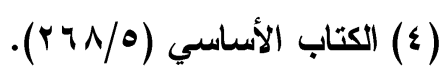



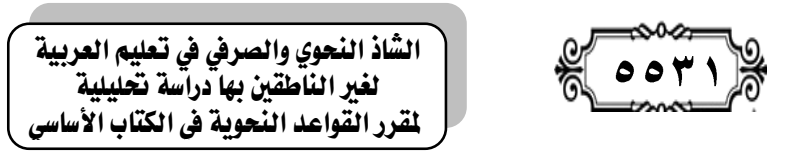

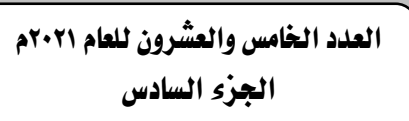

ومن مظاهر الثذوذ النظري أيضًا حرص المؤلفين على تعليل النســـخ

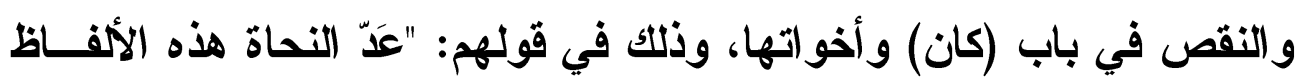

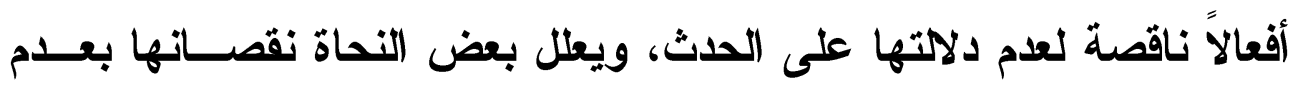

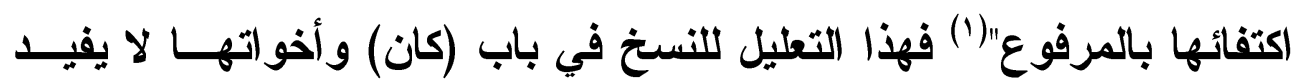

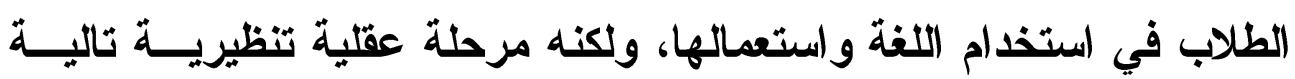

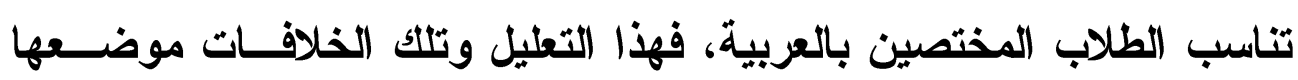
النحو العلمي لا النحو التعليمي. وكذلك مِن مظاهر الثذوذ النظري في الكتاب الأساسي ما رصدته من

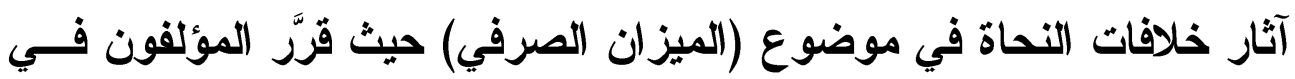

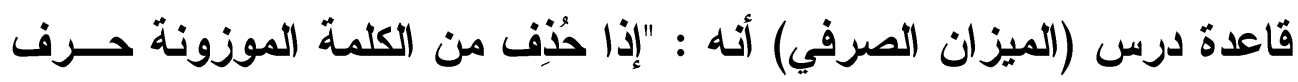

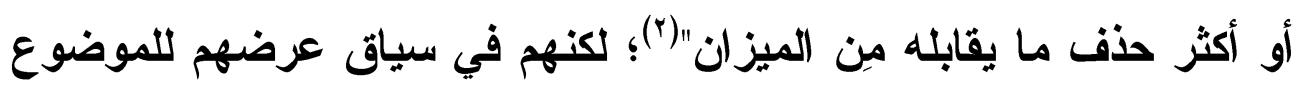

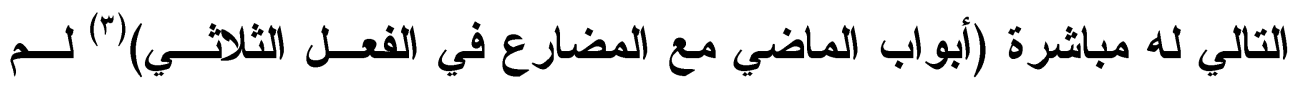

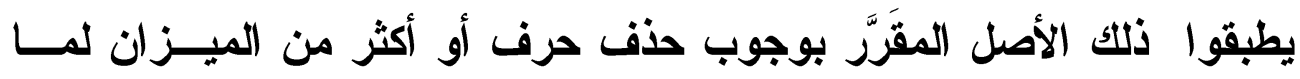

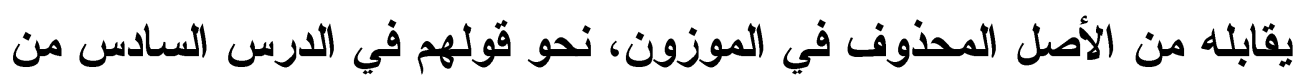

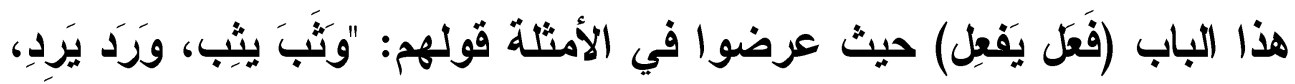

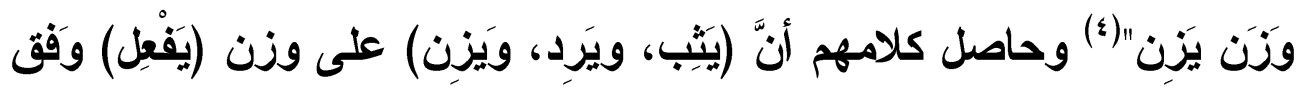

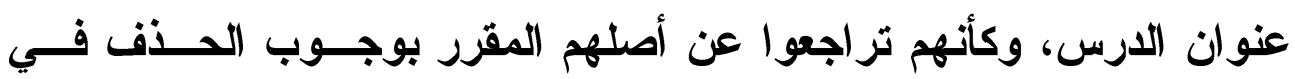

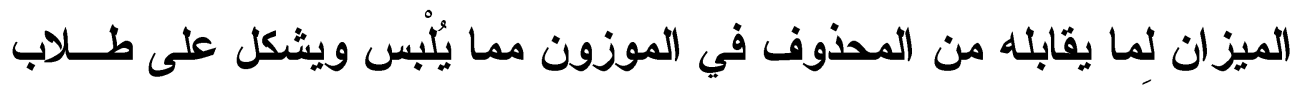

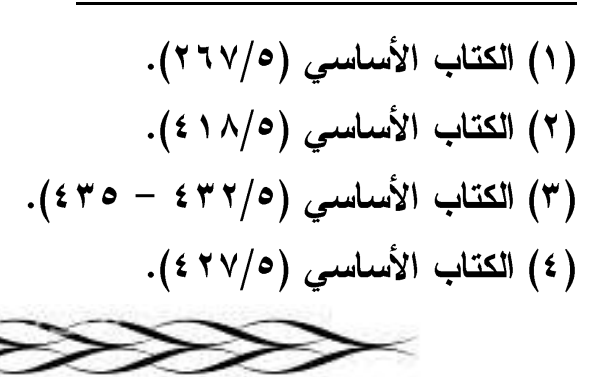


العربية من الناطقين بها وغير الناطقين بها • إذ يتساعلون: لماذا المــوزون

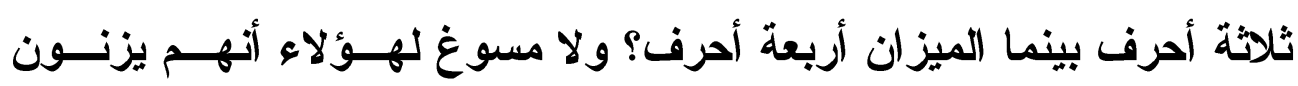

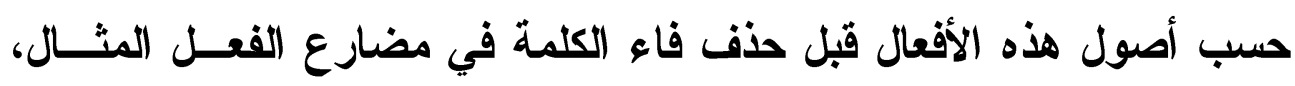

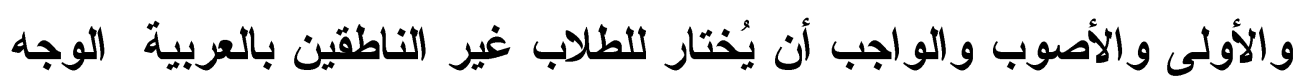
المناسب، وهو قول القائل : بمقابلة المحذوف من الموزون بحذف ماند ما يماثله

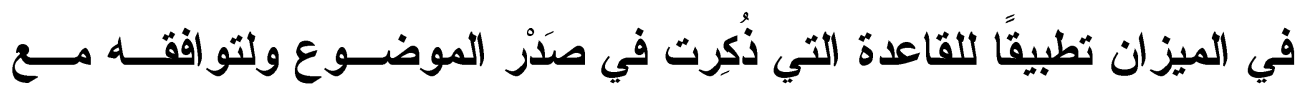
المنطق والظاهر المُعَاين لاى الطلاب.

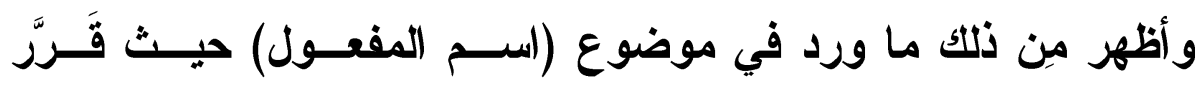

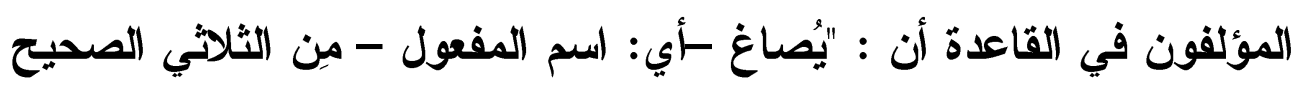

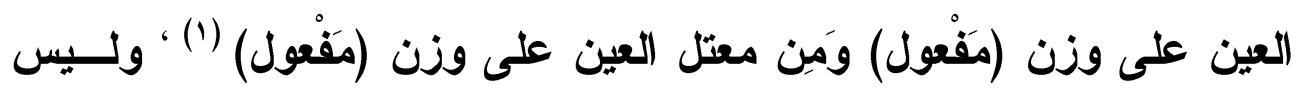

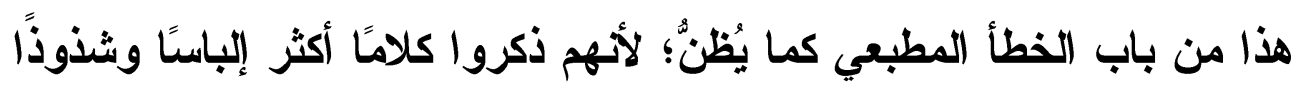

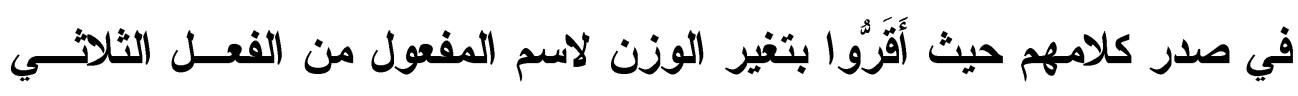

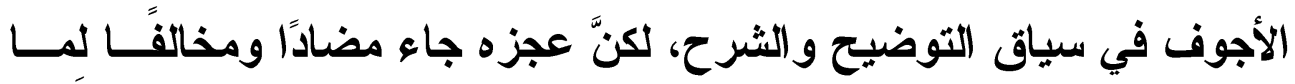

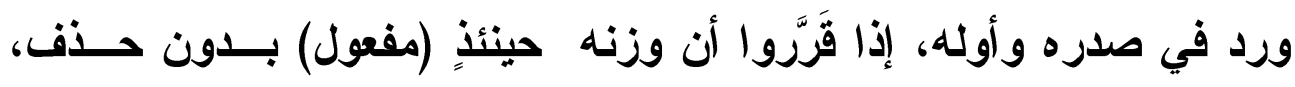

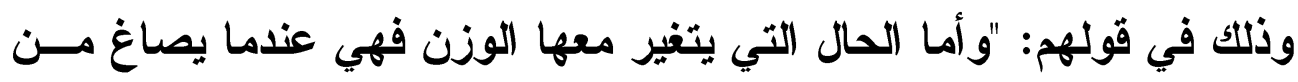

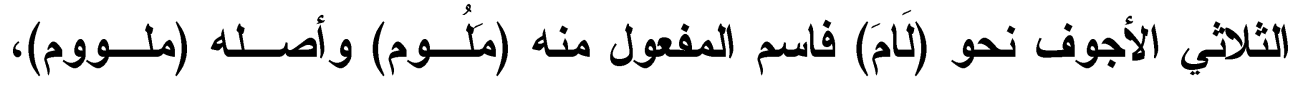

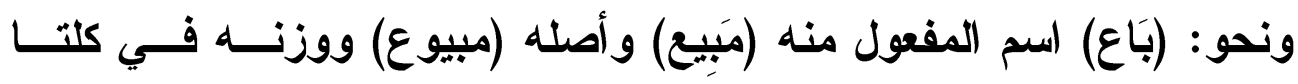

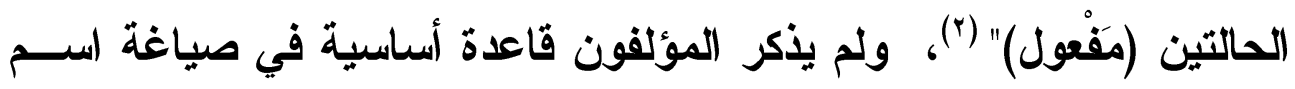
المفعول، وهي: صوغه من الفعل المبني للمجهول وليس من الفعل المبنـي

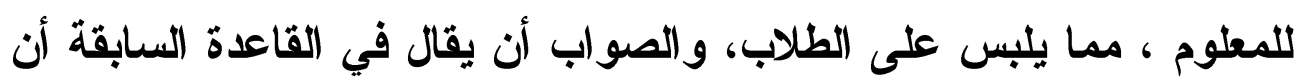


اسم المفعول محل البحث ( ملوم) يصاغ من الفعل المبني للمجهول (ـــيم)

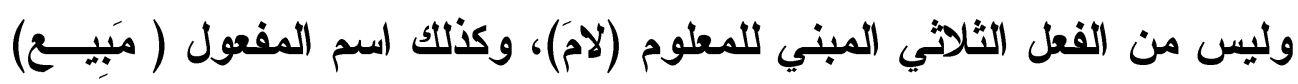

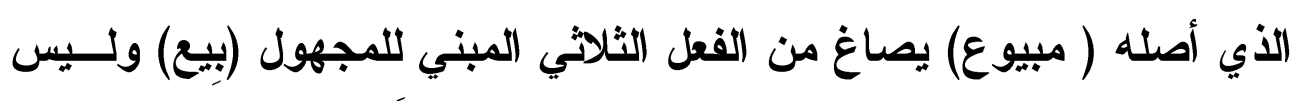
من الفعل الثلاثي المبني للمعلوم ( باع) كما ذكروا آنفاً. واختار البعض القول بأن الاثتقاق في العربية يكون من الجذر اللغوي

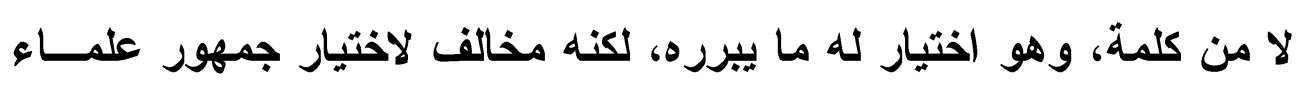

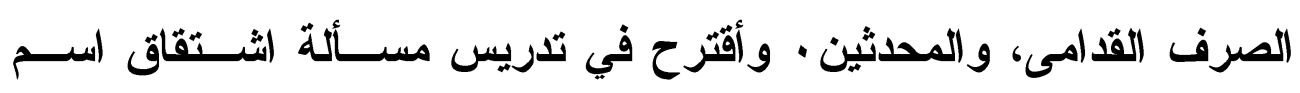
المفعول من الفعل الثلاثي الأجوف للطلاب غير الناطقين بالعربية، خروجِّا

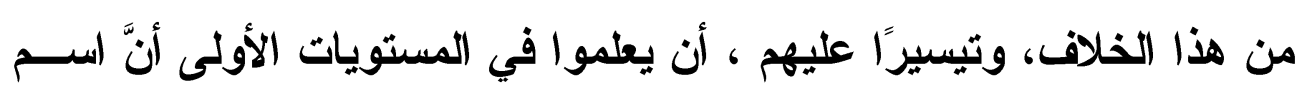

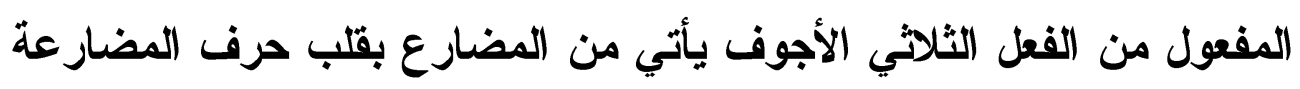

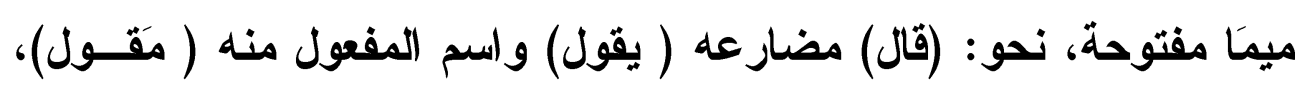

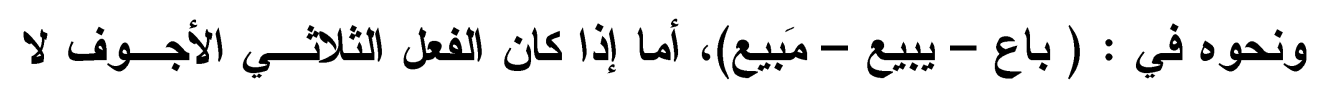

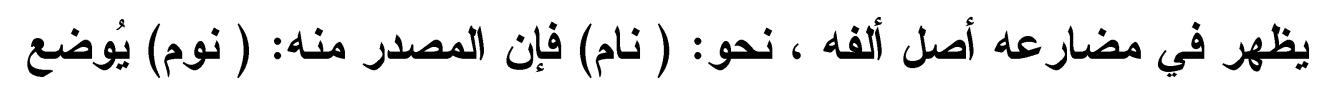

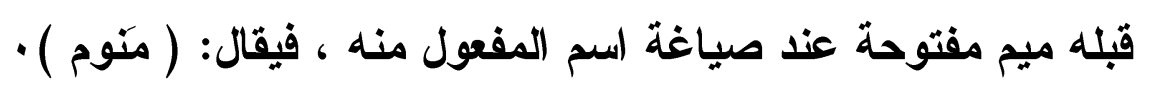
وهذا - لعمري - عين الثذوذ الواجب إخلاء كتب النحو التعليمي منه

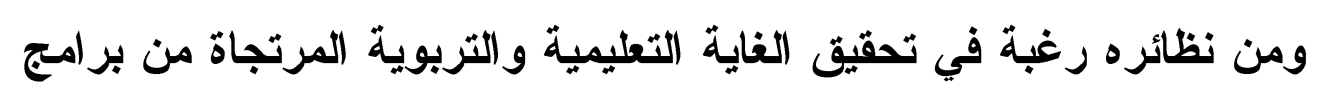
تعليم العربية لغير الناطقين بها.

هذا التخالف والتضاد والثذوذ أثر ونتيجة لخلاف النحاة الأوائل فـي

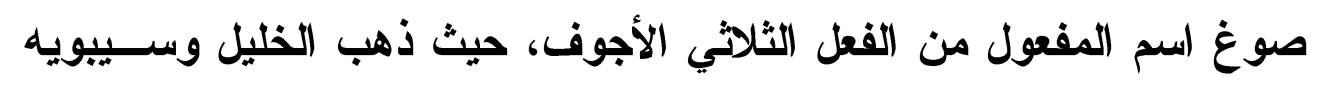

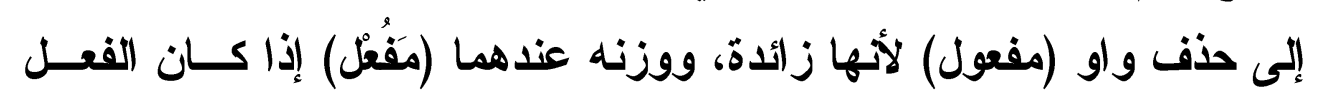

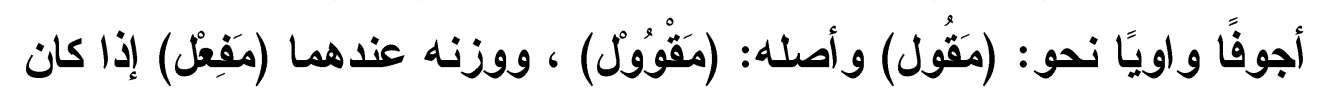

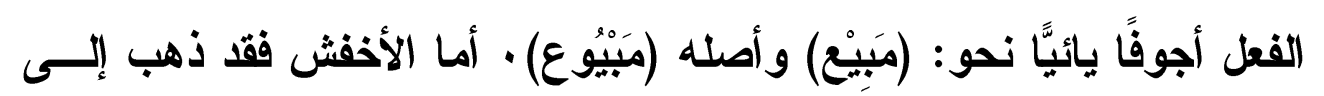


حذف الواو الأصل، وهي عين الفعل، ووزنه عنده (مفُول) • فمذهب هــؤلاء

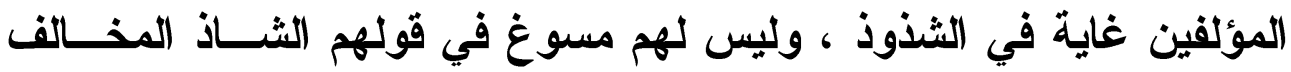
للر أيين المشهورين في هذه المسألة، وليس لهم اختيار رأي الخليل وسيبويه

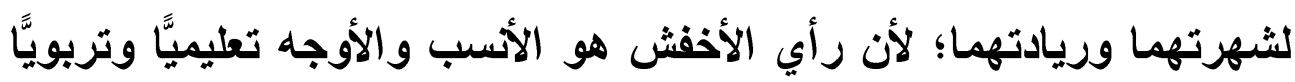

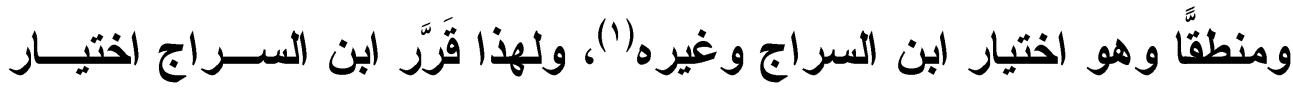

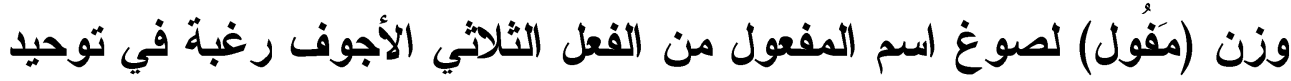

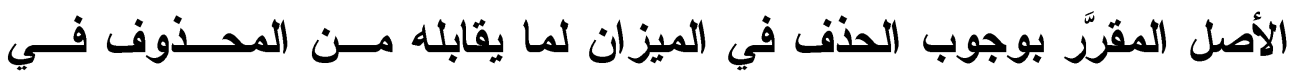

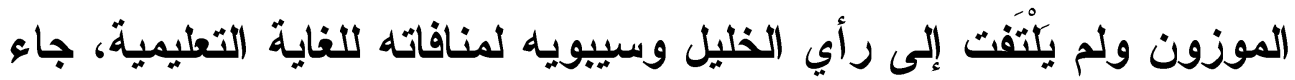

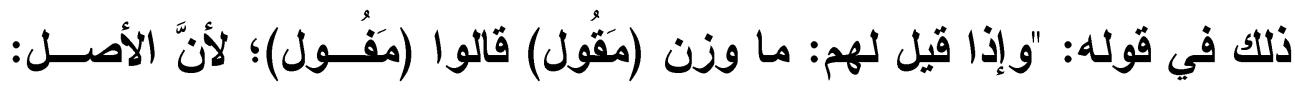

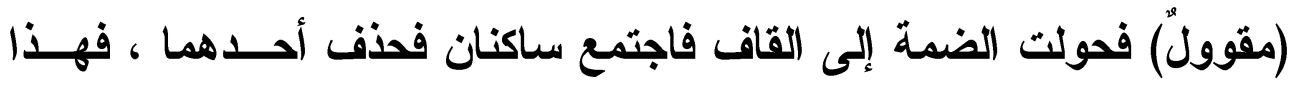

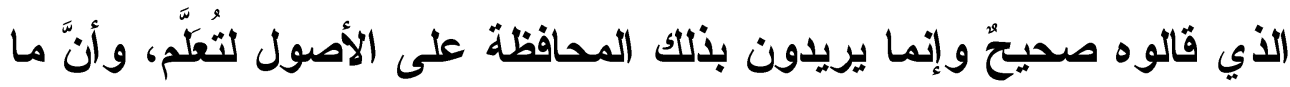

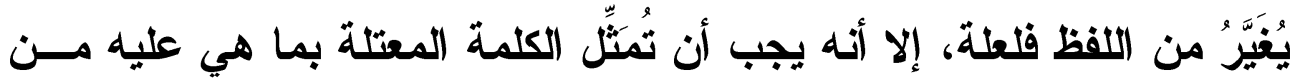

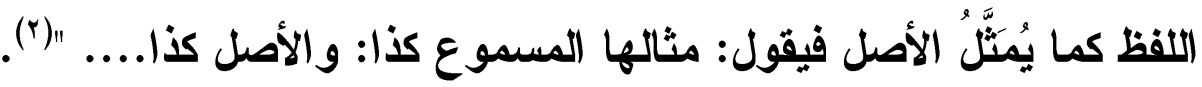
: شذوذ الإصطاح

بدا لي شذوذ في استخدام المصطلح النحوي في كتاب (تعليم العربيــة

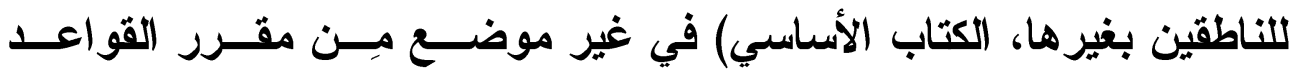
النحوية، أخص بالذكر منه أربعة مصطلحات مرتبة وفق ورودها في الكتاب فوفاب الأساسي وهي: (الوصف، وعطف النست، والخفض، وواو المصاحبة).

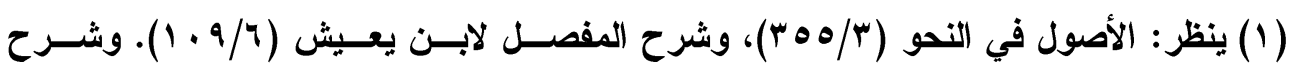

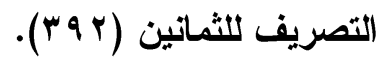

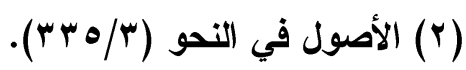



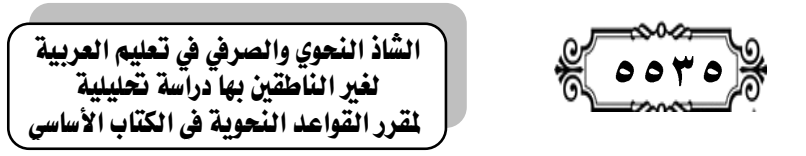

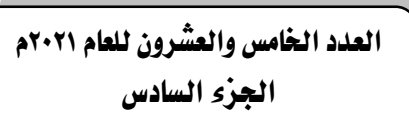

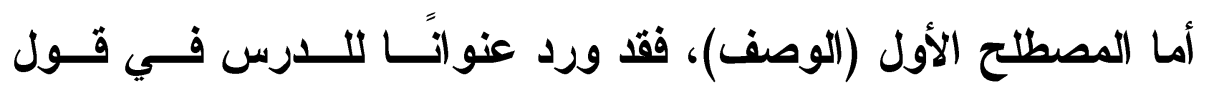

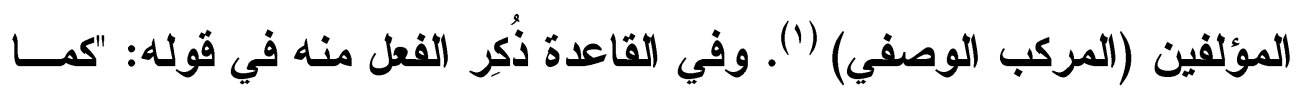

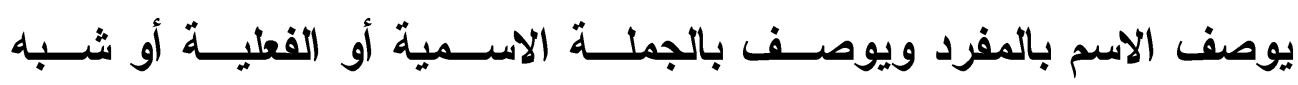

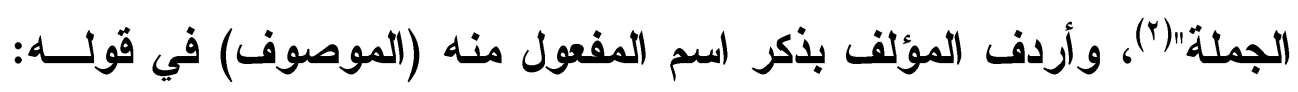
(يلزم في الموصوف بالجملة) وقوله: (... يعود على الموصوف) (r).

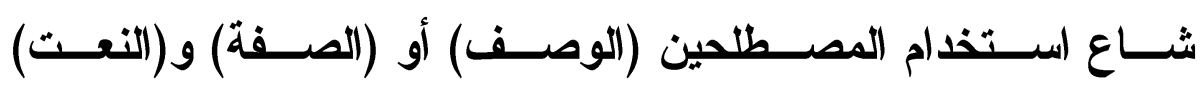

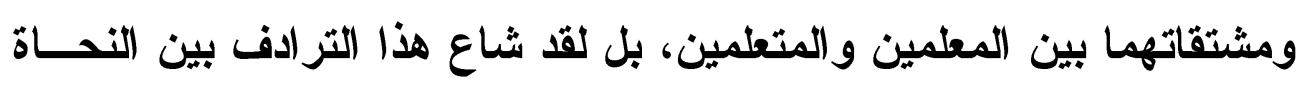

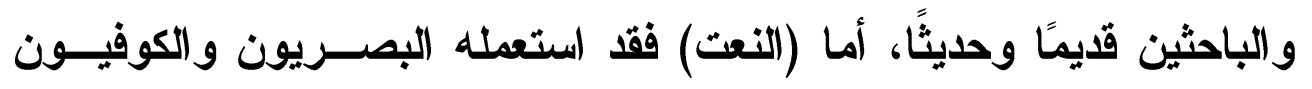

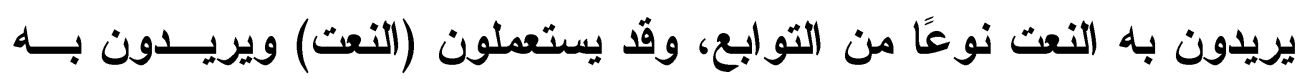

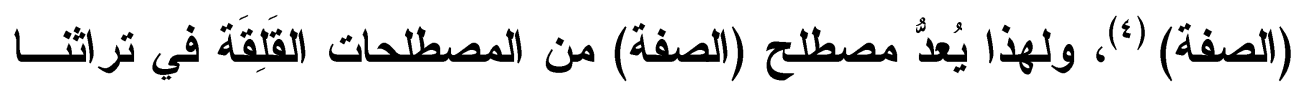

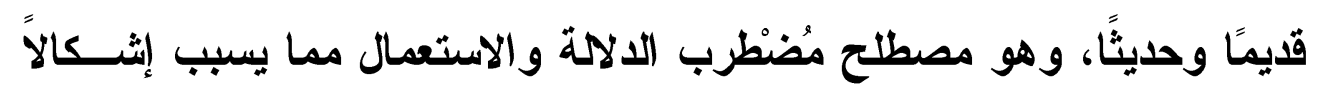
ولبسًا و إرباكًا للمتعلمين. وهن.

هذه القضية تثير إلى تعدد الدلالة للمصطلح الواحد في التعبيـر عـن التصن

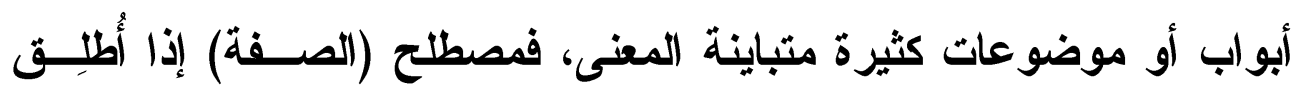

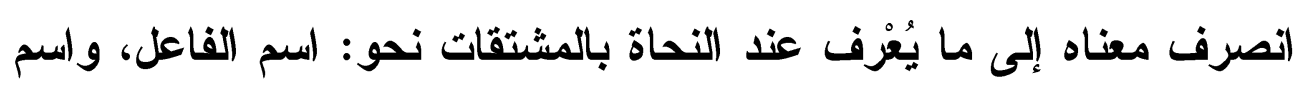

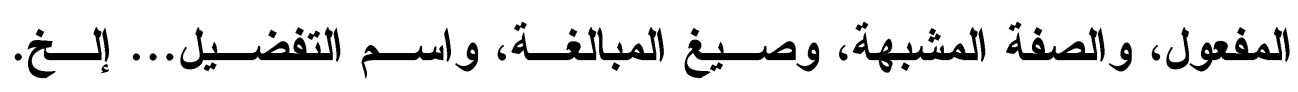

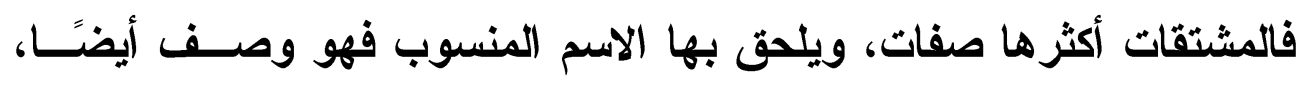

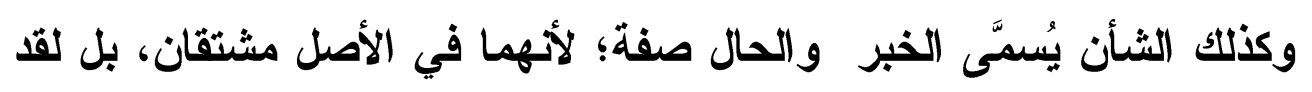

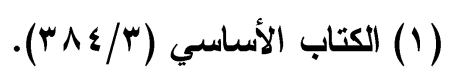

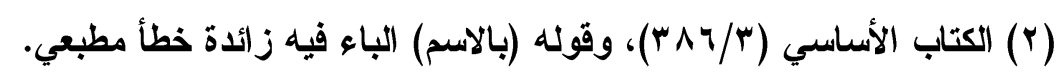

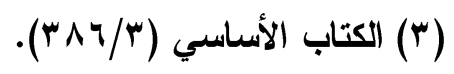

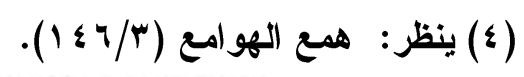


أطلق سيبويه على (التوكيد) صفة(1)، وكذلك ذكر سيبويه (الحال) وأراد به

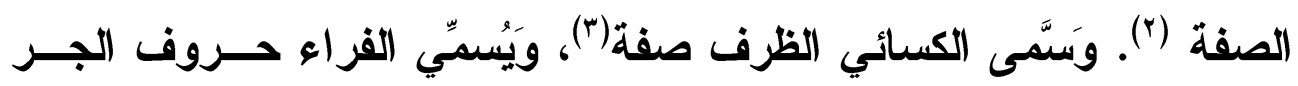

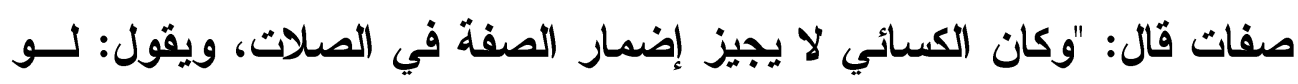

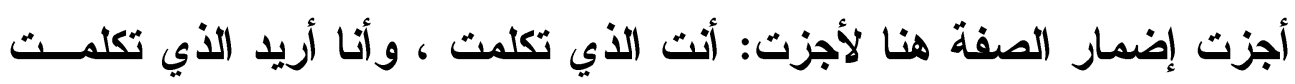

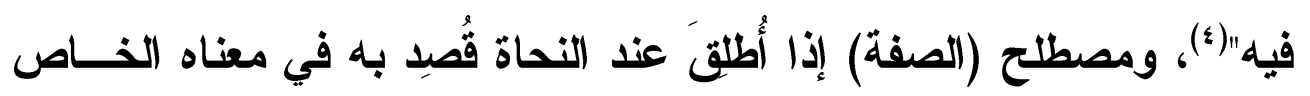
الالالة النحوية في باب التوابع.

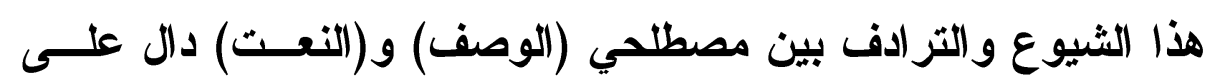

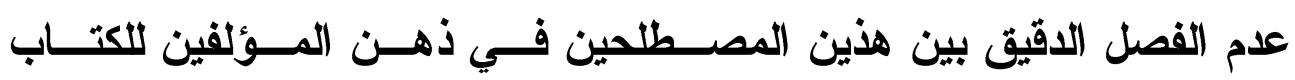

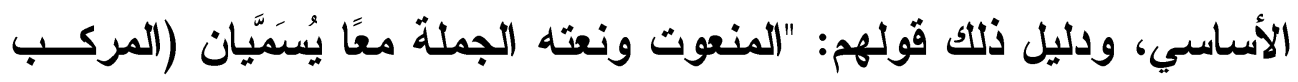

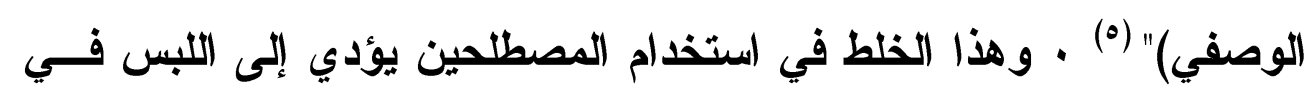

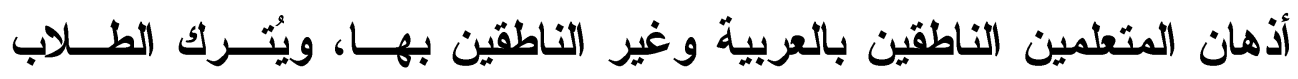

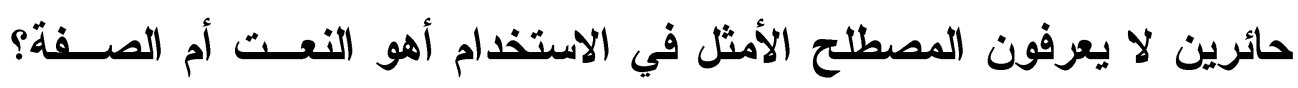

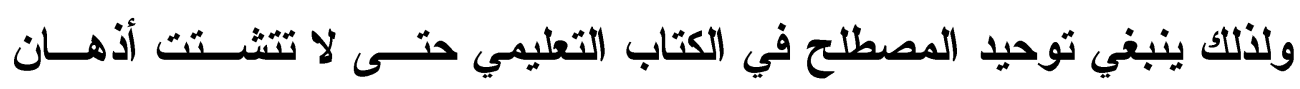

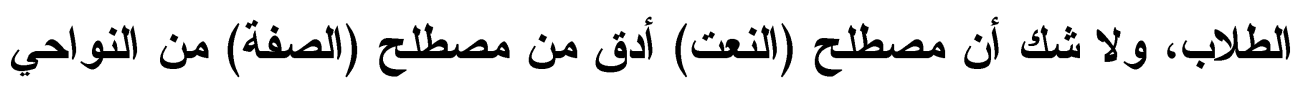

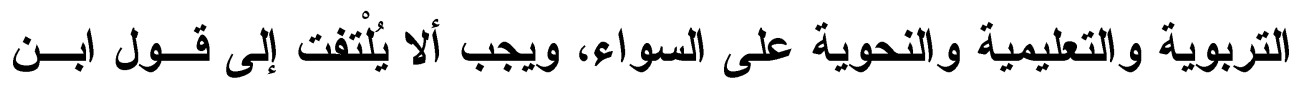

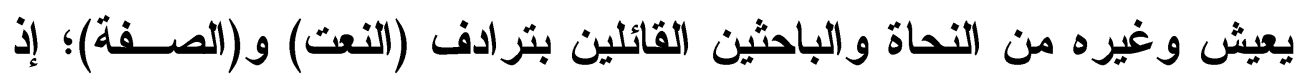

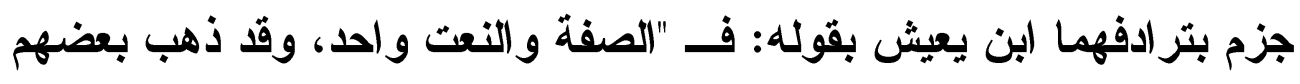

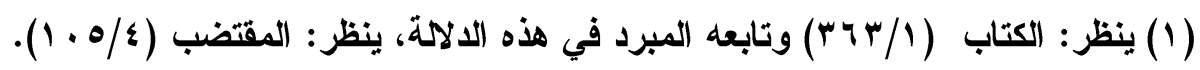

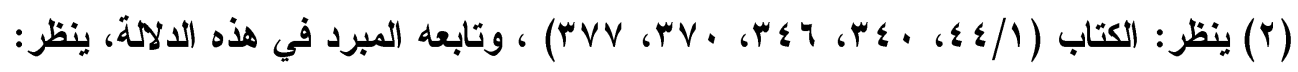

$$
\begin{aligned}
& \text { المقتضب (1) (177) (17). }
\end{aligned}
$$

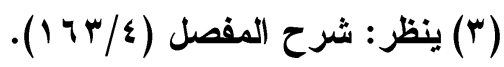

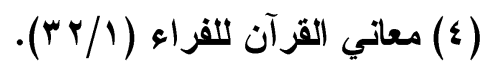

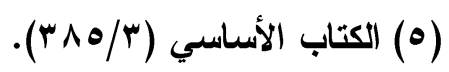




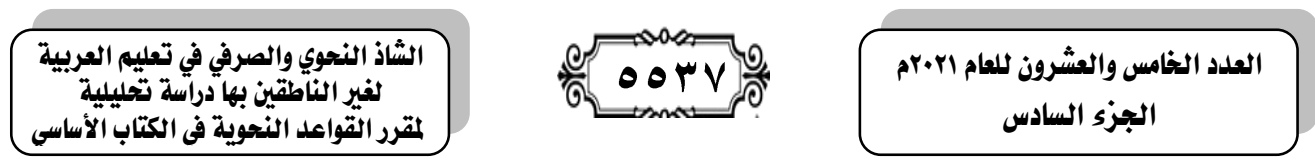

إلى أنَّ النعت يكون بالحلية، نحو (طويل، وقصير) و الصفة تكــون بالأفعـال

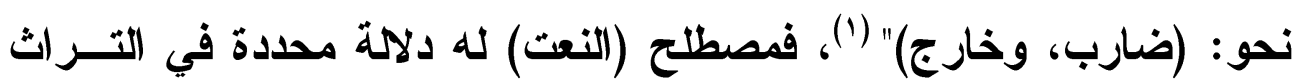
النحوي بخلاف مصطلح (الصفة) المتعدد الدالات على (المشتيقات والخبـر و التوكيد والحال و الظرف، وحروف الجر ... إلخ).

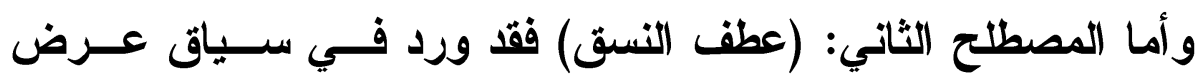

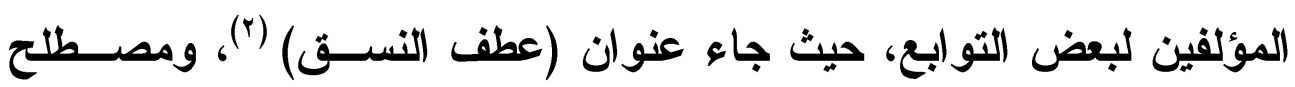

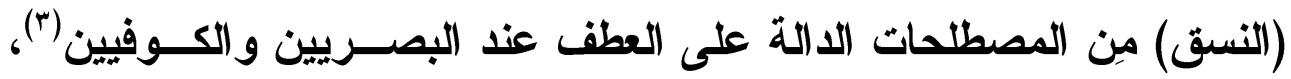

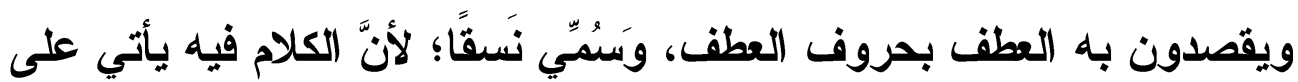
نظام ونسق واحد، ولحاجته إلى حروف العطف، وبهذا يخرج عطف البيــان

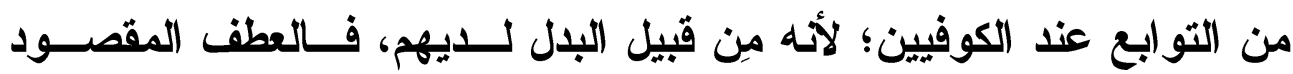

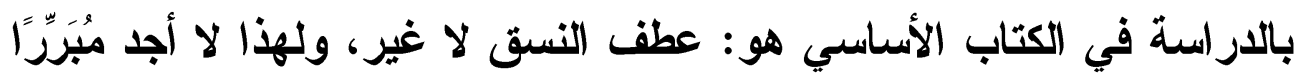

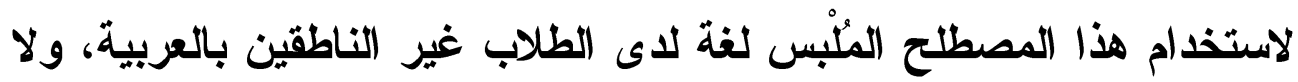

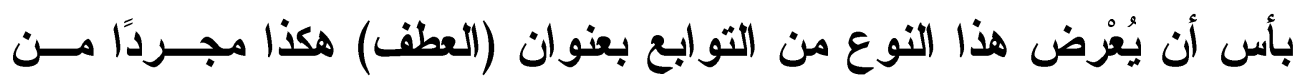
القيد، أو بمصطلح (العطف بحرف) وهو مصطلح تراثي أصيل واضح الدالائ

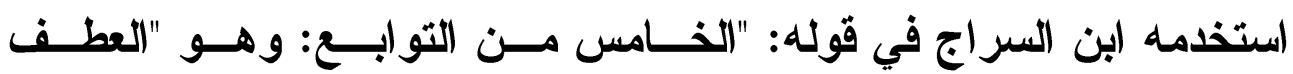

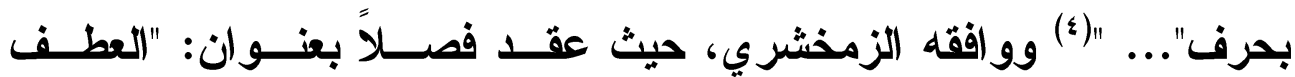

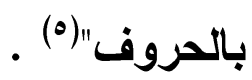

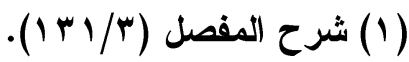

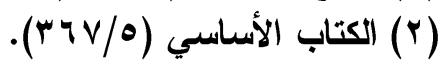

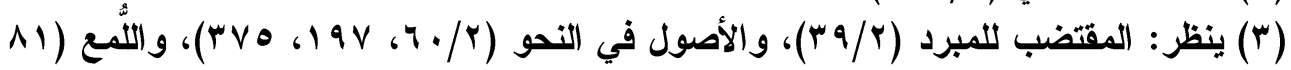

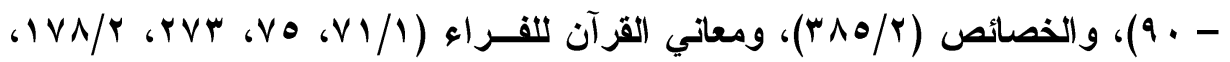

$$
\begin{aligned}
& \text { 1) }
\end{aligned}
$$

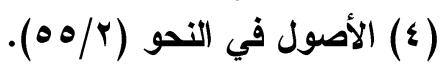

$$
\begin{aligned}
& \text { (0) المفصل في صنعة الإعراب (17) (17). }
\end{aligned}
$$


وأما المصطلح الثالث (الخفض) فقد ورد في موضـعين فـي سـياق

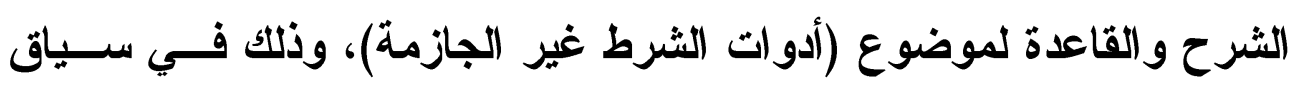

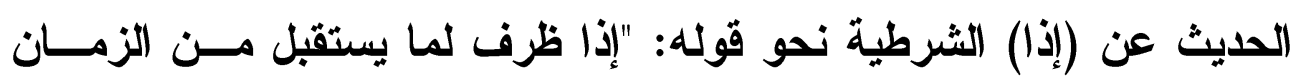

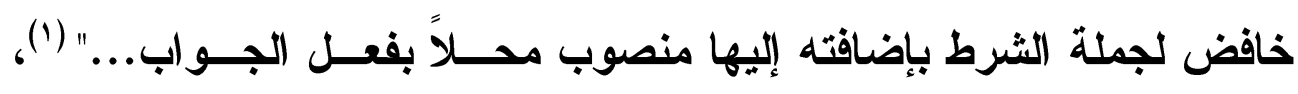
وَمُشْكل هذا المصطلح لاى الطلاب غير الناطقين بالعربية برجع إلى تثثاكله مع مصطلح (الجر) المعروف لايهم بعد حروف الجر والظروف والتوابع...

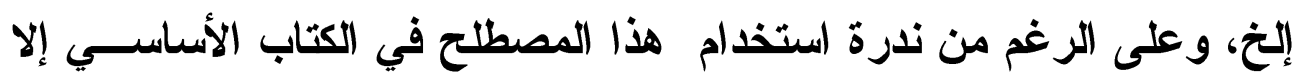

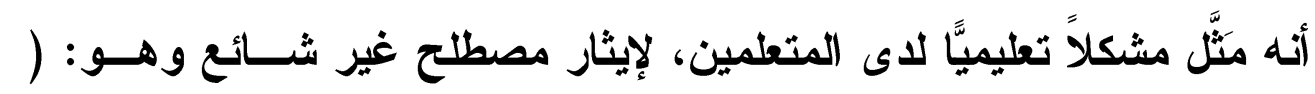

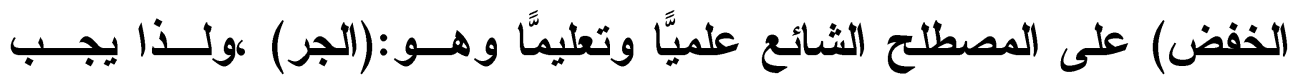

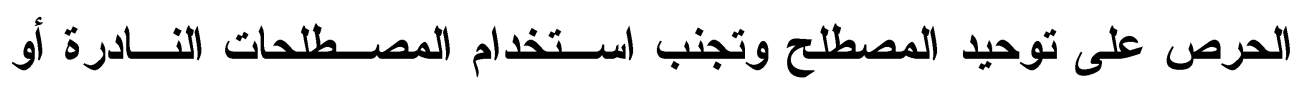
المر ادفة. أما المصطلح الرابع (واو المصاحبة) فقد ورد في موضعين في سياق

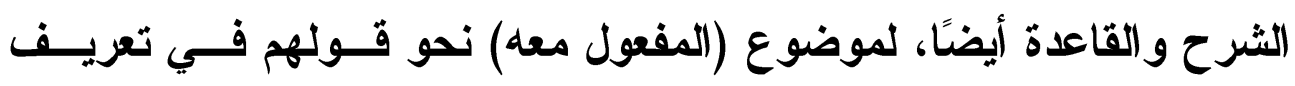

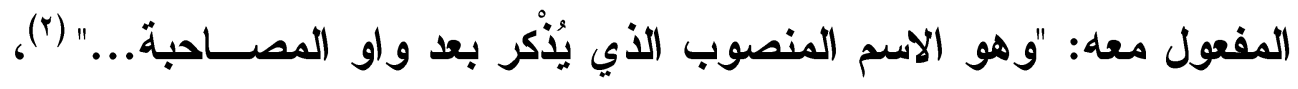
و الإثكال في استخدام مصطلح (واو المصاحبة) يبدو في إعـراب (الــواو)

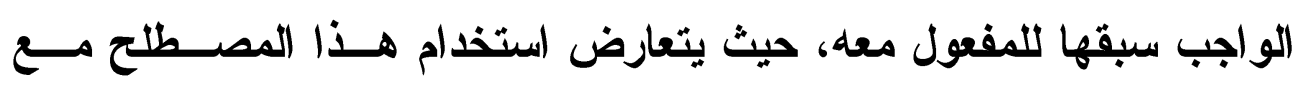

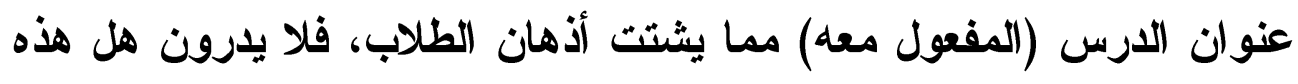

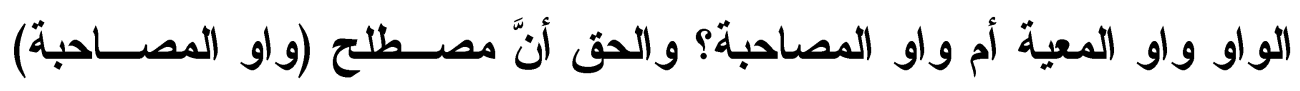

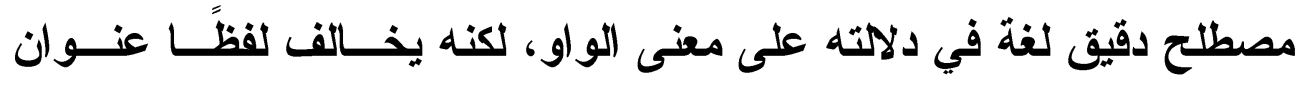

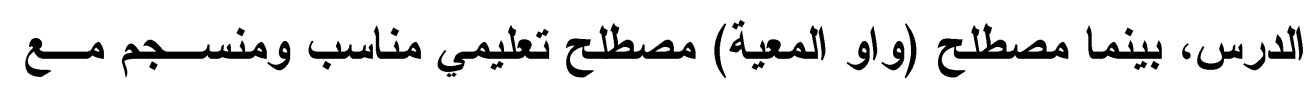

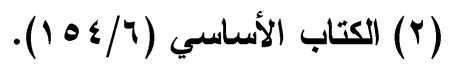




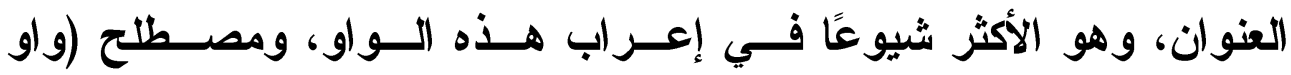
المصاحبة) لم يستخدمه (البصريون مِن سيبويه في القرن الثاني الهجري إلى الى الثي

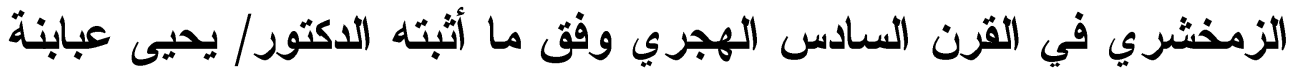

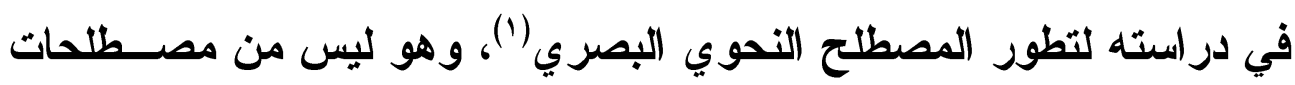
الكوفيين أيضًا، لكنه مفهوم من تقدير هم للفعل الناصب للمفعول معه بإضمار فعل تقديره (لابَسَ، أو صنَاحب) ونحوهما من من الأفعال. r - r - بذوذ الاختيار: - لثذوذ الاختيار وجهان في الكتاب الأساسي: الوجه الأول: (شذوذ في اختيار الموضوع كله) ولهذا الوجه مثــالان و واضحان:

أولهما: اختيار موضوع (الاشتغال) (ץ) حيث استظهر المؤلفون أركــان

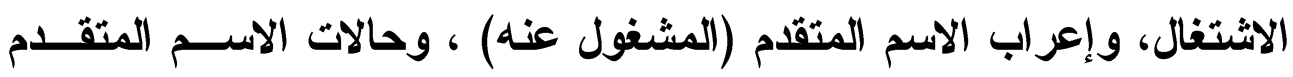

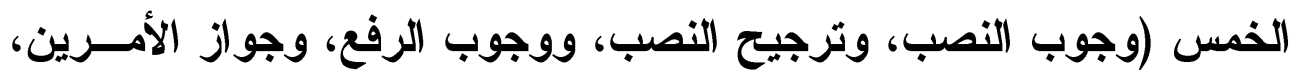
وترجيح الرفع). أما المثال الثاني: فيتمثل في اختيار موضوع (الصفة المشبهة باســـ

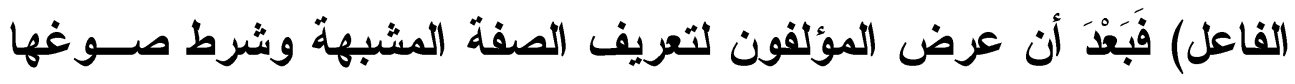
ذكروا الأوزان التي ترد عليها الصفة المشبهة، وذلك كما يلي: "ا - الصفة المشبهة: اسم مشتق لمن قام بالفعل على وجه الثبــوت

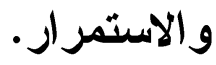

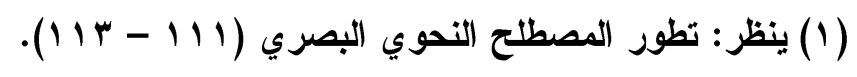

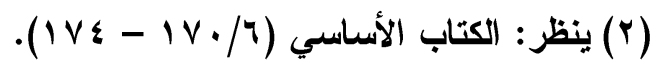




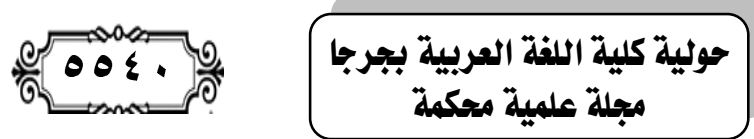

r - עا تصاغ إلا من الفعل الللام الثلاثي.

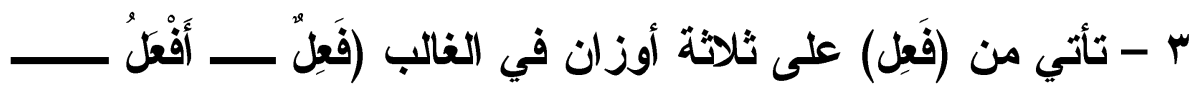

- فَعْنانُن

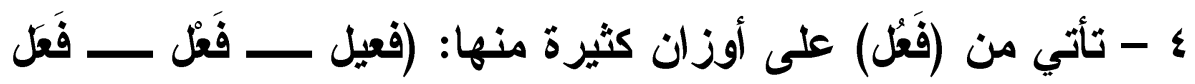

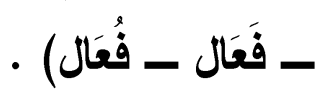

ه - قد تأتي على وزن اسم الفاعل من الثلاثي (قاعل)" (').

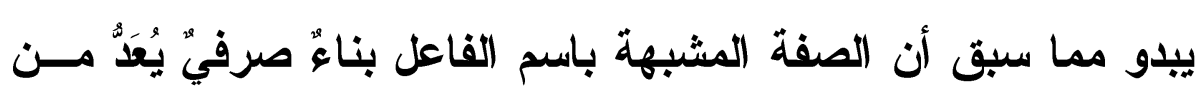

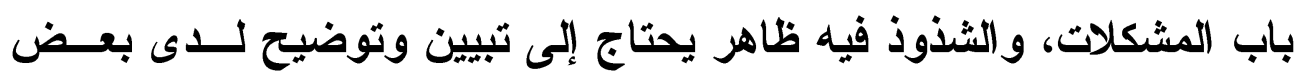
المختصين، ناهيك عن الطلاب الناطقين بالعربية وغير الناطقين بها، وأظهر ولئه

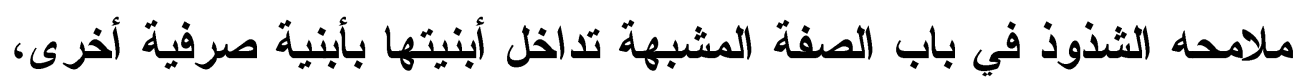

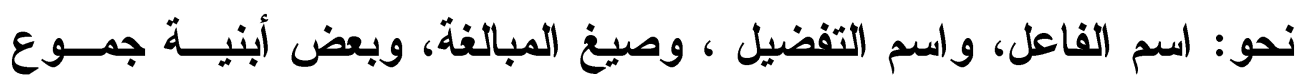

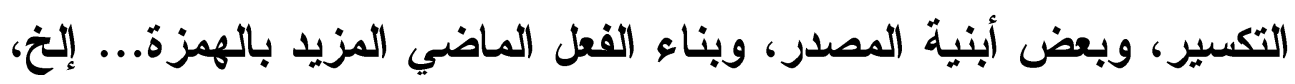

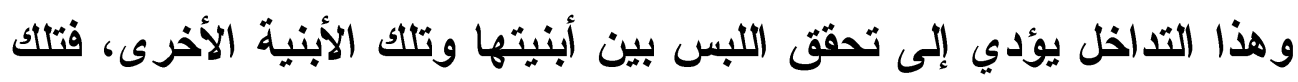

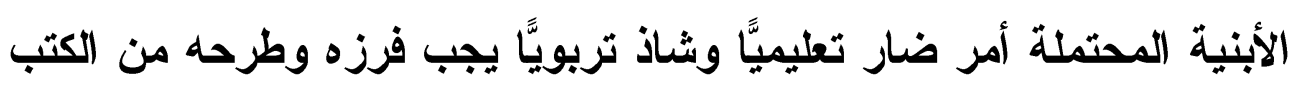

التعليمية.

الوجه الثاني (ثذوذ في اختيار مفردات الموضوع الواحد)، ومثال ذلتك ما ورد في سياق الحديث عن الاستثناء في موضوع (إعراب المستثنى بخلا

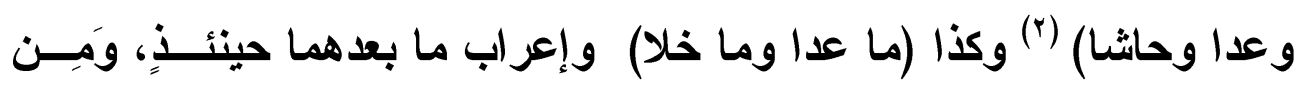

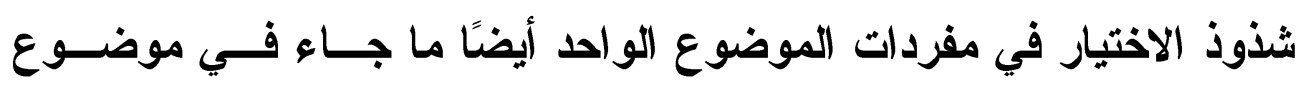

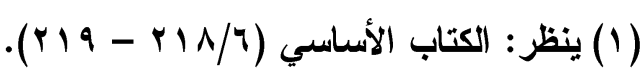

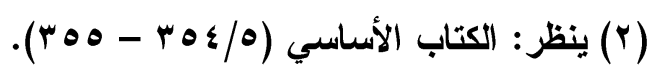


(الحال الجامدة) (') وتقسمها إلى حال جامدة مؤولة بالمشتق وحال جامــدة

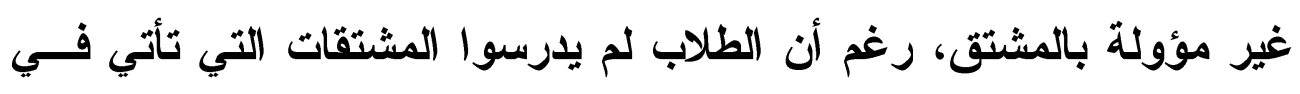

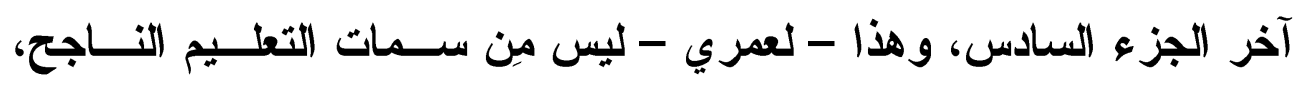

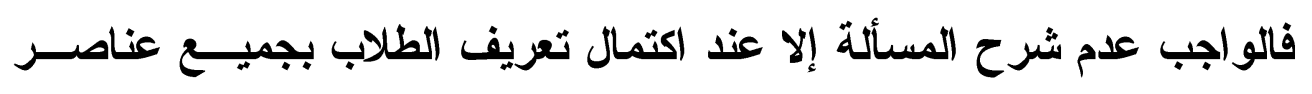

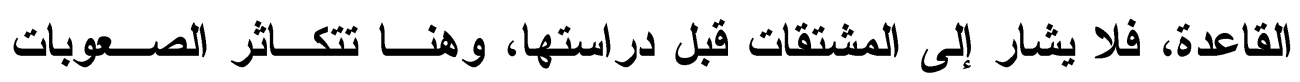

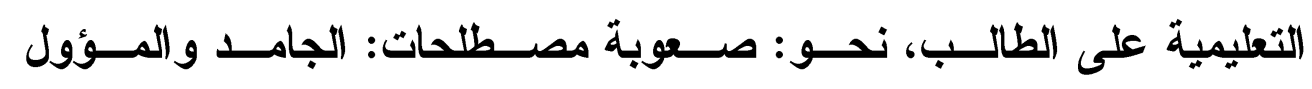
والمشتق... إلخ.

ومن مظاهر الثذوذ في اختيار مفردات الموضوع الواحد أيضًا ما جاء

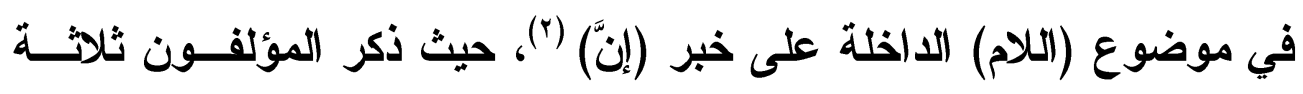

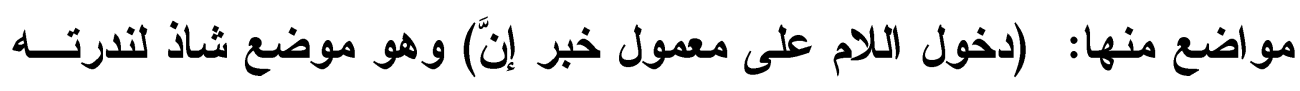

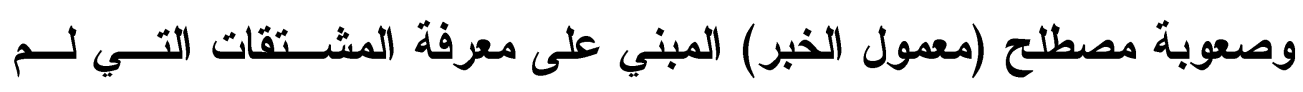
تدرس بَعْدُ، وشروط إعمالها عمل أفعالها. شذوذ الاختيار بوجهيه السابقين شذوذ كمي دال على رؤى المــؤلفين

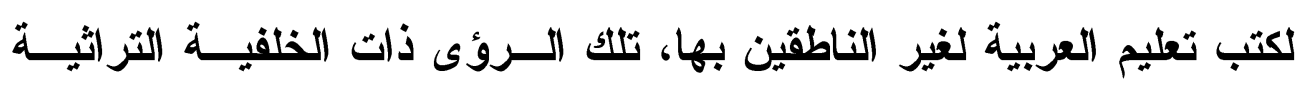

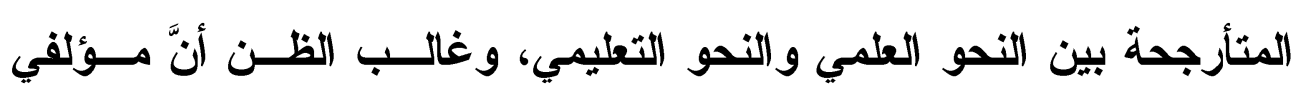

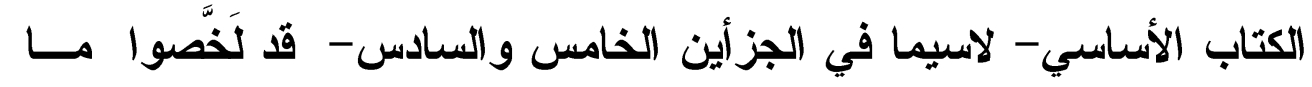

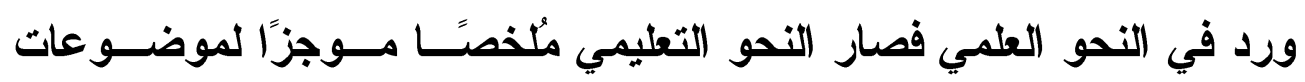

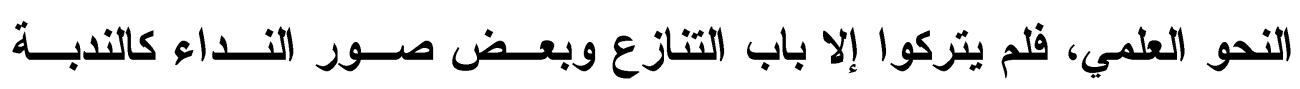

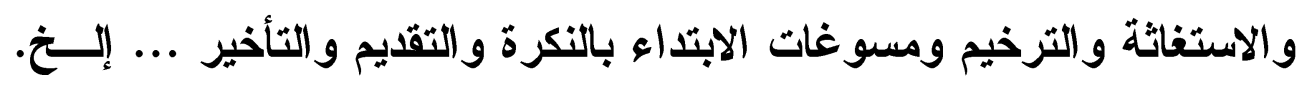

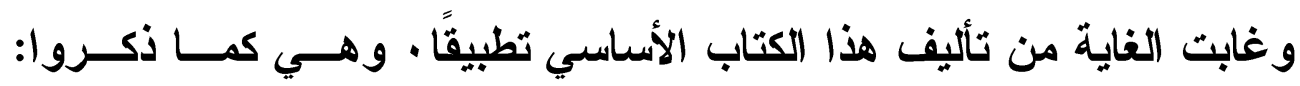

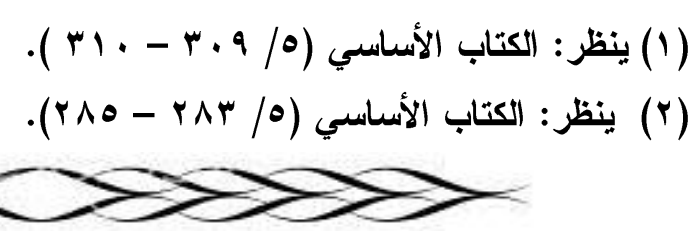


"ووسيلة الكتاب للوصول إلى هذه الغاية اختيار مقصــود للمحتـوى بحيـــ

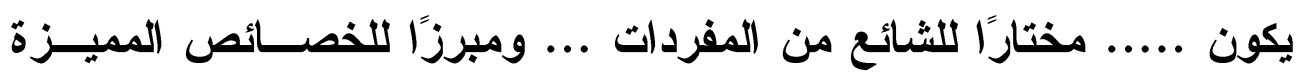

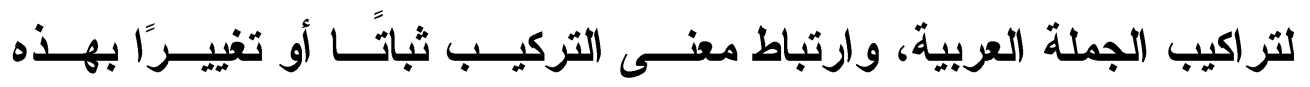

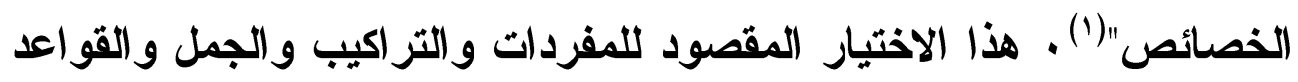

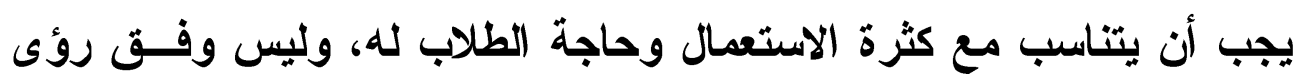

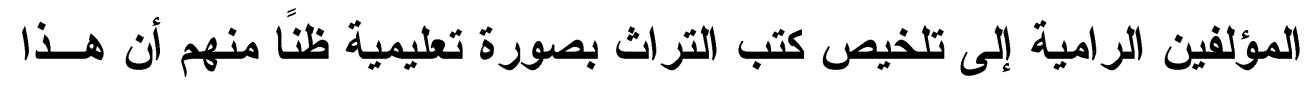

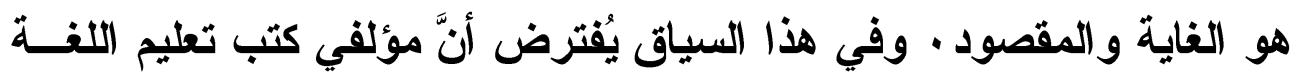
العربية لغير الناطقين بها يعمدون إلى الإحصـائيات المتخصصـــة معيــارًا

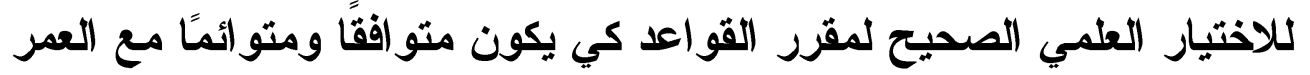

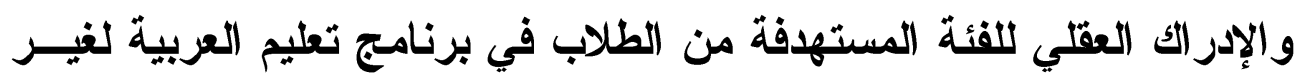
الناطقين بها.

\section{؟ - شذوذ الاحتمال:}

اللغة حمالة أوجه، وتعدد الأوجه في التحليل النحوي لتراكئ اكيب العربيــة

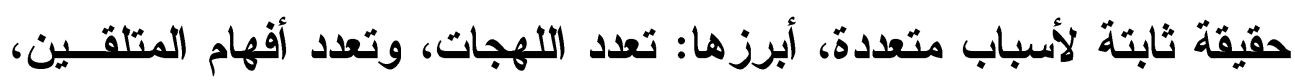
و المعطيات السياقية.... إلخ، وحصر الأوجه الممكنة وغير الممكنة و التعليـلـل

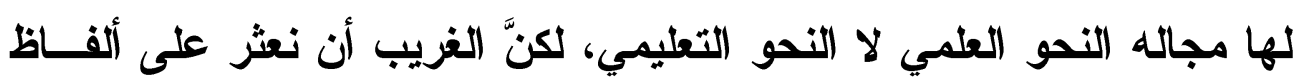

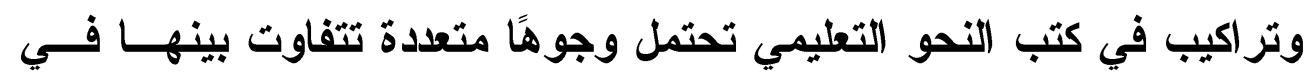

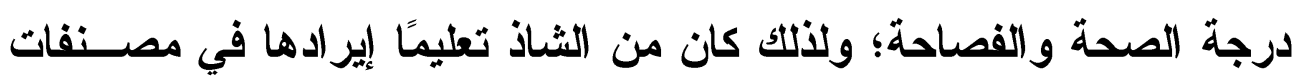

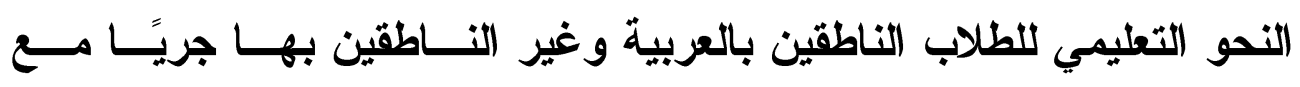
مقتضى ما تعارف عليه النحاة من قولهم: "الاليل متى تطرق إليه الاحتمــال لم يصلح للاستدلال". 

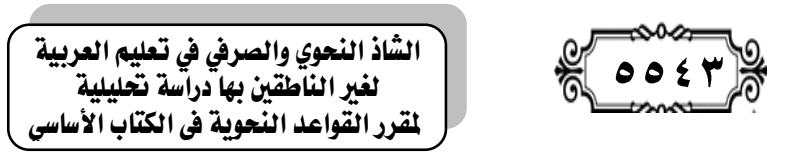

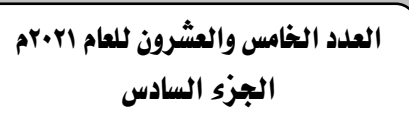

وشذوذ الاحتمال لاى الطلاب غير الناطقين بالعربية مما يجب تجنبه ،

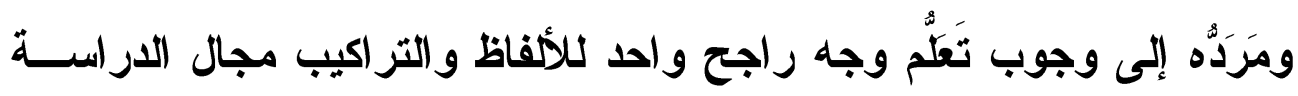

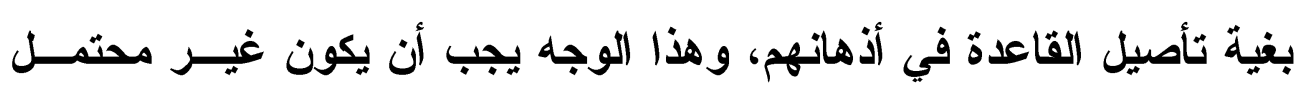

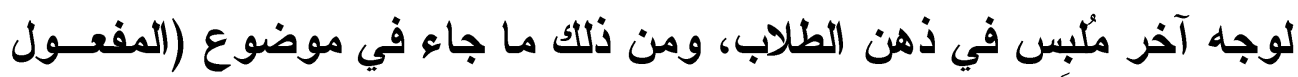

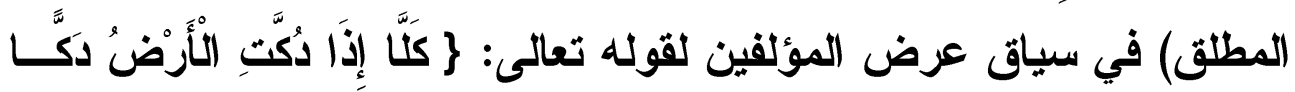

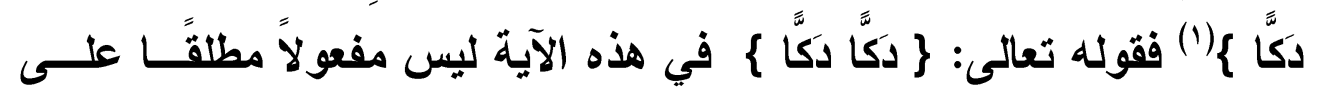

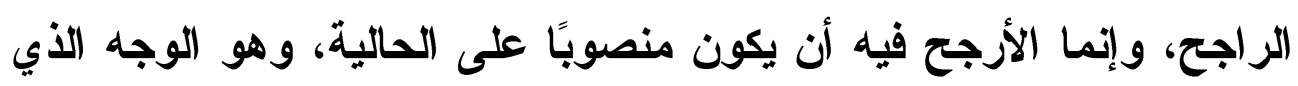

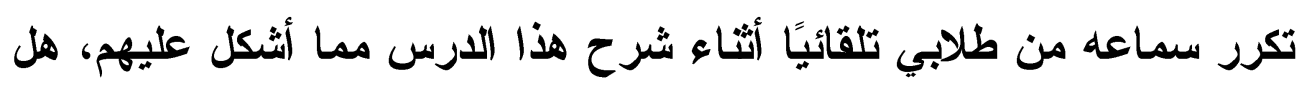
هو حال أم مفعول مطلق؟ فهذا اللفظ محتمل لوجهين ذكرهما السمين الحلبي

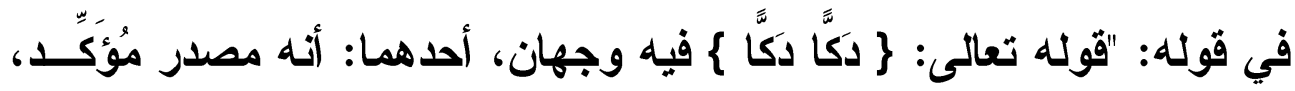

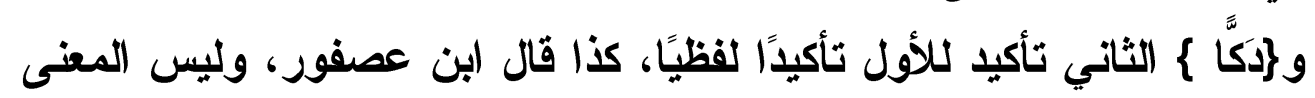

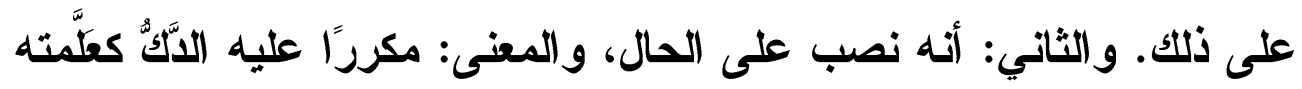

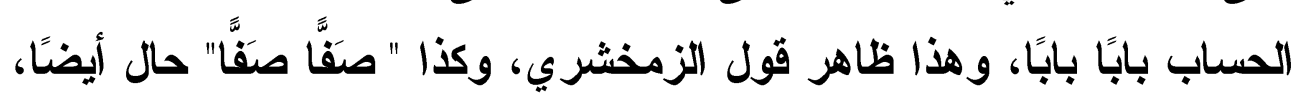

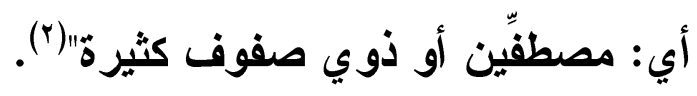

وقد تكون نظرة المؤلفين إلى بعض الأمثلة والتــدريبات شـــلية دون

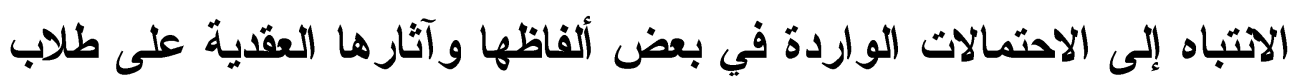

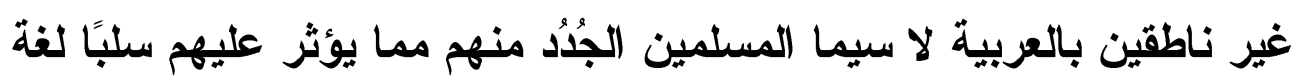
وعقيدة، وذلك نحو ما أورده المؤلفون في موضوع الاستثناء حيث اختاروا

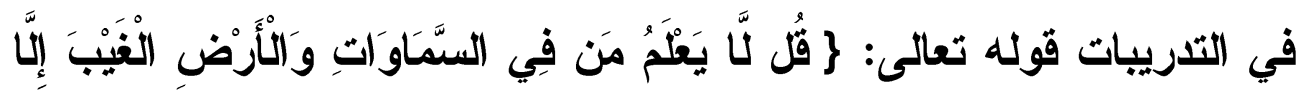

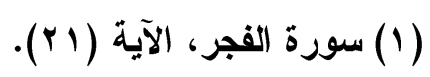

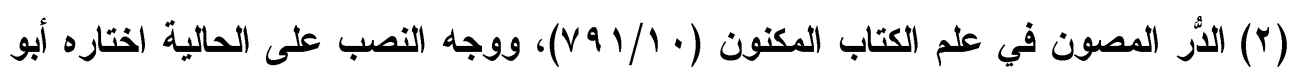

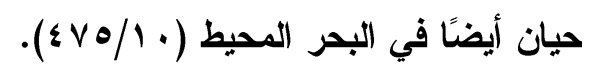




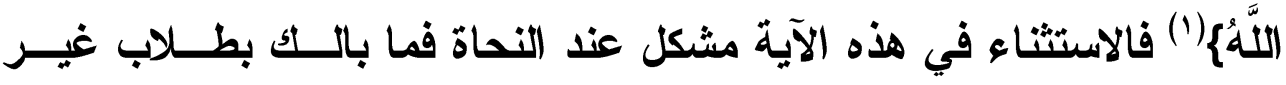

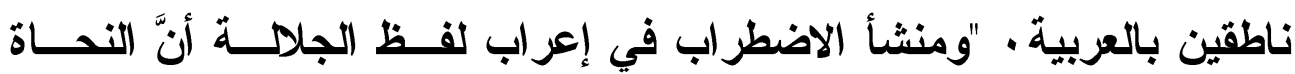

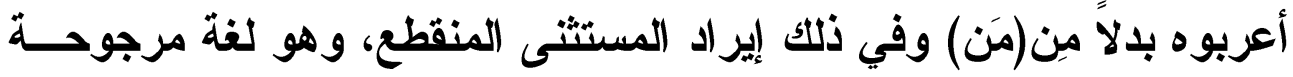

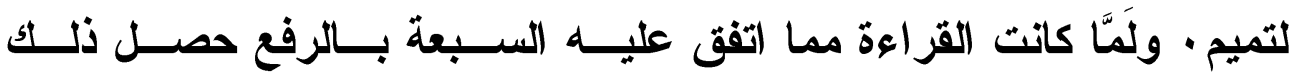

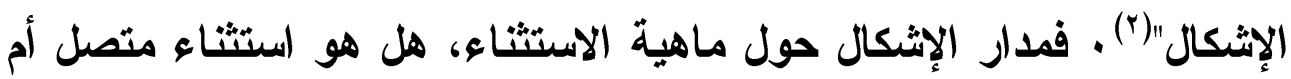

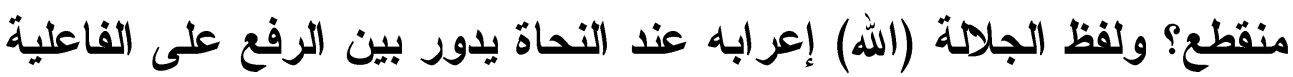
لــ (يعلم) و الرفع على الابتداء وخبره محذوف.

والحق الأي لا مراء فيه أن موضوعات النحو التعليمي يجب أن تكون

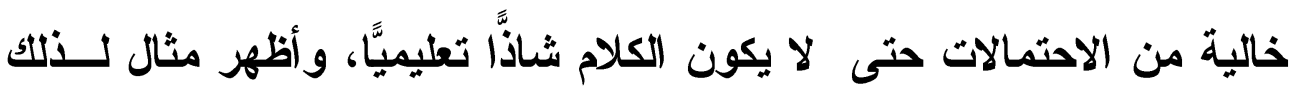

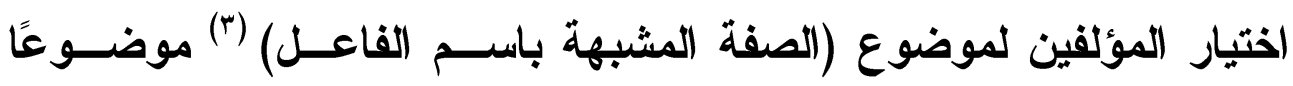

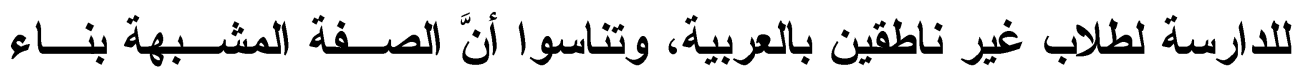

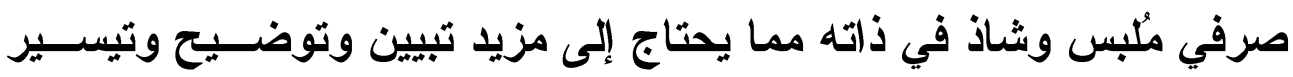

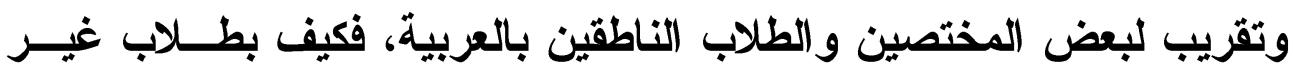

ناطقين بها؟

و إذا ألقينا نظرة أولية على الصيغ التي أوردهـــا المؤلفــون للصــفة

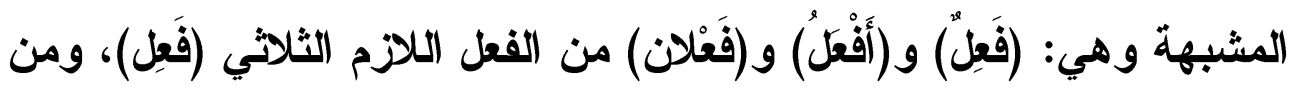

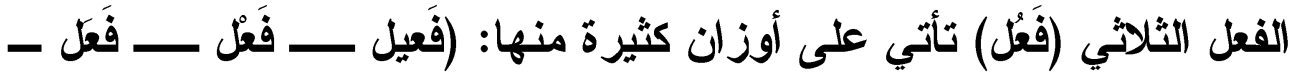

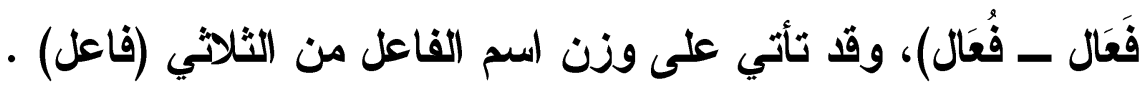

(1) (1) سورة النمل، الآية (10).

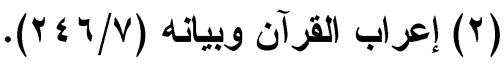

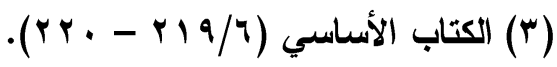


بعد استعر اض الأبنية التي ترد عليها الصفة المشــبهة كمـــا أوردهـــا

المؤلفون يبدو وقوع اللبس والاحتمال والثذوذ بين الصفة المشبهة وصيغ المبالغة نحو صيغة: (قَعيل): (رحيم): صفة مشبهة إذا اثشتقت مسن (رَهُمـم) وَتكون صيغة مبالغة إذا اثتثتَ من (رَحِمَهَ)، ونحو صيغة (فَعْلان): رحْمَن: صفة مشبهة إذا اثثتثت من (رَحُم)، وتكون صيغة مبالغة إذا اثــتقت مسن (رَحِمَهَ)، وهكذا · وَمَن الأبنية المتماثلة الصفة المشــبهة والمصــدر بنــاء

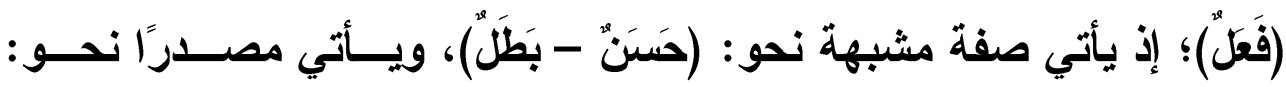

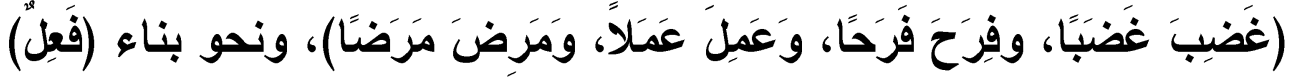
يأتي صفة مشبهة نحو: (فَرحُ، وَغَضِبَّ) ، ويرد مصدرًا نحو: (لَعَبَ: لَعِبًا)، وتلك المشابهة الحاصلة بين أبنية الصفة المشبهة وغيرها لا تقتصر علىى ذلك ، بل ترد متثابهة مع أبنية اسم القاعل واسم التفضيل وبعـض صــيغ جموع التكسير ... إلخخ موأكتفي هنا بالإثـارة الســابقة؛ فالســياق لا يقبـلـ المزيد من التفصيل و البيان.

\section{0 - شذوذ التلازم والاقتزان:}

التتلازم والاقتران: بين مركبين أو ركنين من أركــان الجمـــة، أصــلـ تعليمي تجب مراعاته في كتب النحو التعليمي، وهو أصل حرص المؤلفــون للكتاب الأساسي على الالتز ام به ، نحو ما جاء في بعض العنــاوين، نحـــو: (المركب الوصفي، والمركب الموصولي، والمركب العددي)، لكنهم لم يُنِمهُوا تأصيل تلكك العناوين في المركبات المناظرة لها، وفي هذا السياق أثنير إلـى ما جاء في صدر التدريبات الواردة على موضوع (أفعال المقاربة) (1) حيــث 
طلب المؤلفون للكتاب الأسساسي من الطلاب غير الناطقين بالعربيــة تعيـين

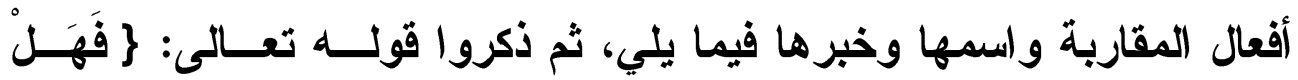

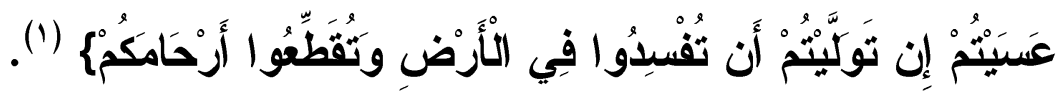
في هذه الآية جاء التركيب أو الأسلوب الثرطي مُعترضًا بين الضمير

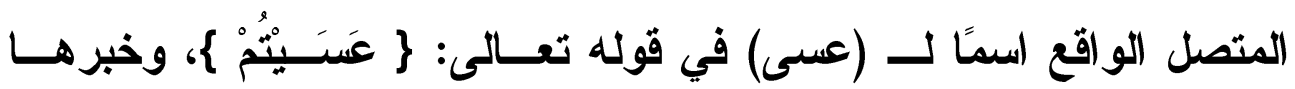

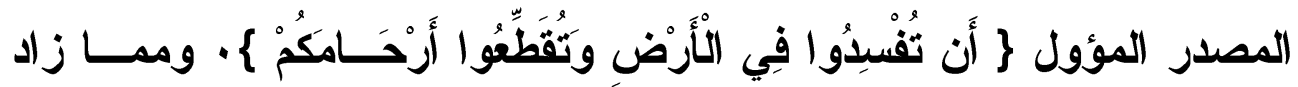

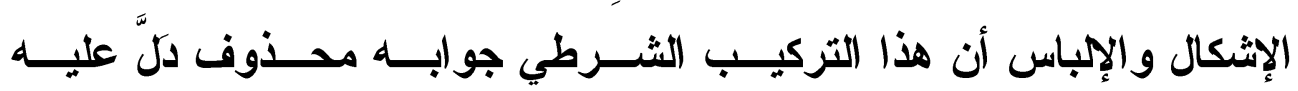

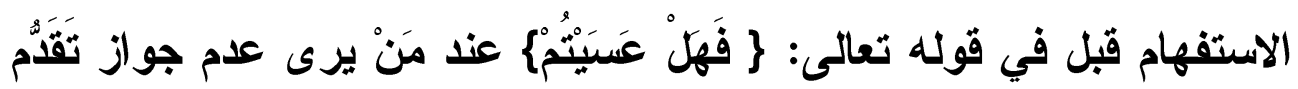

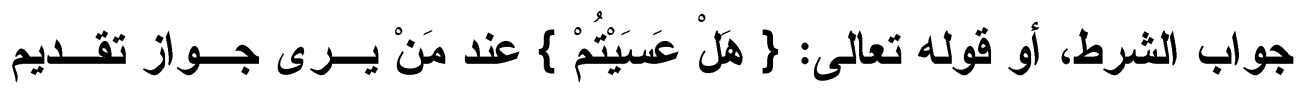

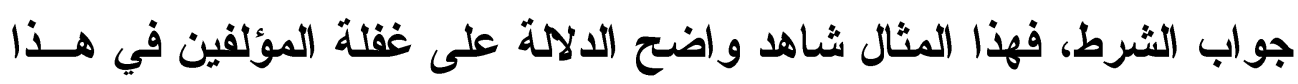

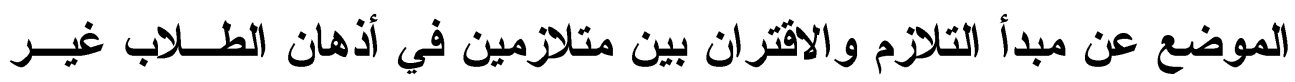

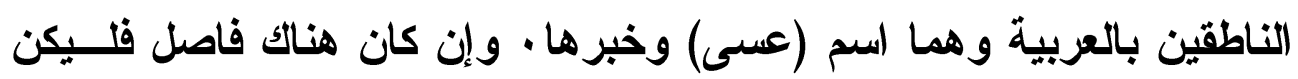

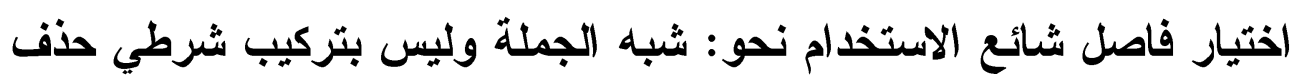

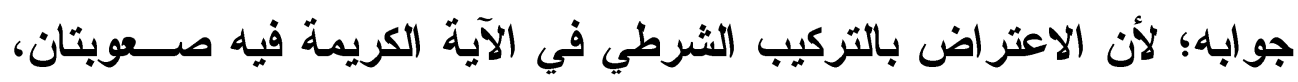

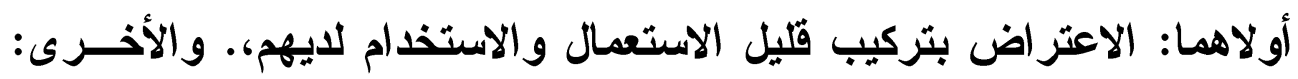
حذف جواب الثرط.

\section{1 - شذوذ الترتيب:}

يلحظ المتأمل في مفردات مقرر القواعد النحوية في الكتاب الأساســي

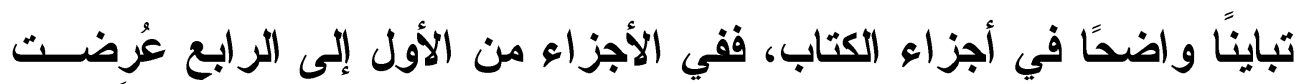

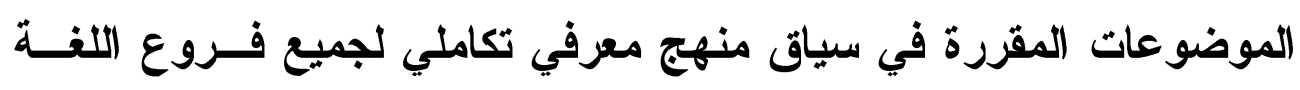


العربية في ظل نصوص لغوية مُؤَّلَفة، أما في الجزأين الخامس والســادس

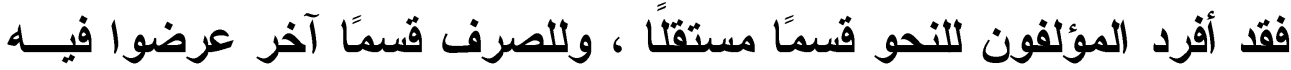

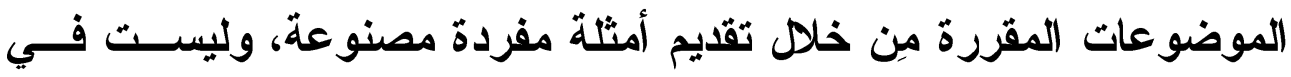

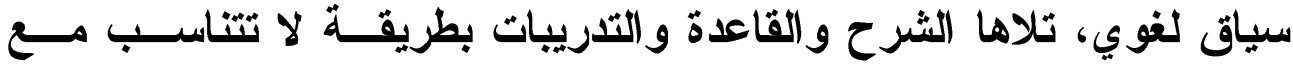

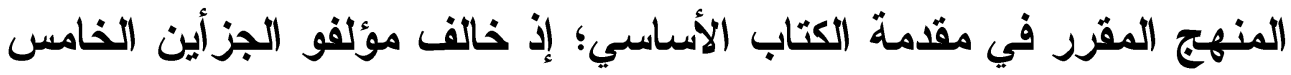
و السادس المنهج المعتمد في مقدمة الكتاب الأساسي، فجعلوا لكل فرع مسن الجن

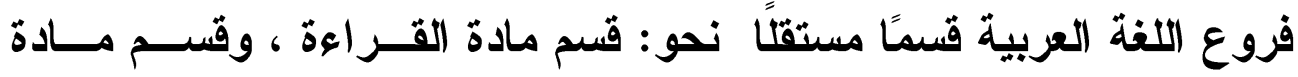
الأدب و النصوص، وقسم مادة النحو ، وقسم مادة الصرف ، وقســم مـــادة

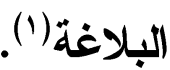

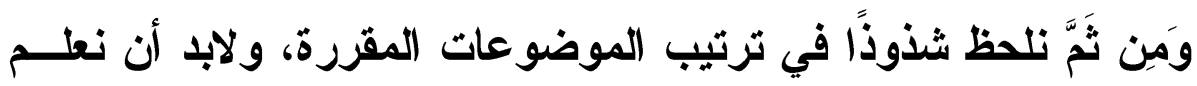

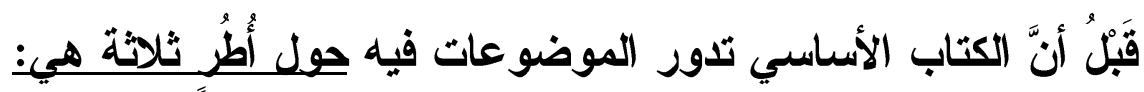
1 - المقدمات النحوية (الكلمات وأنواعها وعلامات الإعراب و البناء.. إلخخ) في الجزأين الأول والثاني المُقََََّين لطِلاب المستوى الابتدائي.

r - التزاكيب والأساليب والجمل العربية، ومن البنى الصرفية عرضوا

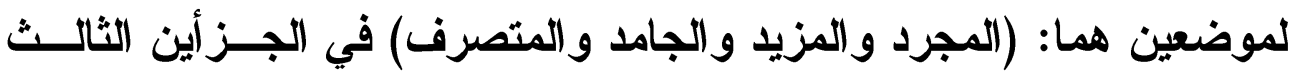

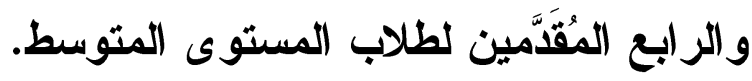

r - بعض الجمل والأساليب العربية، ومــن الموضــوعات الصــرفية

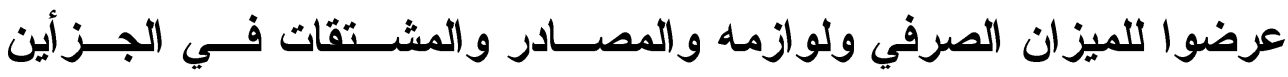

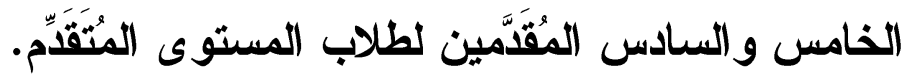

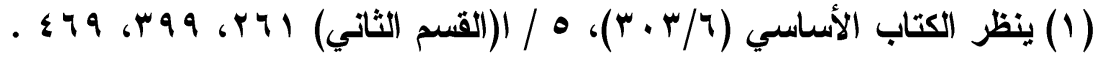




\section{الترقير الدولخ 2356-9050

أما أبرز ملامح شذوذ الترتيب في الكتاب الأساسي فسأعرضها موجزة في نقاط خمس، هي:

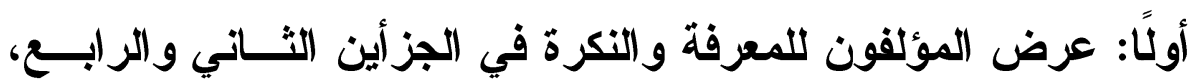

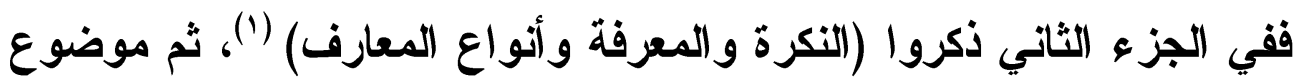

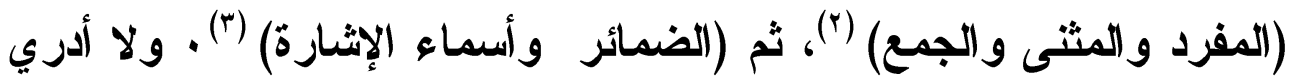
ما المسوغ العلمي للفصل بين المعارف وأنواعها بموضوع (المفرد و المثنى

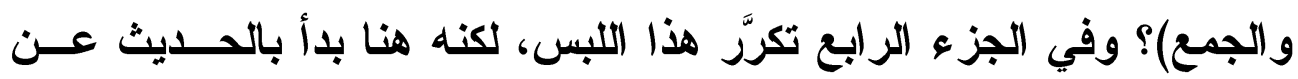

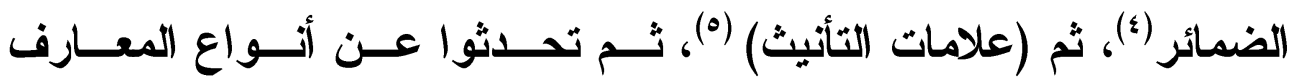

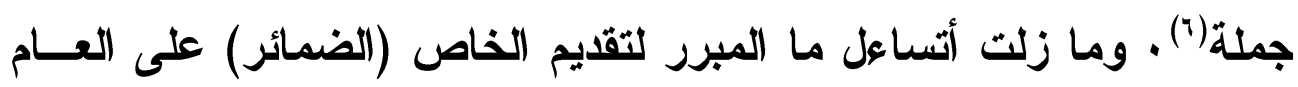

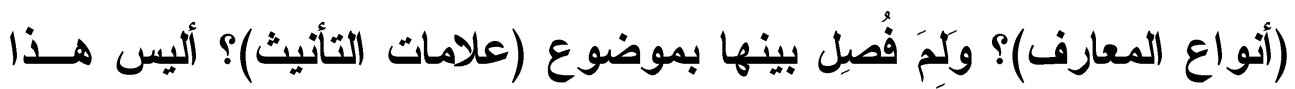
شذوذًا في الثرتيب؟ يُنَفِّر طلاب العربية من الناطقين بها وغير الناطقين بها. ثانيًا: في سياق تناول المؤلفين للجملة الفعلية، بدأ الحديث بمقدمة عن

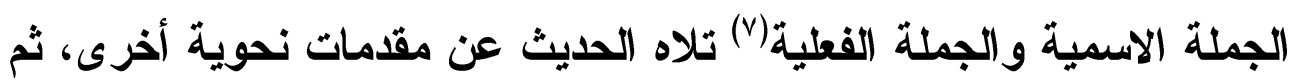

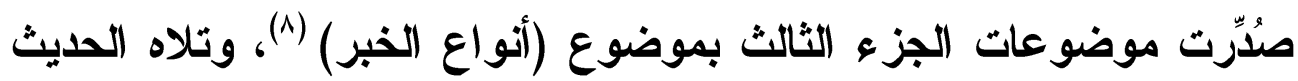

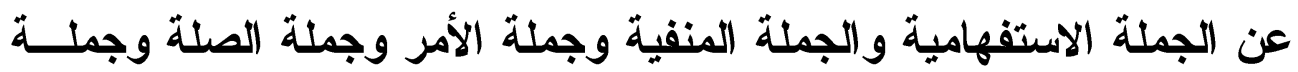

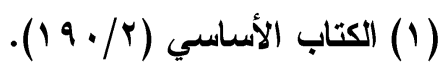

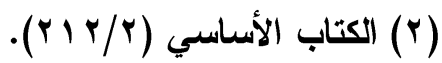

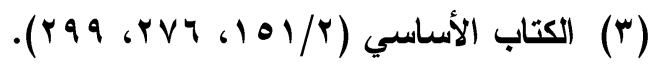

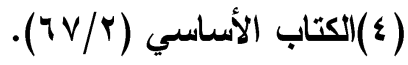

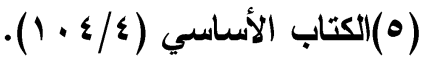

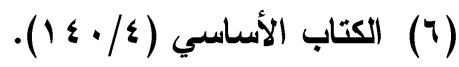

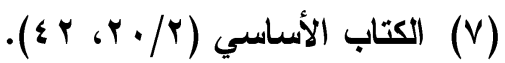

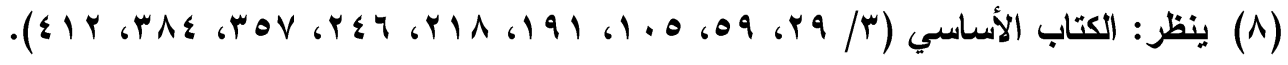


النهي وبعض المركبات، والغريب أنهم عرضوا في هذا السياق درسًا بعنوان

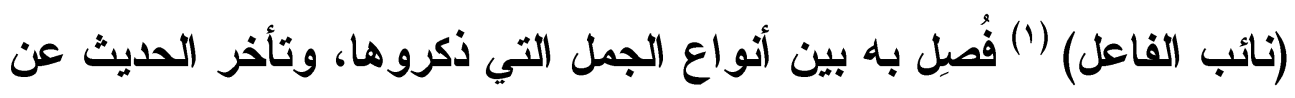

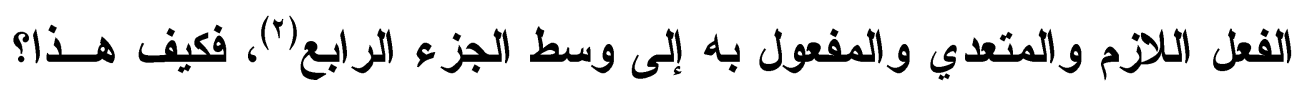

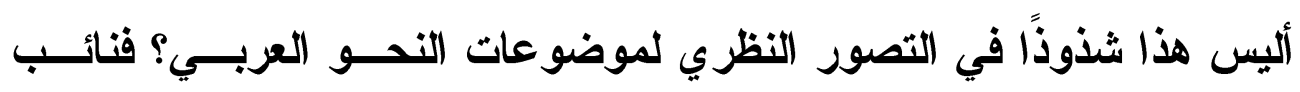

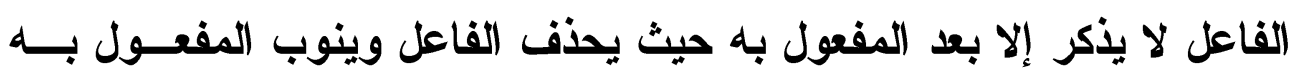

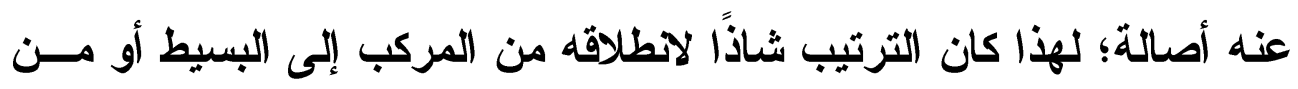
الصعب إلى السهل في عرف النحاة وخلافًا للمنطق الصريح. ثالثًا: وثَمَّة ملمح آخر من ملاح شذوذ الترتيب في سياق تناول الجمل

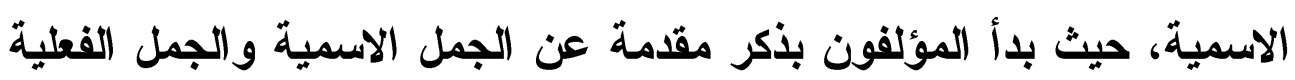

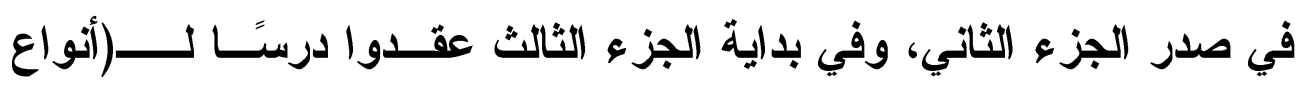

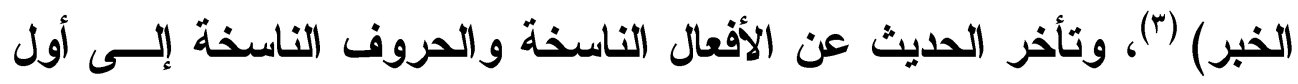

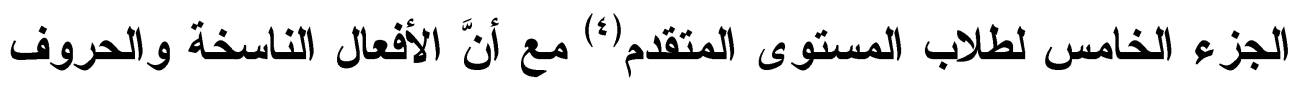

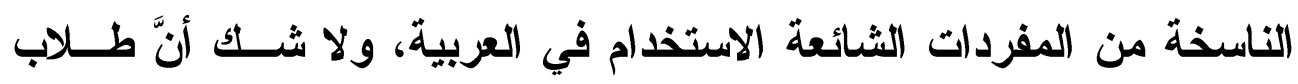

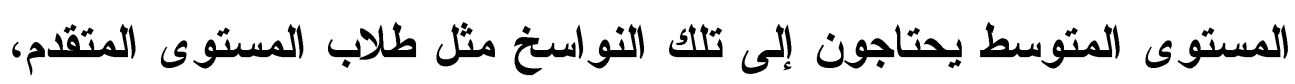

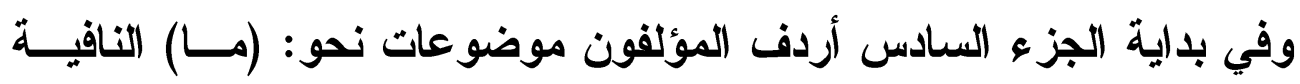

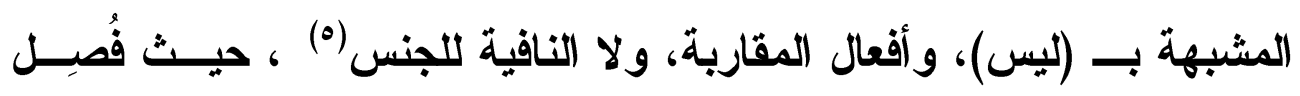

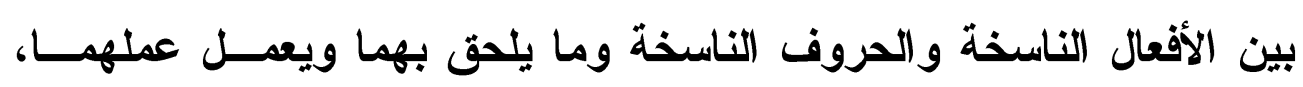

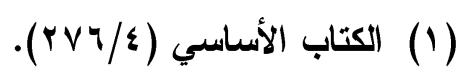

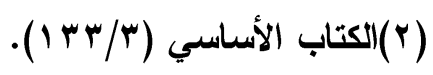

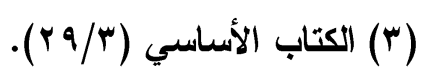

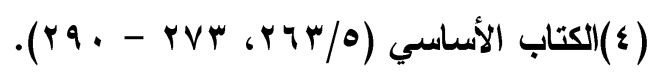

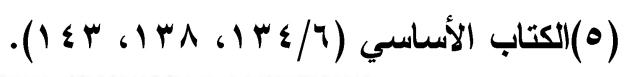


بموضوعات اللازم و المتعدي، وظنَّ وأخو اتها، و أعطى وأخو اتهـا، والحــال

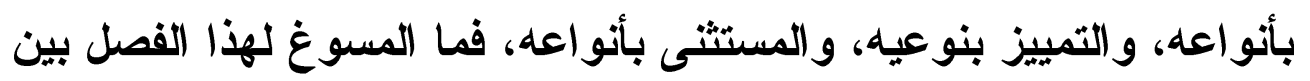
أجزاء الموضوع الواحد؟ أليس هذا شذوذًا في التصور النظري لاعى المؤلفين لنظرية النحو العربي. رابعًا: وفي مجال البنى الصرفية صدَّرّ المؤلفون حديثهم بمقدمة عـن

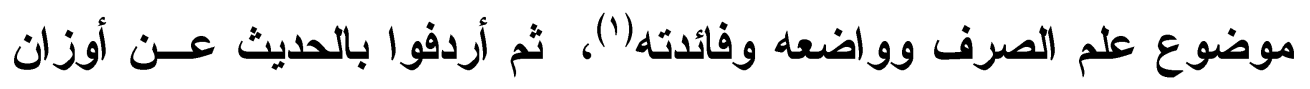

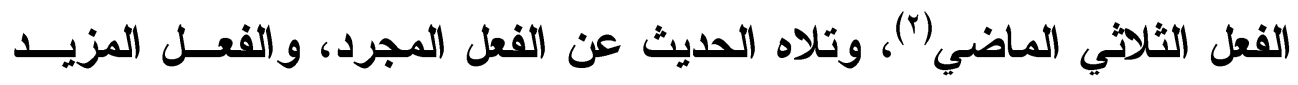

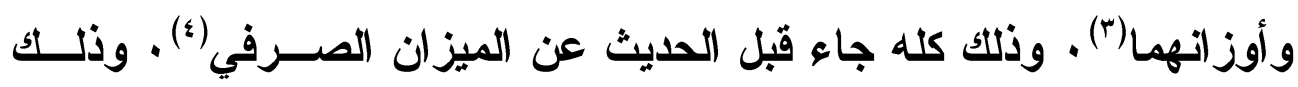

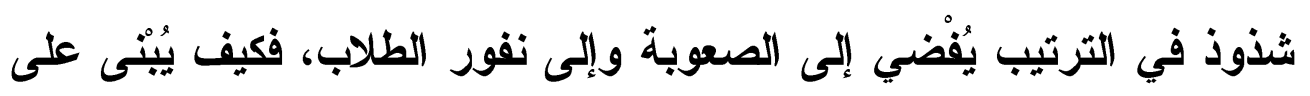

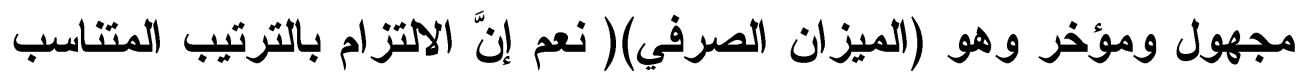

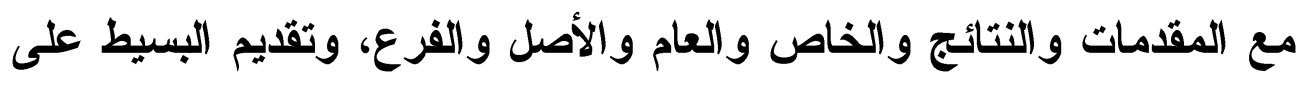

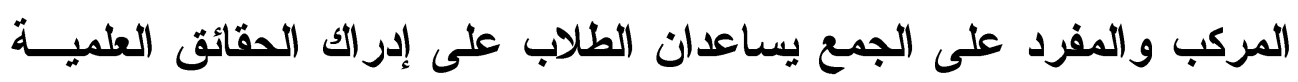

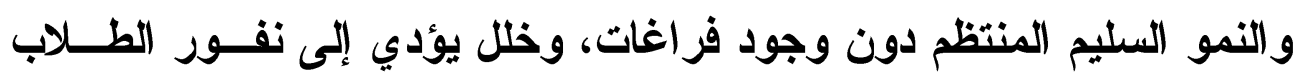

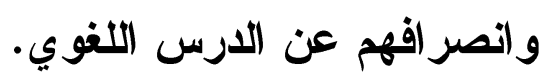

خامسًا: وفي سياق حديثهم عن التوابع نلحظ تفريقهم بينهـــا تفريقًا

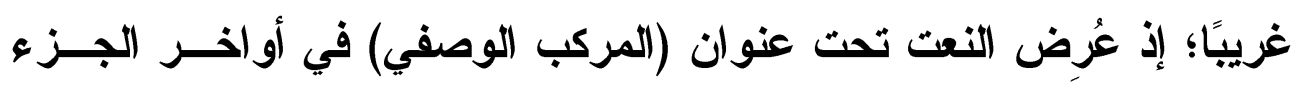

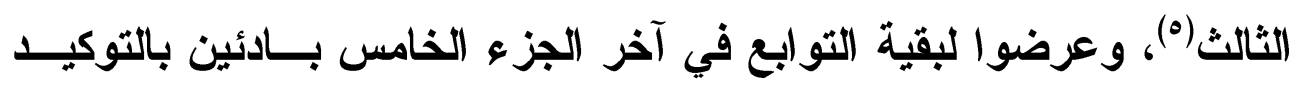

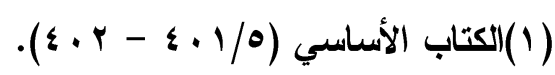

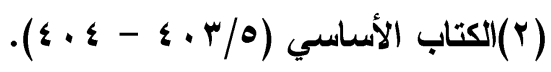

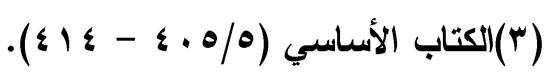

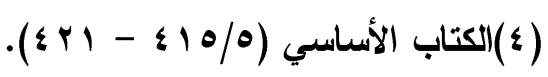

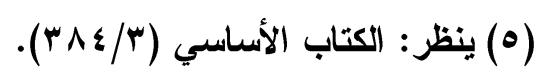




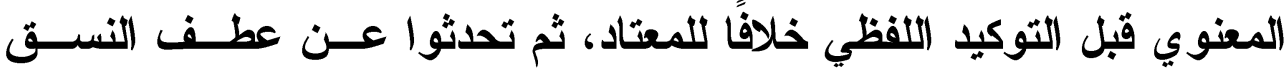

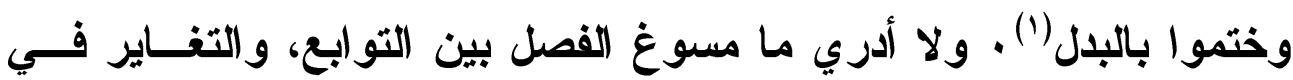

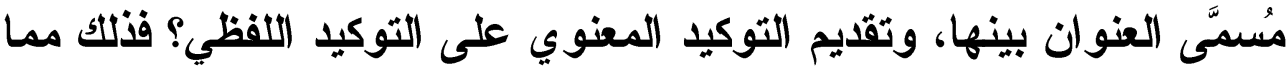
يخالف المنطق وسمات النحو التعليمي، ويثير تساؤلات كثيرة فــي أذهـــان المتعلمين للعربية من غير الناطقين بها.

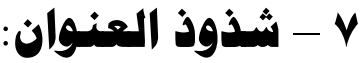

المتصفح لعناوين موضوعات مقرر القواعـــــالنحويــة فـــي الكتـــاب

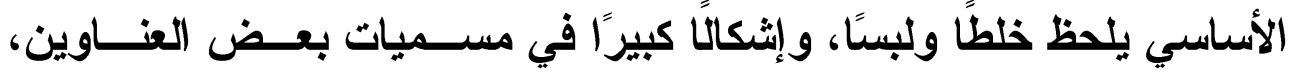

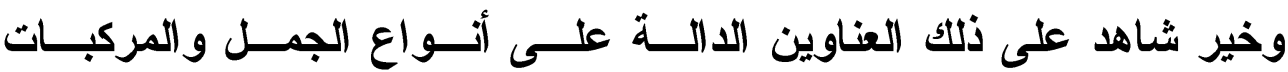

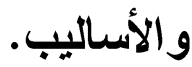

أما العناوين الدالة على أنواع من الجمل العربية، فقد اختار المؤلفون

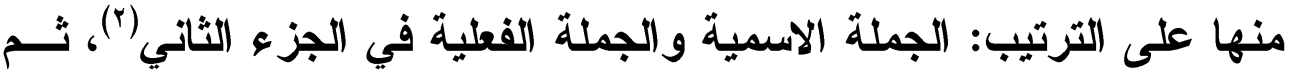
الجملة الاستفهامية، والجملة المنفية، وجملة الأمر، وجملة الصلة، وجملـــة الصنة

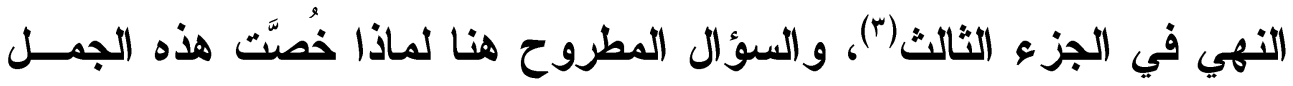
بالأكر دون غيرها كالجملة المثبتة؟

وأما العناوين الدالة على المركبات الاسمية، فقد ذكر المؤلفون منهــا

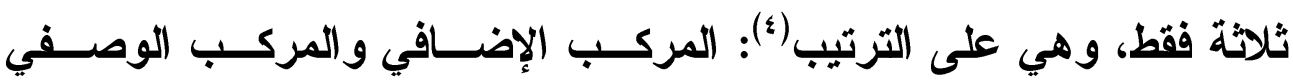

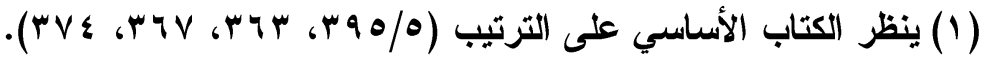

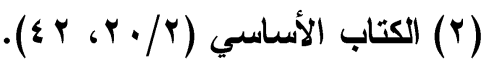

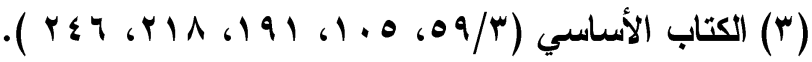

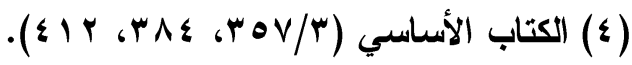


والمركب العددي في الجزء الثالث ، وفي هذا الســياق تبــدو عـدة أســئلة

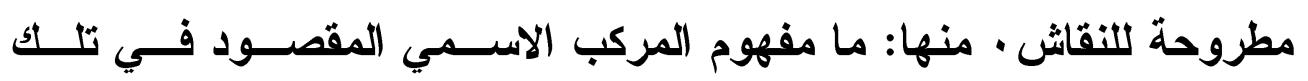

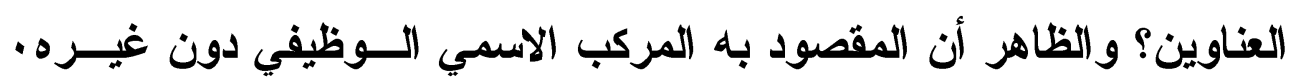
وَمِن العجيب أنَّ المؤلفين اكتفوا بالعنوان فقط في المركب الوصفي والمركب المب المبن

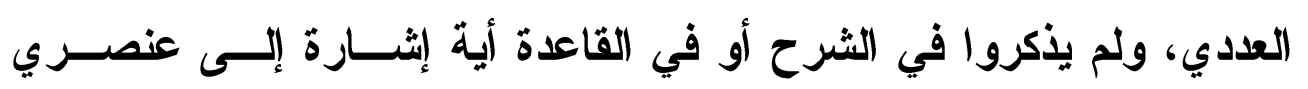

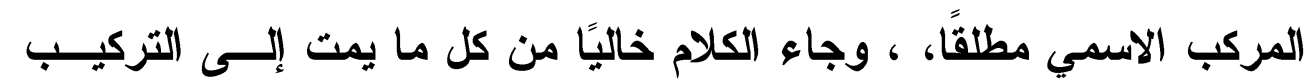
بصلة، واكتفى المؤلفون في موضوع (المركب الإضافي) بالإشارة إلـى أنَّ

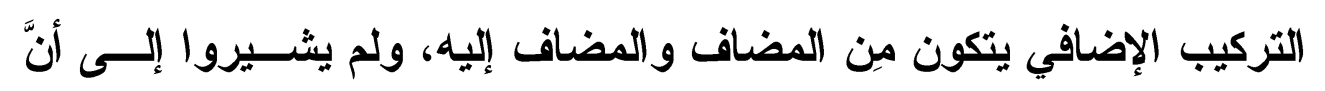
المركب الإضافي مركب اسمي يؤدي وظيفة واحدة في الكلام العربي، وغاب عنهم طرد العناوين على وتيرة واحدة في بقية المركبات الاسمية الوظيفيـة

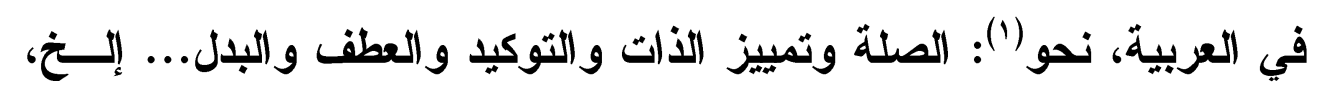
وكان الأجدر بهم وَسنم تلثك الموضوعات بالمركـب الموصــولي، والمركـبـ التمييزي، والمركب التوكيدي، والمركب العطفي، والمركب البدلي ... إلخ . طردًا للعناوين في النظائر المشابهة على وتيرة واحدة.

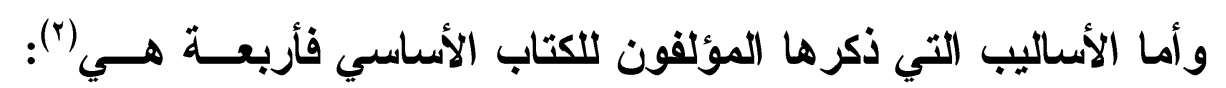
أسلوب التعجب، وأسلوب المدح والأم، وأسلوب الإغراء والتحذير، وأسلوب الاختصاص، وغفل المؤلفون عن أسـاليب أخرى كثيــرة الاســتـعمال: نحــو الاستثناء، حيث تم تناوله وفق أدوات الاستثناء وأثزها الإعر ابي مع التركيز

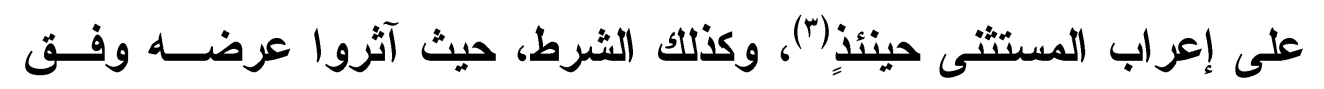

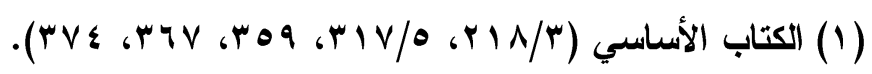

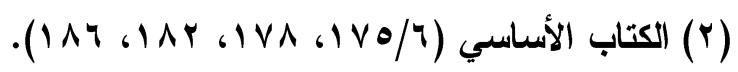
( الكتاب الأساسي (r) ( $)$ 
نظرية العامل، ووفق تقسيم أدوات الثرط إلى جازمة وأخرى غير جازمسـة،

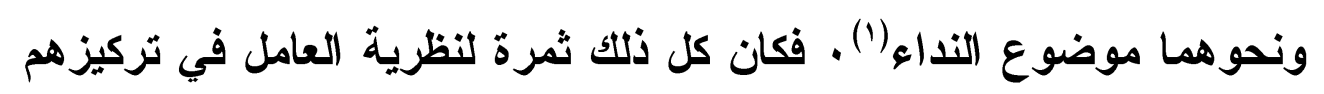

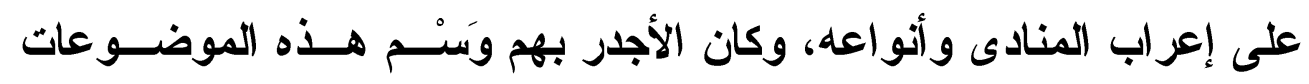

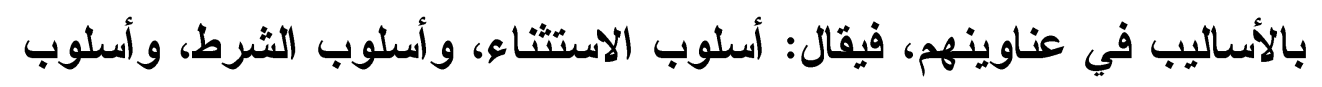

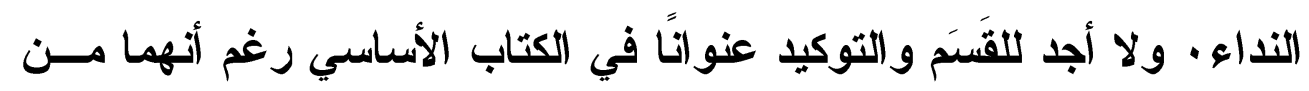
الأساليب الكثيرة الدوران في الأسلوب العربي.

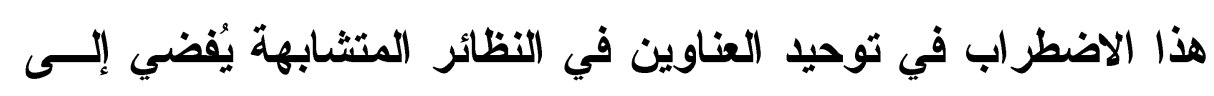
لبس وإثكال كبيرين في أذهان الطلاب غير الناطقين بالعربية، ويمثل مُشكئًا

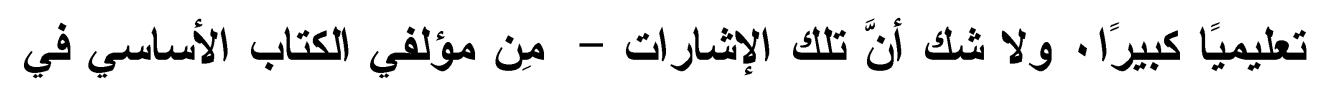
اختيار بعض العناوين للجمل والمركبات الاسمية والأساليب العربية - دليل

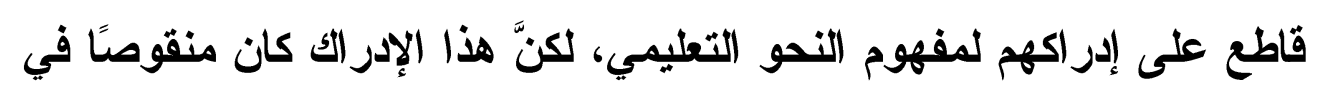

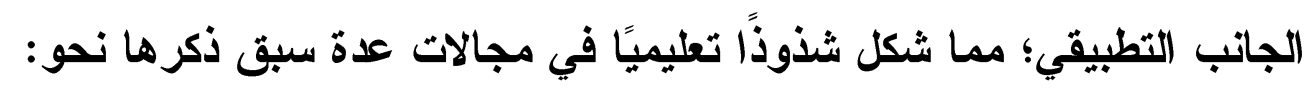

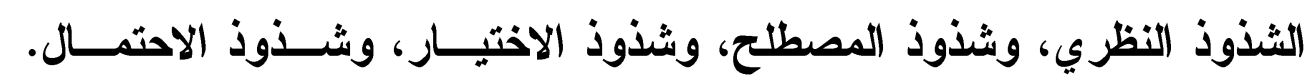

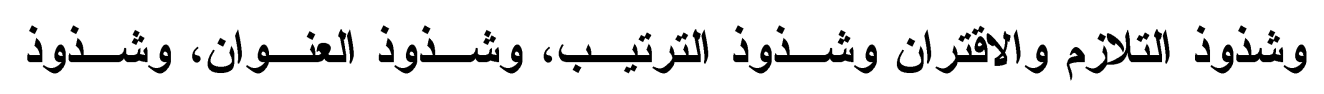
التدريبات... إلخ. ^ - شذوذ المثال النحوي:

مما يُحمْد في الكتاب الأساسي حرص المؤلفين على أن يكون المثــال

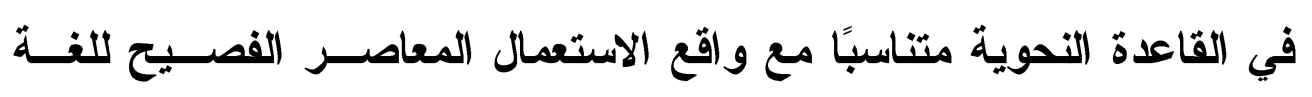

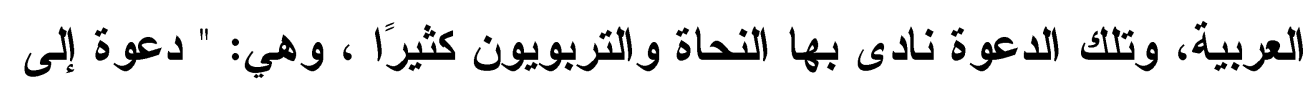

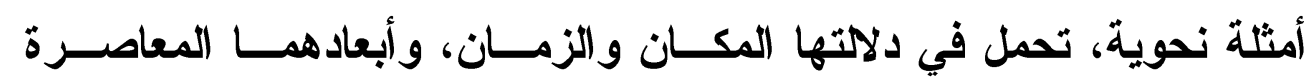




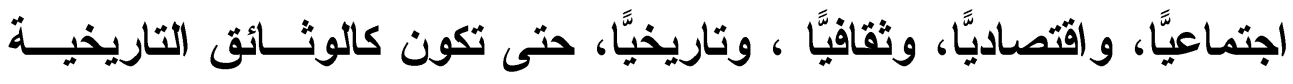

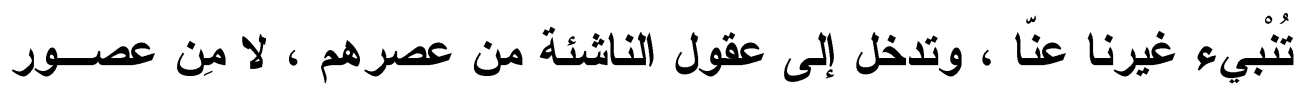

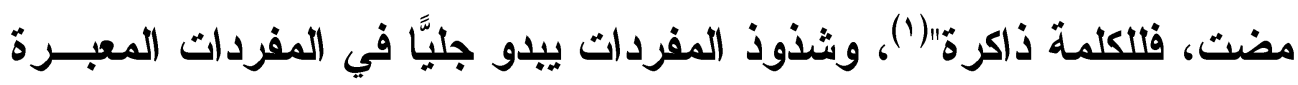

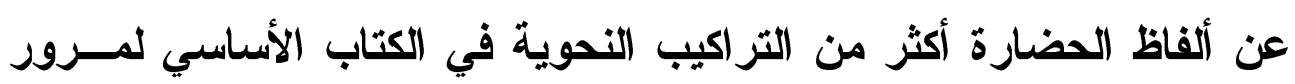

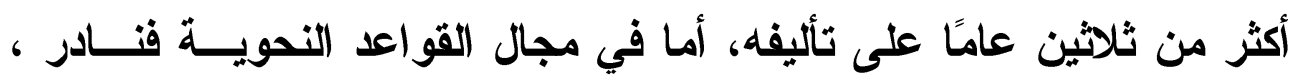

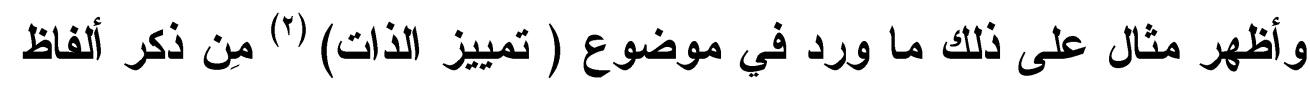

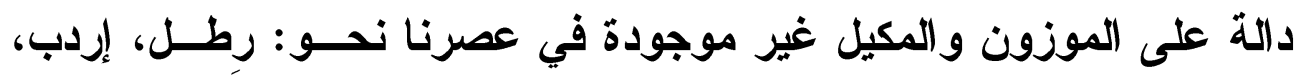

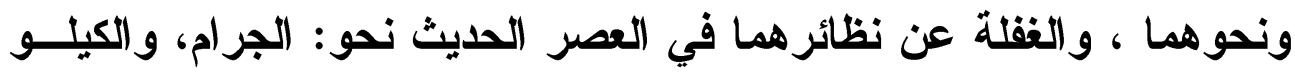

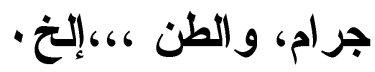

\section{9 - و شذوذ التدريبات:}

أجمع العلماء على وجوب تحقيق المناسبة بين التـــريبات والقاعــــة

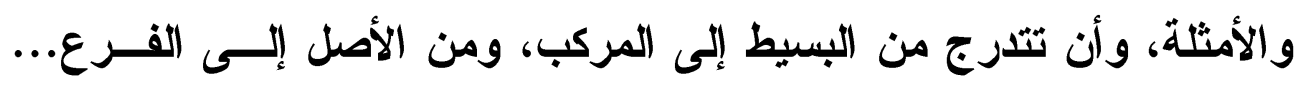

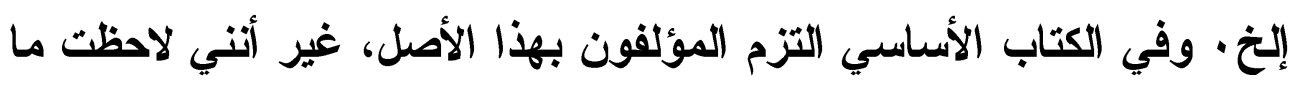

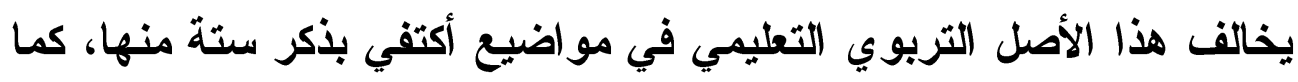
يلي:

الموضوع الأول: في (المفعول المطلق) (ז) اكتفى المؤلفون بـالتعريف

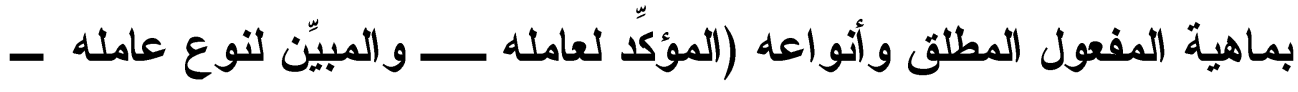

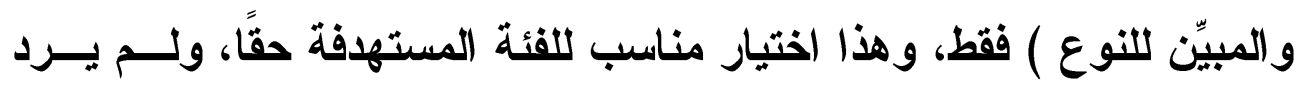
ذكر للنائب عن المفعول المطلق، إلا أن التدريبات ورد فيها ثلاث آيات تدور

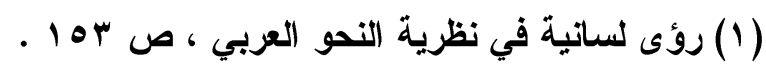

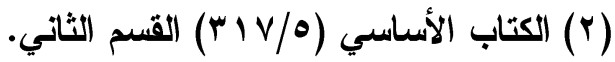

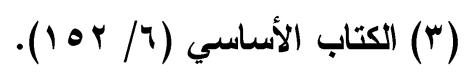




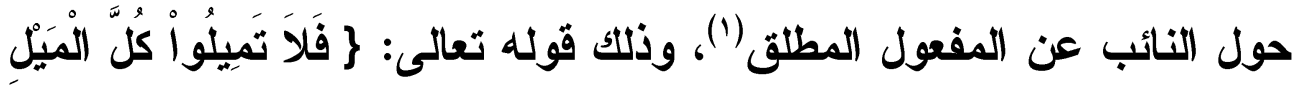

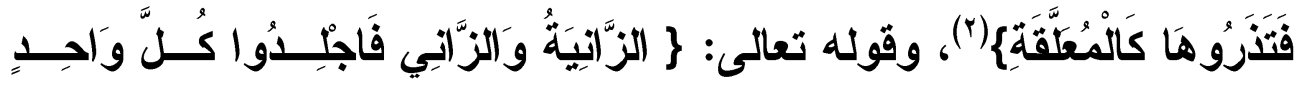

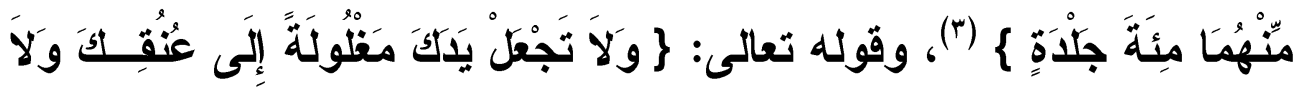

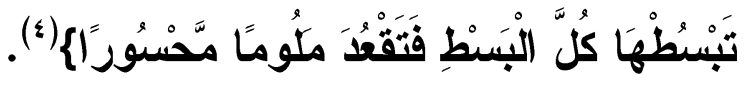

الموضوع الثاني: في (البدل) (o)، ذكر المؤلفون ضرورة وجود رابـط في بلل البعض من كل، وبدل الاشتمال في قولهم: "بدل البعض مــن الكـلـل

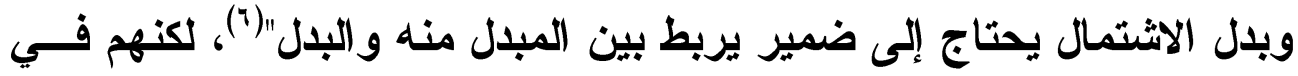
التدريبات اختاروا آية كريمة وطلبوا إعرابها وبيان البدل في قوله تعسالى:

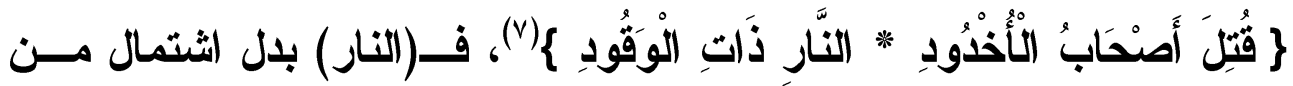

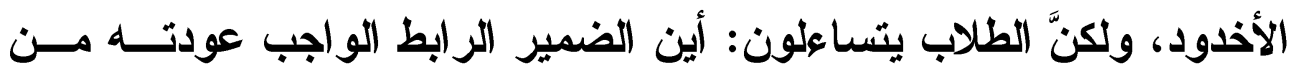

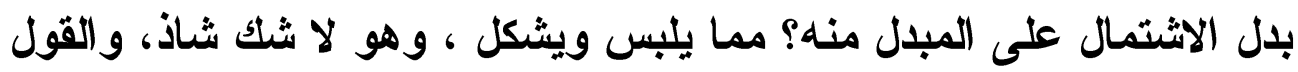
فيه على وجهين (^) الأنمال أولهما: الرابط محذوف متصل بغير البذل، والتقدير (والنار فيه) وهـو

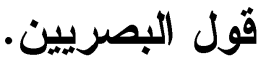

و اللوجه الثاني: أنه لا تقدير هنــا، والأصـل (نــاره) ثـــم نابــــ (ال)

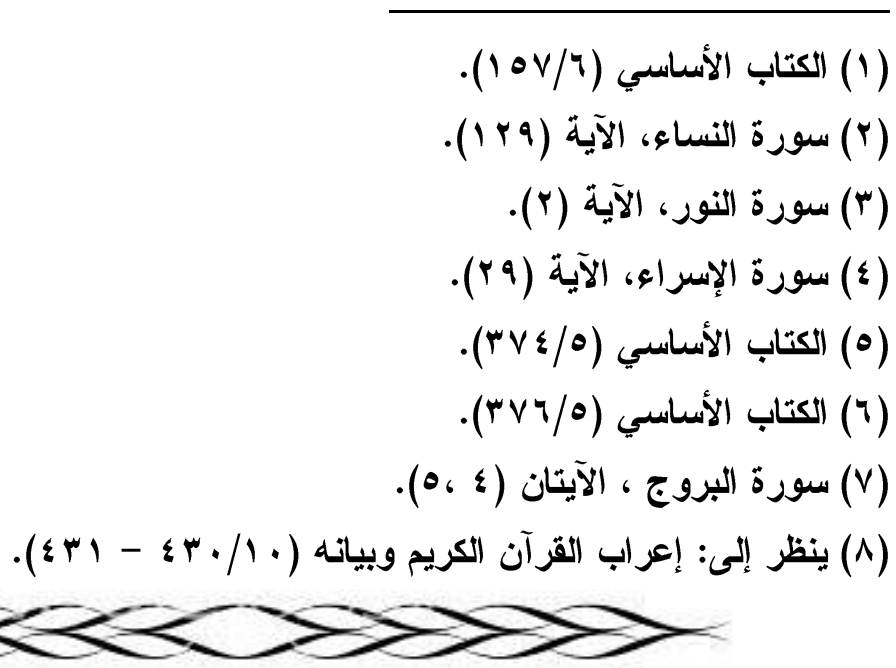


التعريفية عن الضمير، وهو قول الكوفين.

الموضوع الثالث: في (اسم الفاعل) (') حيث ورد سؤال ملّبس يمثــل إثكالاً كبيزًا لاى الطلاب غير الناطقين بالعربية، هذا الإثكال لَمَســته فــي

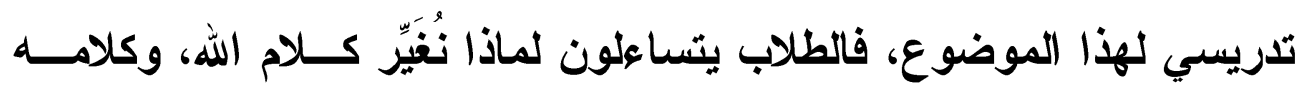
الأفصح! ولا داعي لتدريب الطلاب على تغيير آي الأكر الحكـيـم، والســؤال

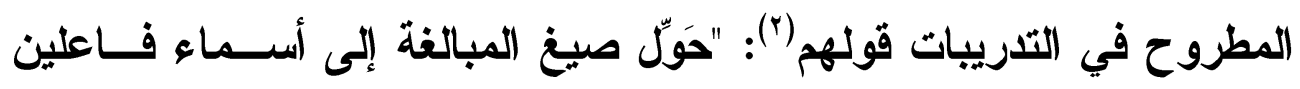
وَبَيِّن أفعالها وضعها في جملة مفيدة": ثم أردف المؤلفــون هــــا الســؤال بخمس جمل، أربعة منها آيات كريمة، ومثال واحد من كلامهم، وتثلك الآيات

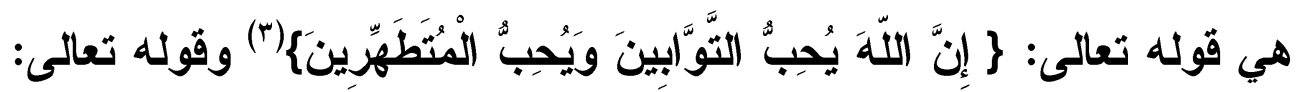

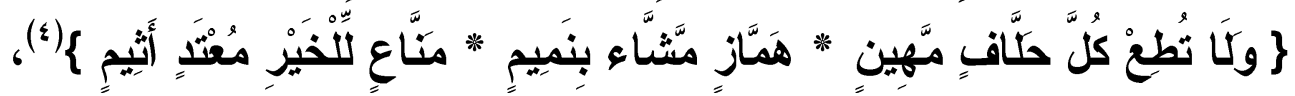

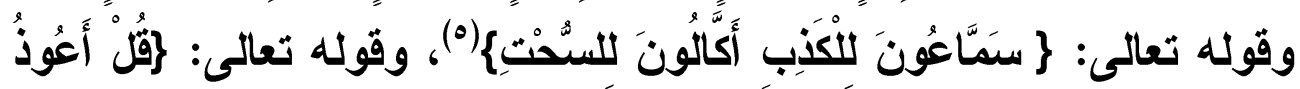

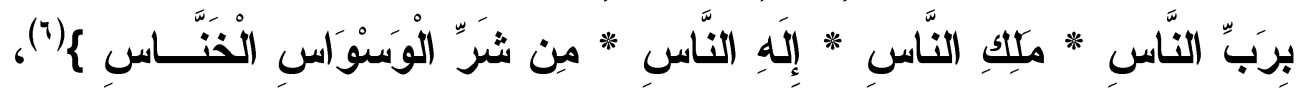

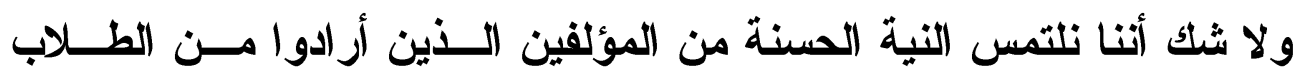
المقارنة بين أفصح كلام وكلام البشر، لكنَّ الطلاب ليسوا في موقف تعليمي

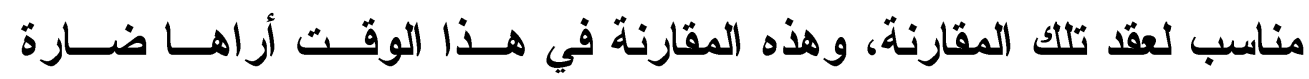
تعليمية، فتلك المقارنة قد تؤتي ثمارًا سلبية لايهم بخلاف المقصود . .

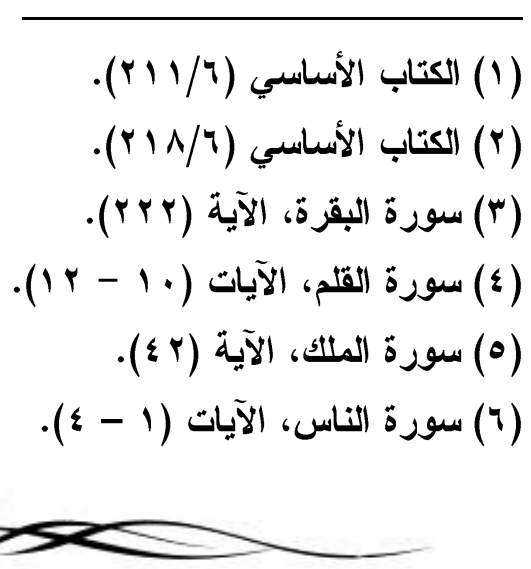


الموضوع الرابع: في (الحال) (') حيث طلب المؤلفون تعيـين الحسال

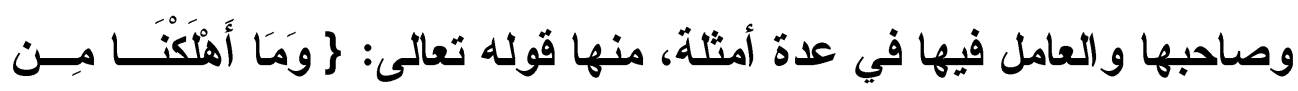

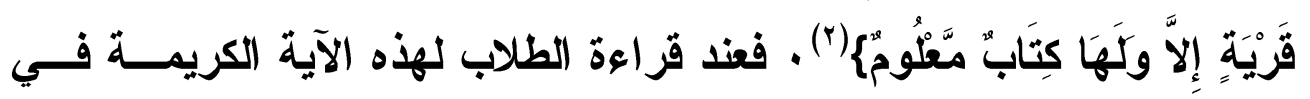

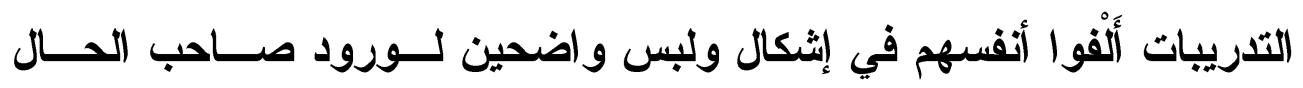

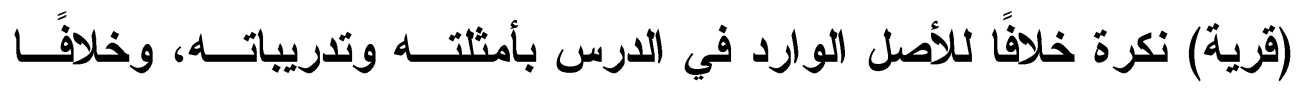

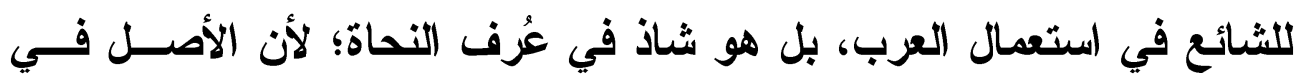

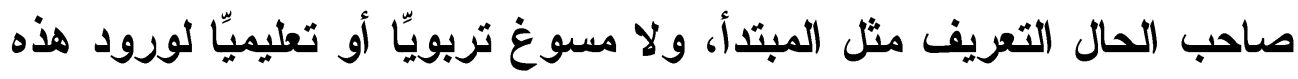

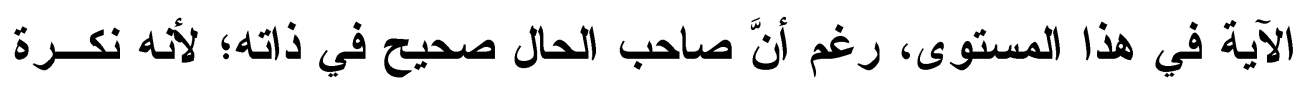

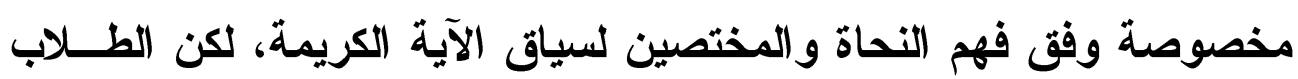

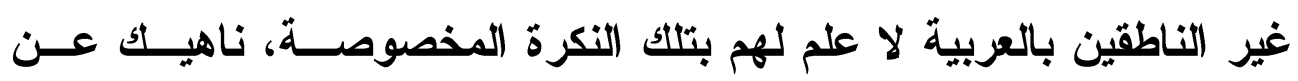
إلز امهم بتعيين العامل في الحال في التدريبات.

الموضوع الخامس: في (لا) النافية للجنس (")، حيــث أورد المؤلفـــون

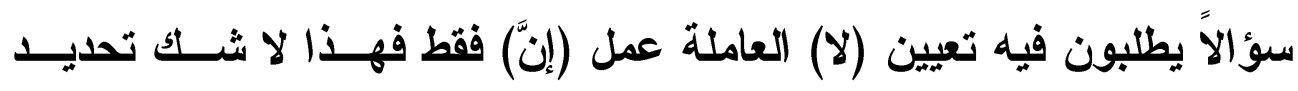
مقصود ، ولم يُطلب فيه إعراب اسم (لا) النافية للجنس لعلمهم بتعدد الأوجه

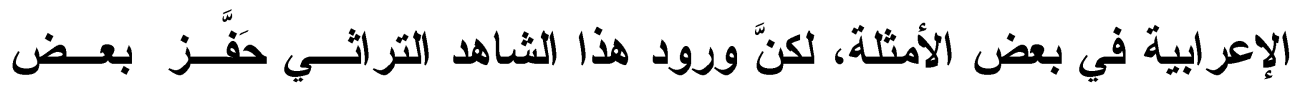

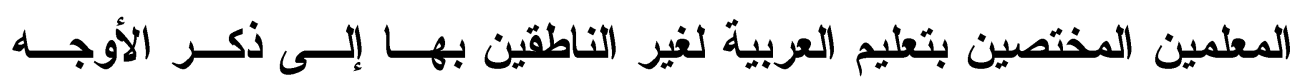
الإعرابية المحتملة في إعراب (لا حول ولا قوة إلا بالله) وأضاف إليه نظائره

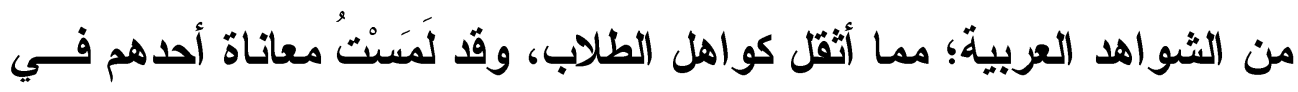

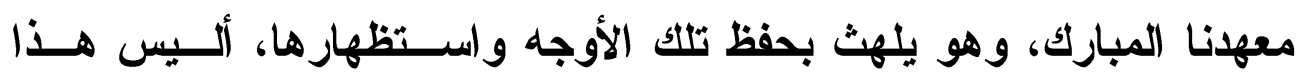

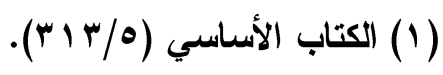

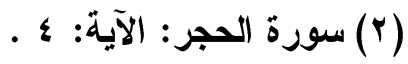

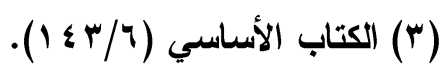




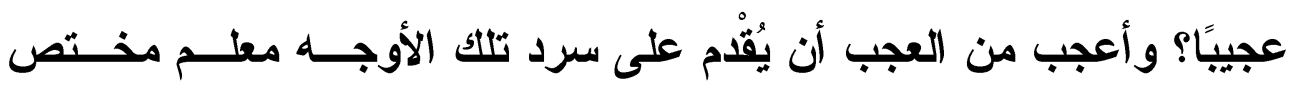
بتعليم العربية لغير الناطقين بها ، ولم يقم بهذا الثذوذ معلم من المختصين

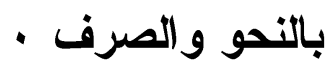
الموضوع السادس: في ( عطف النســق) (')، حيـث أورد المؤلقــون قولهم : الكلمة: اسم أو فعل أو حرف + ثم طلبوا منهم تعيين حرف العطـف ودلالته، ودلاكة (أو) في هذا الموضع هي:( التقسيم) وليست هــذه الدلاحــة واحدة من الالالات الثلاثة المذكورة في موضوع الارس وهـي: ( الثـــك، والإباحة ، و التخييز) فقط من 


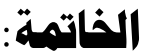

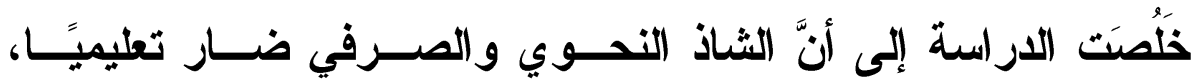

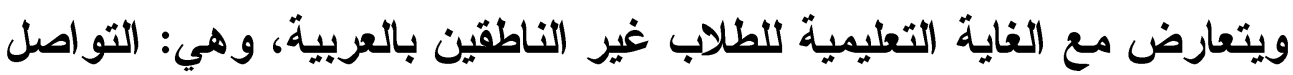

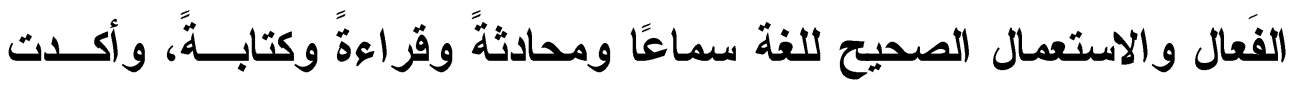
الاراسة أن مكان الثاذ بنوعيه: النحو العلمي لا النحو التعليمي، ومن خلال

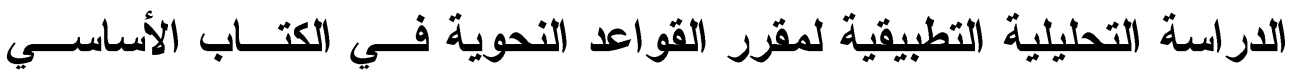
رصدت تسعة أنواع من الثذوذ، هي : (الثذوذ النظري - شذوذ المصطلح

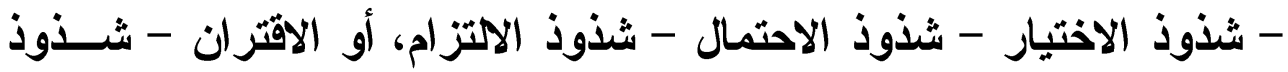

$$
\text { الترتيب - شذوذ العنوان - شذوذ المثال - شذوذ التدريبات ) }
$$

ودعت الاراسة إلى التمييز بين الغرض مين وضع النـــو، وطريقــة

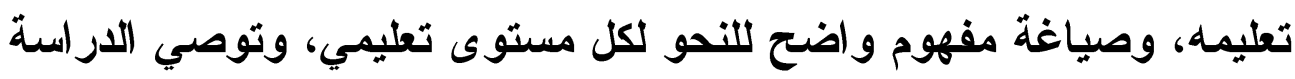

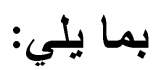

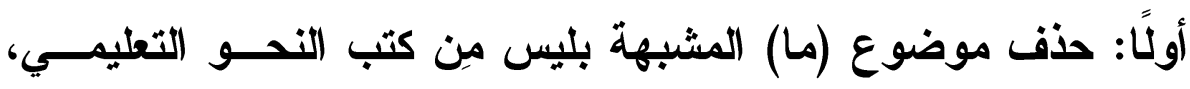

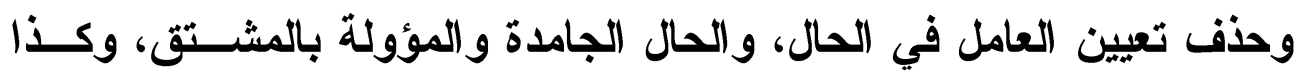
تعيين الر ابط في الخبر شبه الجملة، وتجنب خلافات النحاة في جمود (ليس)

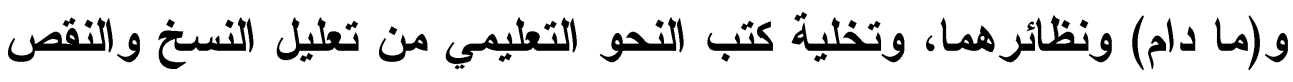

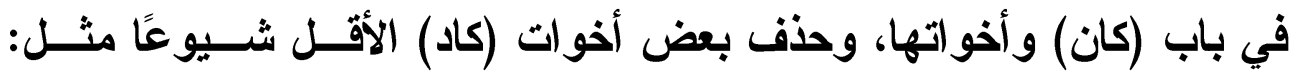

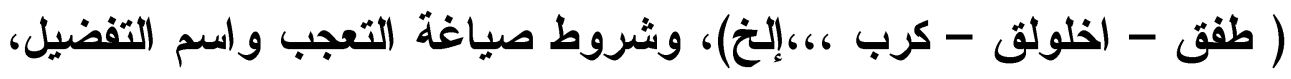

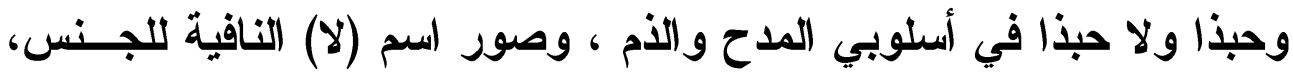

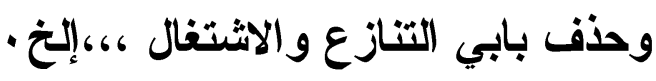


ثانيًا: تَبَّبِّ توجيه صرفي واحد في مسألة الحذف في الميزان الصرفي

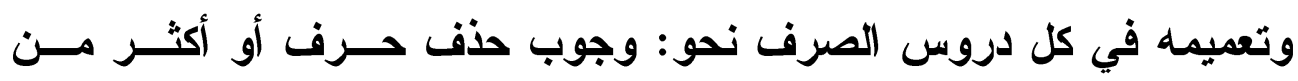

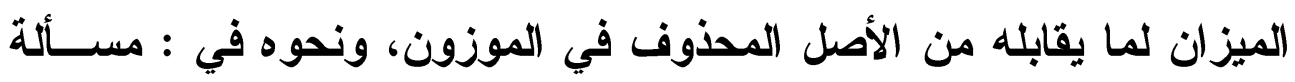

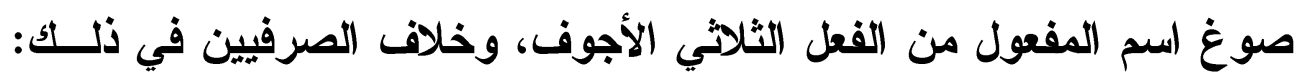

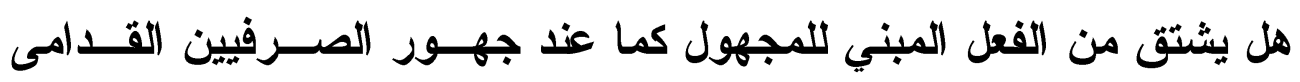

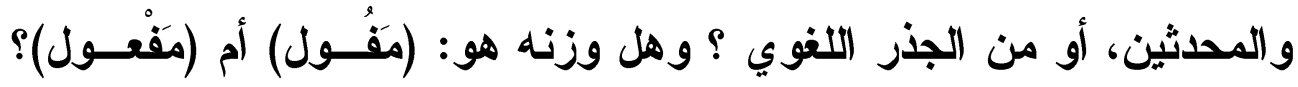

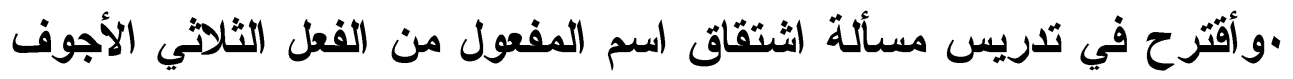

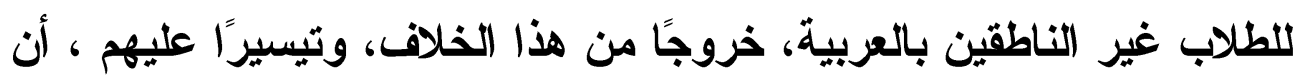

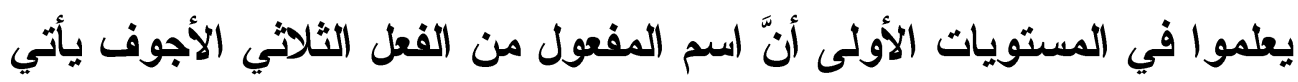

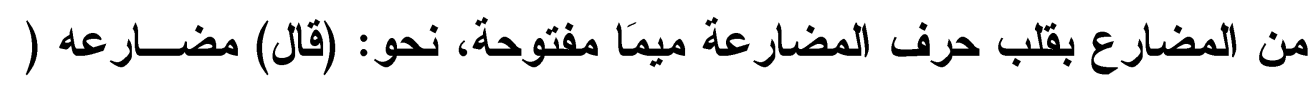

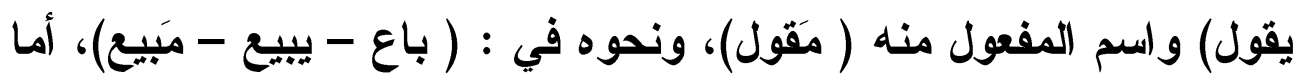

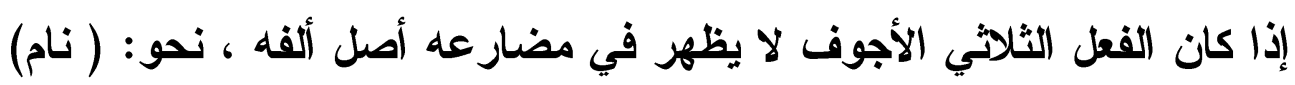

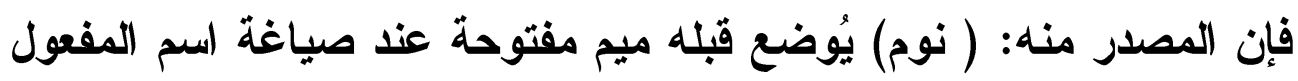

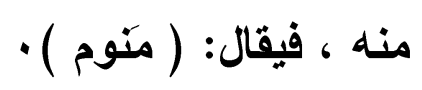

ثالثًا: الدعوة إلى توحيد المصطلح فــي الكتــاب التعليمـي، واختيــار

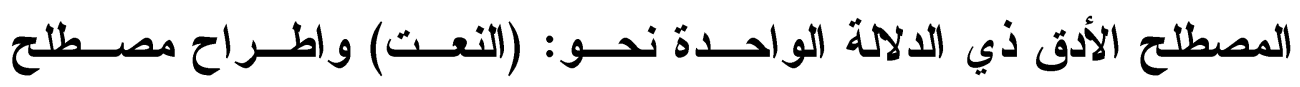
(الوصف) في باب التوابع، وتجنب المصطلحات الغامضة والنادرة الاستعمال

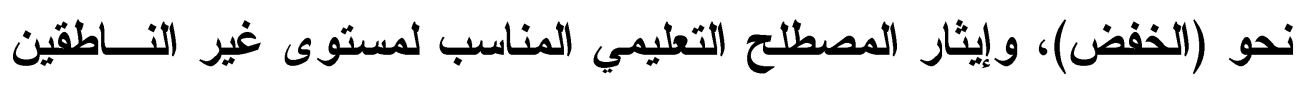

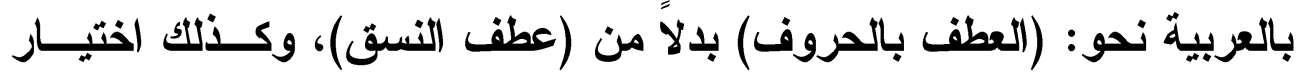

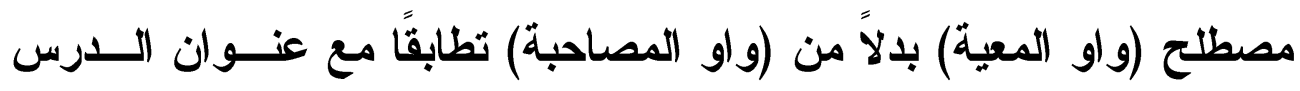
(المفعول معه). (اول) 
رابعًا: التزام المنهج العلمي في اختيار الموضــوعات لكــل مســتوى تعليمي، فيجب حذف موضوع (الاثنغال) لقيامه على التعليل وخلافات النحاة

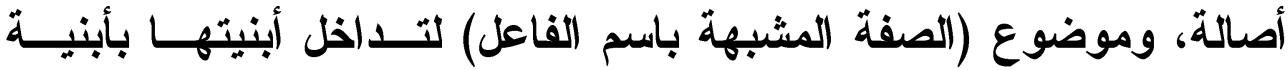
صرفية أخرى، وفي ثنايا الاروس يجب عدم شرح الموضوع إلا عند اكتمال تعريف الطلاب بكل عناصره.

خامسًا: حذف كل ما يتطرق إليه احتمال إعر ابــي أو صــرفي مغــاير للمنهج المقرر لكل مستوى تعليمي، وأظهر مثال لذلك أبنية (الصفة المشبهة باسم (الفاعل).

سادسًا: اعتماد منهج واحد في اختيار عناوين الموضوعات في الكتب التعليمية، في سياق المركبات والأساليب العربية، وأَبيَنْ مثال لذلك إطلاقهـــ مصطلح (المركب الوصفي) على النعت، وعرض بقيــة التوابــع بعنـاوين

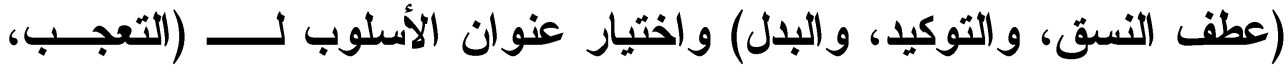
و الاختصاص، والمدح والأم، والإغـــراء و التحـــير) دون بقــــة الأســاليب العربية، نحو: الاستثناء، والشرط، والنداء، والقسم، والتوكيد... إلخ. سابعًا: اختيار التدريبات وبناؤها على نحو مناسب لمحتــوى الــــرس وللطلاب غير الناطقين بالعربية، ولعُمْزهم وإدراكهم العقلي.

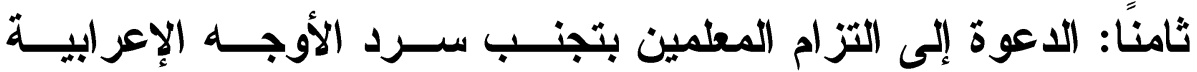
المحتملة، وإلزام الطلاب بها في الاختبار، وتجنب التوسع في المادة العلمية بشرح موضوعات غير مقررة، أو جزئيات مطروحة من الارس التعليمسي، ونأمل تثقية الكتب التعليمية من تلكاك الثواهد المخالفـــة الأسـسس التربويـــة والتعليمية في تعليم العزبية لغير الناطقين بها. •وأخيرًا آمل العمل بهذه التوصيات في تأليف الكتب التعليمية. 


\section{المادر والمراجع :}

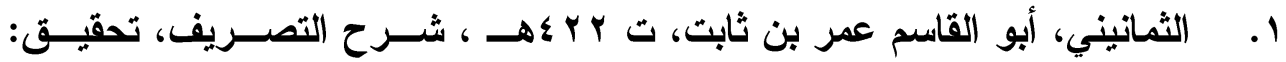
إبر اهيم بن سليمان البعيمي ط. الأولى، مكتبة الرشد، الرياض، (999 (99) إم).

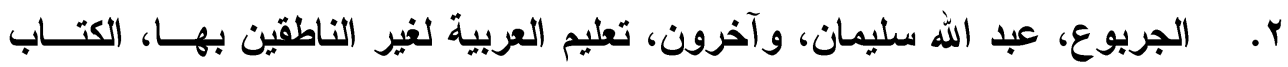

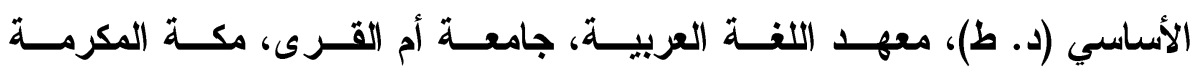
.(م) $9 \wedge \varepsilon)$ )

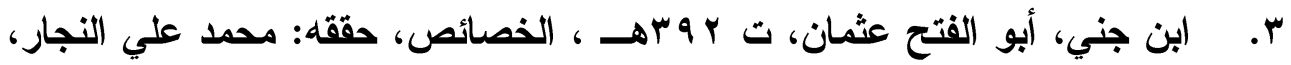

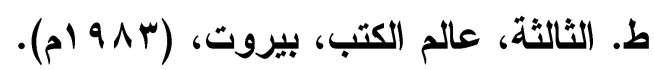

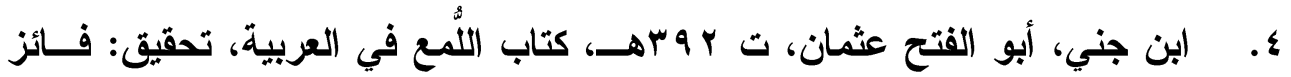

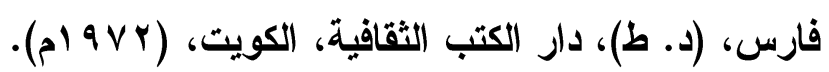

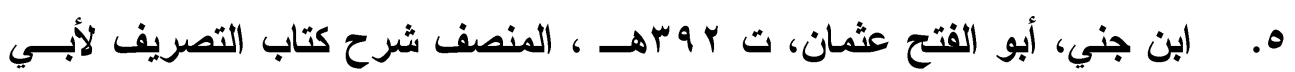

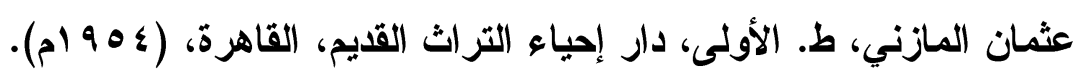

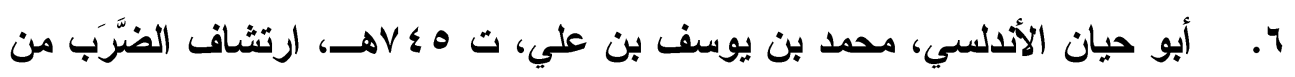

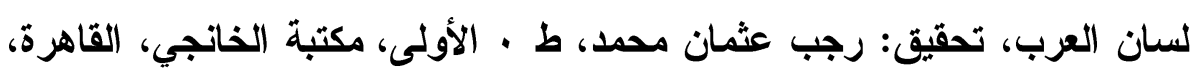
.(م) (991)

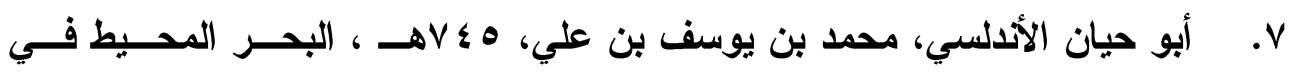

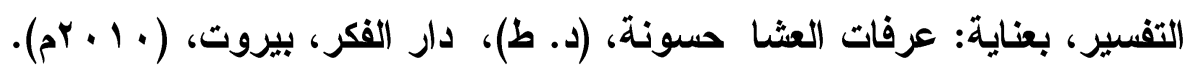

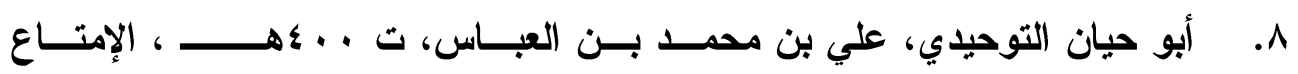

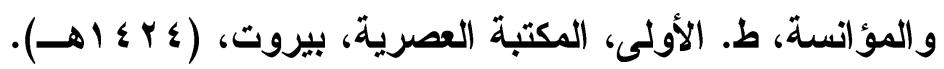

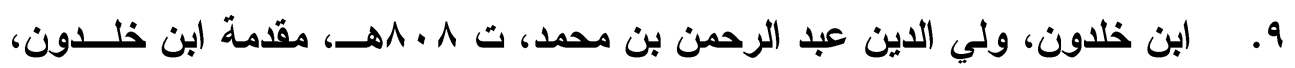

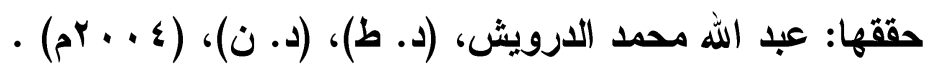

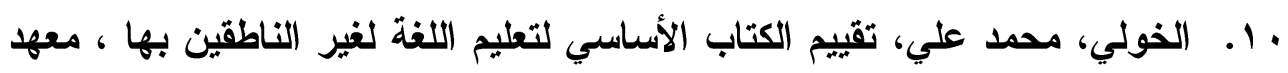

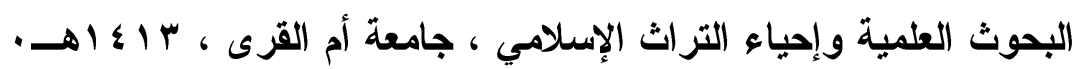

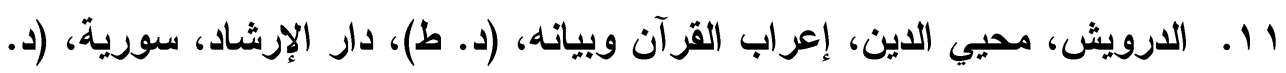

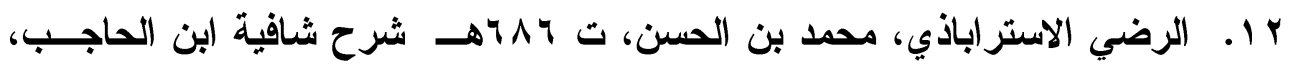


حققها: محمد نور الحسـن وآخــرون، (د. ط)، دار الكتــب العلميـة، بيــروت،

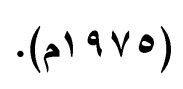

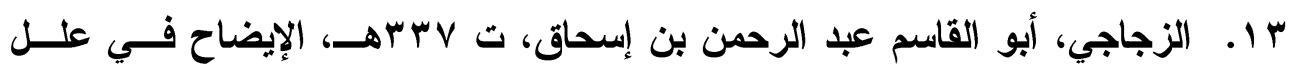

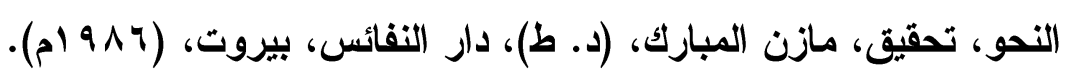

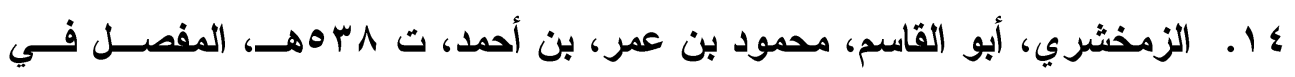

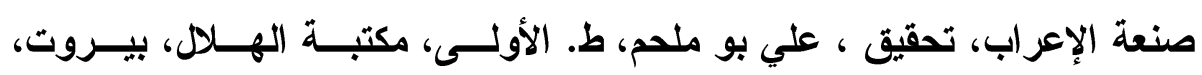

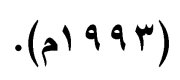

ه ا. ابن السراج، أبو بكر محمد بن سهل، ت 7 ابهـ، الأصول في النحو، تحقيـق:

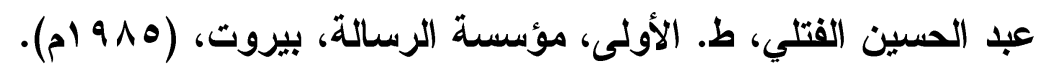

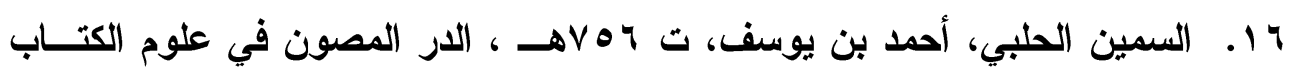
المكنون، تحقيق: أحمد محمد الخراط، (د. ط)، دار القلم، دمثق، (د. تـ).

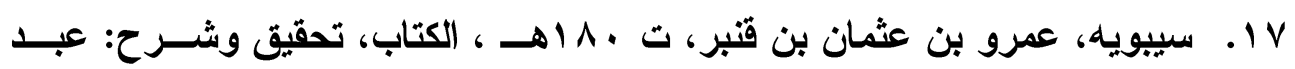

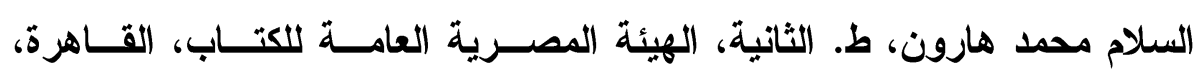
. (م) $9 \vee V)$

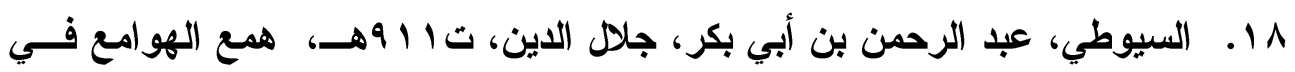

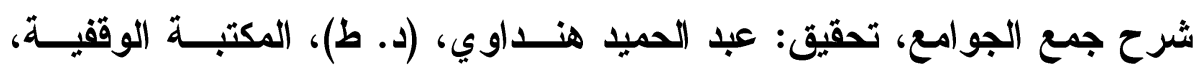

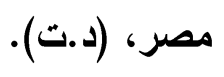

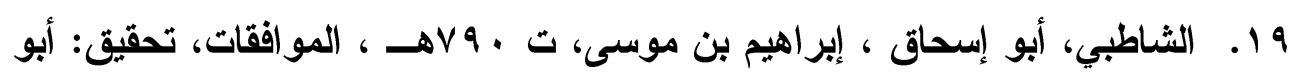

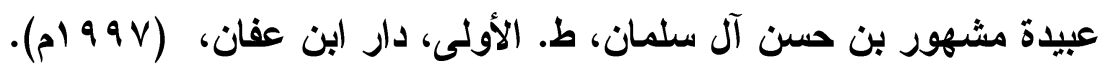

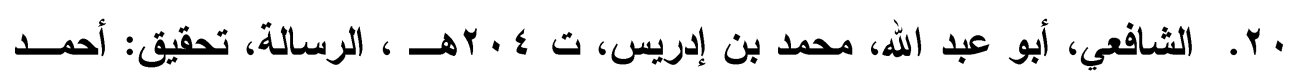

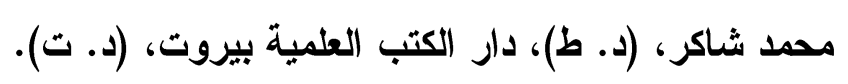

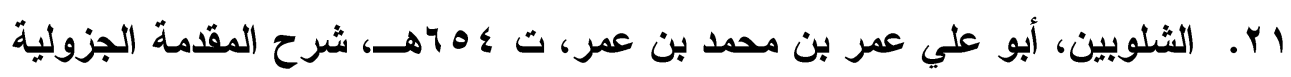

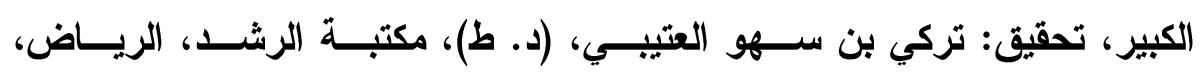

$$
\text { . (أمبان) }
$$

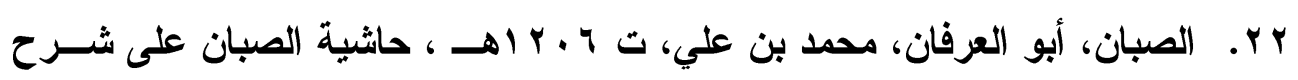
الأشموني لألفية (بن مالك، ط. الأولى، دار الكتب العلمية، بيروت، (V9 9 ام). 
r r . عبابنة، يحيى عطية، تظور المصطلح النحوي البصـري مــن سـيبويه حتـى

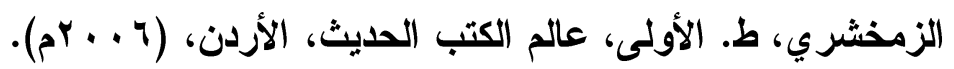

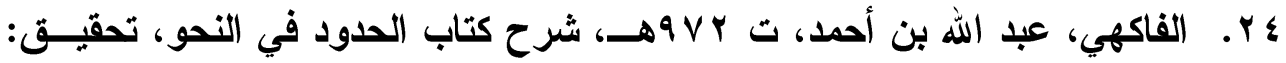

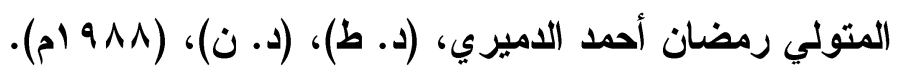

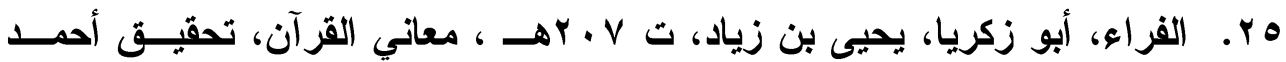

$$
\text { يوسف النجاتي وآخرين، (د. ط)، (د. ن)، (د. تـ ند). }
$$

דr. الفوزان، عبد الرحمن بن إبراهيم، وآخرون، العربية بين يديك ، كتاب الطالب(1)

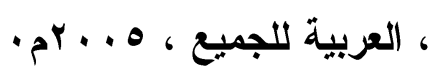

rV

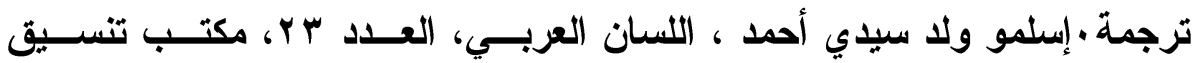

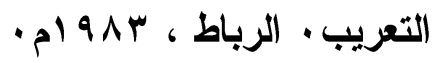

^ץ. الماحي، محمد عبد النور محمد ، معايير اختيار التراكيب النحوية في كتب تعلـيم اللفة العربية للناطقين بغيها ـ دراسة تطبيقية على كتاب الطالــب مــن سلســلة العربية بين يديك ، مجلة العلوم الإنسانية، جامعة السودان للعلوم والتكنولوجيا ،

$$
\text { مج }
$$

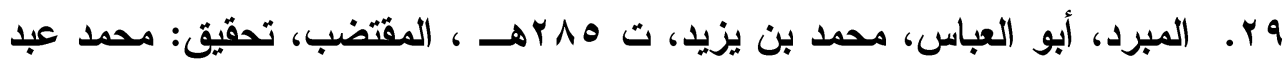
الخالق عضيمة، (د. ط)، المجلس الأعلى للشؤون الإسلامية، مصر، (ع 9 9 ام).

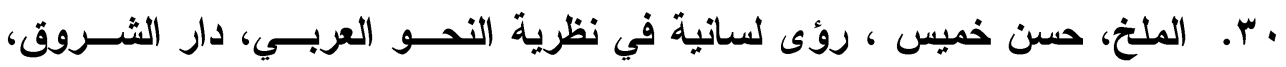

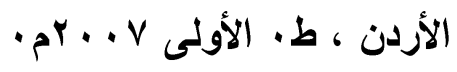

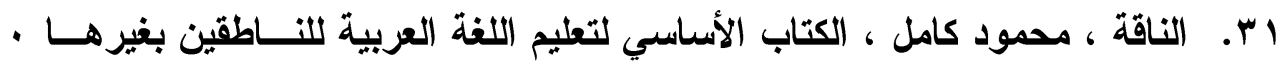

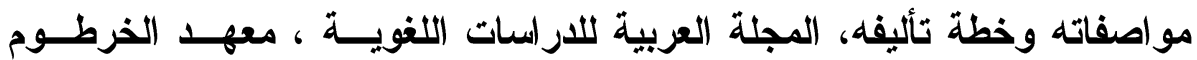

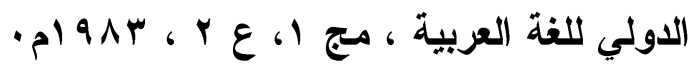

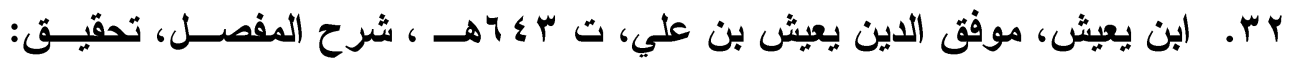

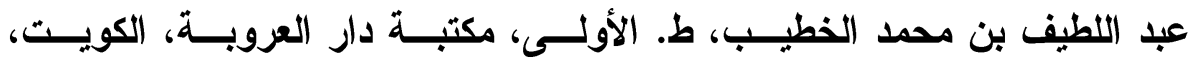



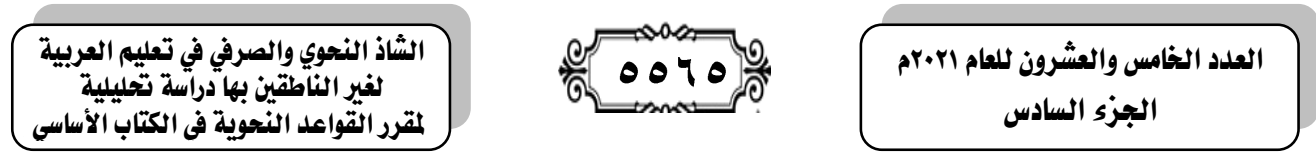

\section{فهرس الموضوعات}

\begin{tabular}{|c|c|c|}
\hline |لصنمة & الإوضَوعَع & 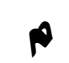 \\
\hline $00 \cdot V$ & هلخص & .1 \\
\hline $00 \cdot 1$ & Abstract & $r$ \\
\hline 00.9 & الاقد همة & $r$ \\
\hline $001 \varepsilon$ & أولاً : كتاب (تعليم العربية لغير الناطقين بها) .(الكتاب الأساسي) : &.$\xi$ \\
\hline DOIV & ثانياً : هاهية الندو المقدم لغير الناطقين بالعربية ووظيفته: & .0 \\
\hline oOr. & 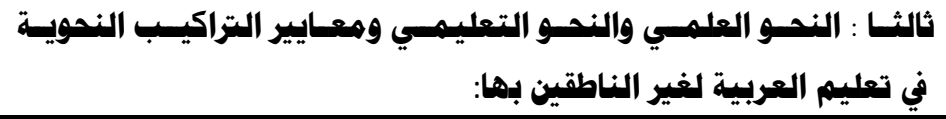 & .7 \\
\hline OOYE & رابعا : الشاذ النحوي والصرفي تعليميسا: & 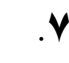 \\
\hline OOYA & هخطط الشاذ النهوي والصرفي في الكتاب الأساسي &.$\hat{~}$ \\
\hline OOYA & 1. الشذوذ النظري (الصناعي): & .9 \\
\hline oors & r. شذوذ الصطاح: & 1 \\
\hline oora & 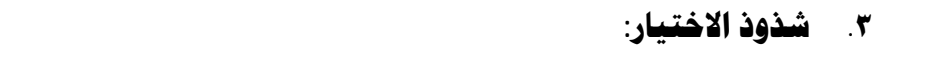 & .11 \\
\hline $00 \leqslant r$ & 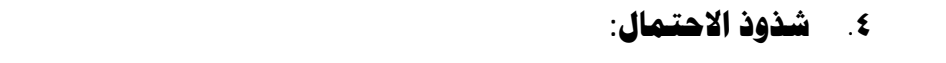 & $.1 r$ \\
\hline $00 \leqslant 0$ & 0. شذوذ التلازم والاقتران: & (r \\
\hline $00 \leqslant 7$ & 1. شذوذ الترتيب: & .18 \\
\hline 0001 & ע. شذوذ العنهوان: & .10 \\
\hline ooor & 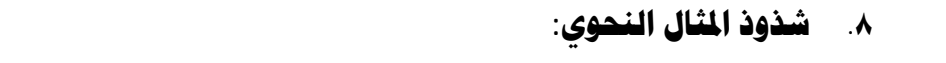 & .17 \\
\hline 000$\}$ & 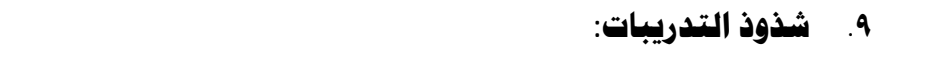 & $.1 \mathrm{~V}$ \\
\hline 0009 & الخاتمة: & .11 \\
\hline $007 r$ & 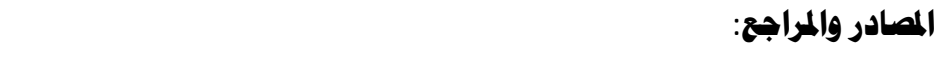 & .19 \\
\hline 0070 & فهرس الموضوعات &.$r$. \\
\hline
\end{tabular}

